\title{
ZUSES
}

Prepared in cooperation with the Oregon Department of Environmental Quality and Deschutes County

\section{Evaluation of Approaches for Managing Nitrate Loading from On-Site Wastewater Systems near La Pine, Oregon}

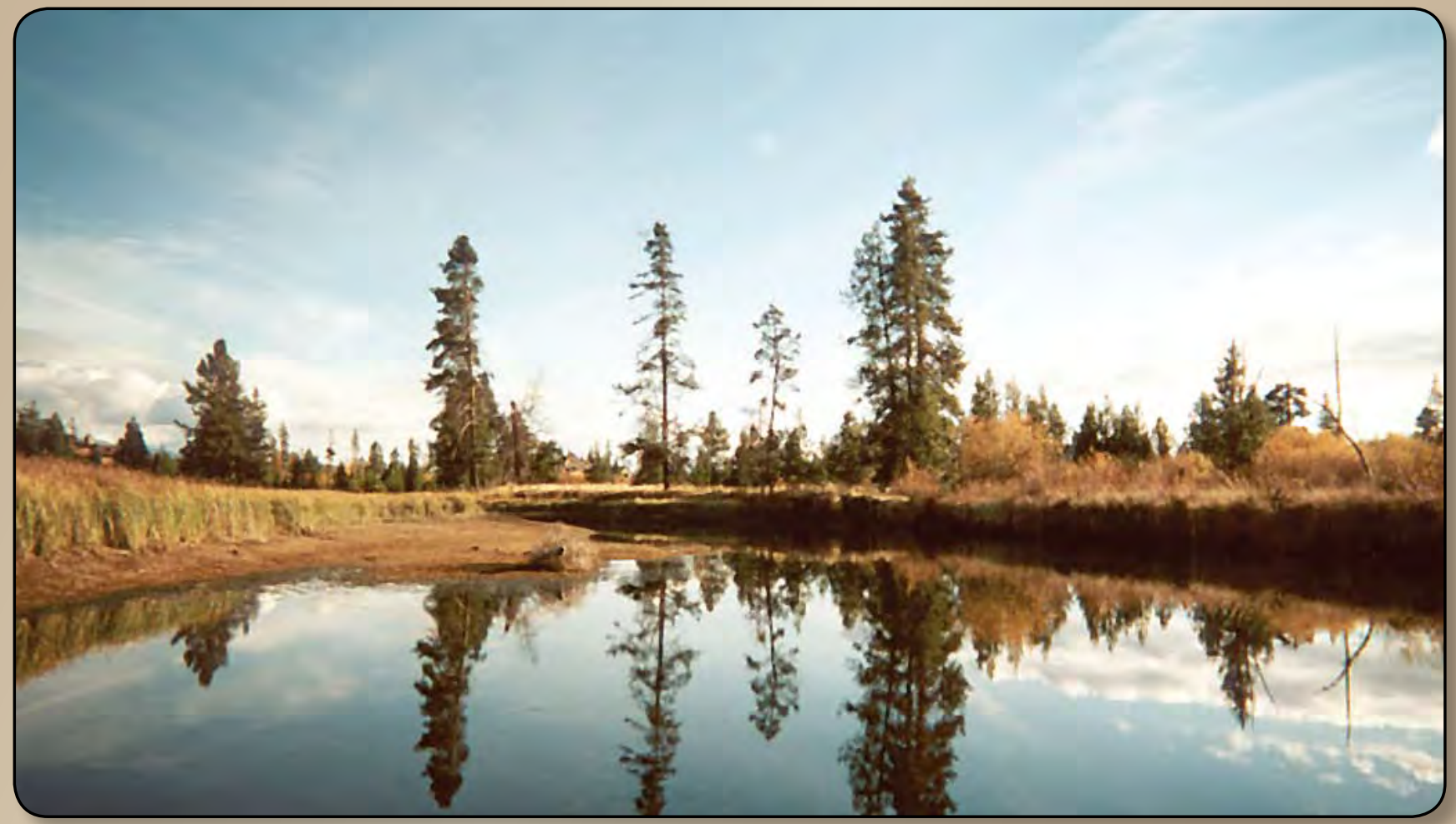

Scientific Investigations Report 2007-5237 
Cover: Photograph of Little Deschutes River near La Pine, Oregon. (Photograph taken by David Morgan, U.S. Geological Survey, 2000.) 


\section{Evaluation of Approaches for Managing Nitrate Loading from On-Site Wastewater Systems near La Pine, Oregon}

By David S. Morgan, Stephen R. Hinkle, U.S. Geological Survey, and

Rodney J. Weick, Oregon Department of Environmental Quality

Prepared in cooperation with the Oregon Department of Environmental Quality and Deschutes County

Scientific Investigations Report 2007-5237 


\title{
U.S. Department of the Interior DIRK KEMPTHORNE, Secretary
}

\author{
U.S. Geological Survey \\ Mark D. Myers, Director
}

\section{U.S. Geological Survey, Reston, Virginia: 2007}

For product and ordering information:World Wide Web: http://www.usgs.gov/pubprod Telephone: 1-888-ASK-USGS

For more information on the USGS - the Federal source for science about the Earth, its natural and living resources, natural hazards, and the environment:

World Wide Web: http://www.usgs.govTelephone: 1-888-ASK-USGS

Any use of trade, product, or firm names is for descriptive purposes only and does not imply endorsement by the U.S. Government.

Although this report is in the public domain, permission must be secured from the individual copyright owners to reproduce any copyrighted materials contained within this report.

Suggested citation:

Morgan, D.S., Hinkle, S.R., and Weick, R.J., 2007, Evaluation of approaches for managing nitrate loading from on-site wastewater systems near La Pine, Oregon: U.S. Geological Survey Scientific Investigations Report 2007-5237, 66 p. 


\section{Contents}

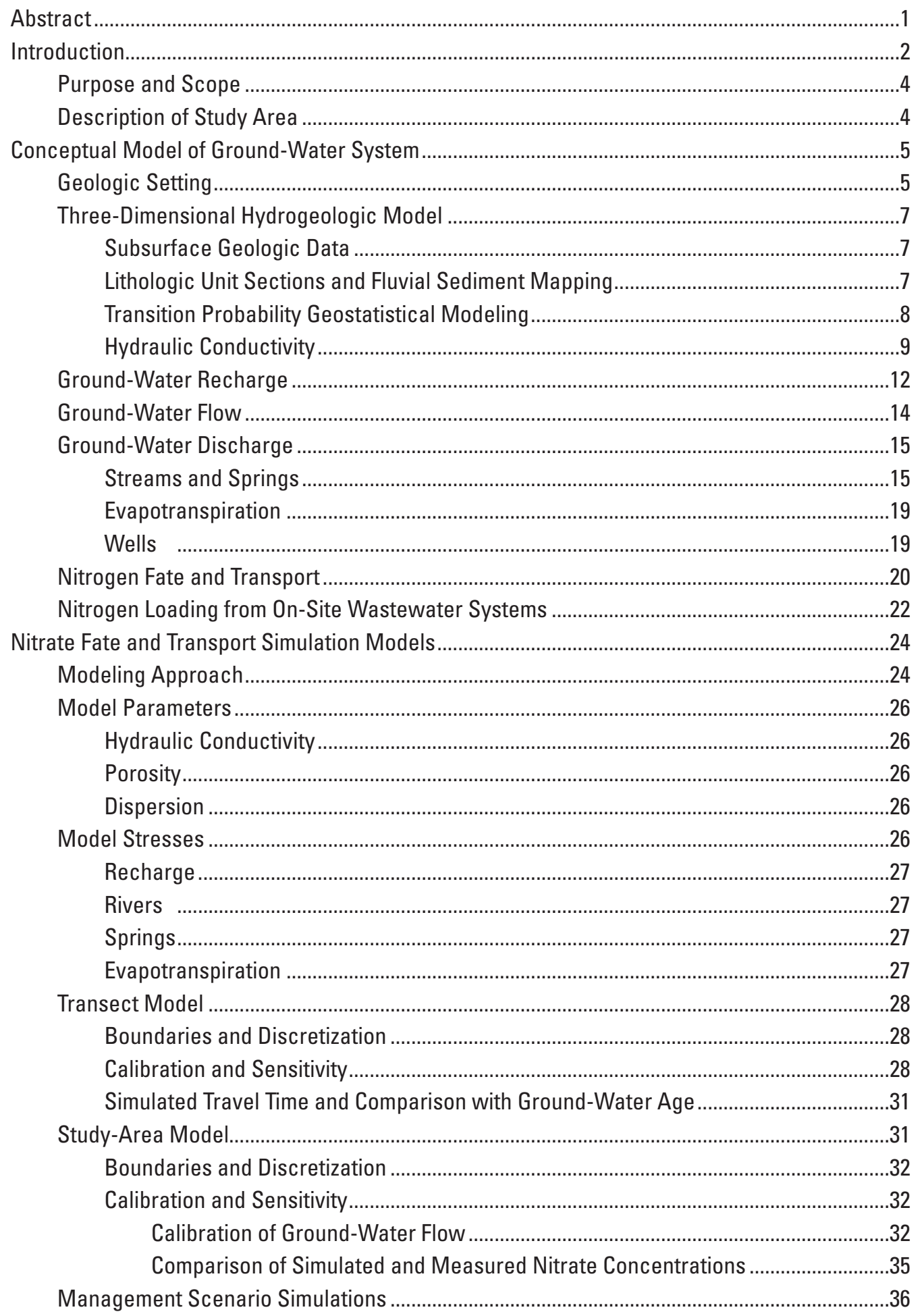




\section{Contents-Continued}

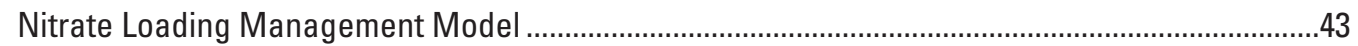

Formulation of Nitrate Loading Management Model ...........................................................43

Constraints on Ground-Water Nitrate Concentration....................................................43

Constraints on Discharge of Nitrate from Ground Water to Streams ..............................45

Constraints on Reduction of Nitrate Loading ............................................................... 45

Response-Matrix Technique for Solution of Nitrate Loading Management Model ................46

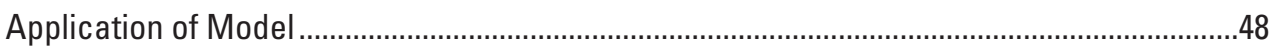

Sensitivity of Optimal Solution to Water-Quality Constraints ..........................................49

Ground-Water Nitrate Concentration...................................................................49

Ground-Water Nitrate Discharge Loading to Streams...........................................50

Sensitivity of Optimal Solution to Nitrate Loading Constraints ........................................50

Sensitivity of Optimal Solution to Cost Factors ............................................................51

Spatial Distribution of Loading for Optimal Solution ......................................................52

Comparison of Scenario Simulations and Optimal Solution ...............................................53

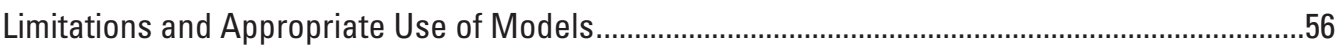

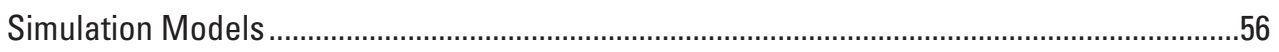

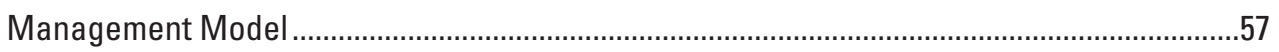

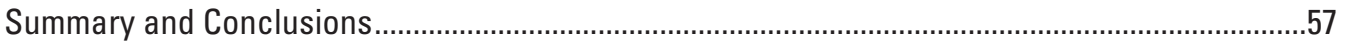

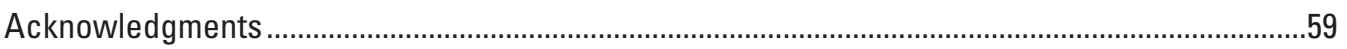

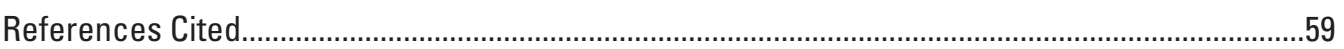

Appendix A. Vertical Hydraulic Head Gradient Data from Measurements Made on the Deschutes and Little Deschutes Rivers, in the La Pine, Oregon,

Study Area, October 23- November 4, 2000

\section{Plate}

Plate 1. Selected cross sections showing lithologic units of the La Pine region, Oregon 


\section{Figures}

Figure 1. Map showing location of La Pine study area, Oregon, and extent of the nitrate fate and transport model

Figure 2. Map showing generalized geology and hydrogeologic units of the La Pine

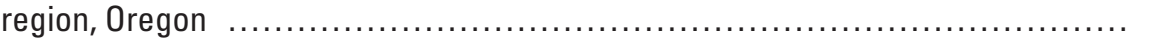

Figure 3. Cross sections showing three dimensional hydrogeologic model of the La Pine, Oregon, study area

Figure 4. Graphs showing distributions of estimated hydraulic conductivity values from slug tests and well-yield data

Figure 5. Map showing distribution of mean annual recharge, water-table elevation contours (June 2000), and locations of monitoring wells in the La Pine, Oregon, study area

Figure 6. Hydrographs showing water levels in selected wells in the La Pine, Oregon, study area

Figure 7. Map showing gaining and losing reaches of the Deschutes and Little Deschutes Rivers and locations of measurement sites for gain-loss surveys between October 1995 and October 2000 in the La Pine, Oregon, study area

Figure 8. Map showing estimated thickness of oxic ground-water layer in the shallow aquifer in the La Pine, Oregon, study area

Figure 9. Graph showing annual and cumulative estimated nitrate loading from on-site wastewater systems in the La Pine, Oregon study area, 1960-2005

Figure 10. Map showing spatial relations between the upper Deschutes Basin regional ground-water model, the La Pine study area model, and the transect model $\ldots . . .25$

Figure 11. Plan and section views of the transect model showing simulated water-levels, ground-water travel time, and particle paths in the La Pine, Oregon, study area

Figure 12. Map showing contours of simulated and observed heads (June 2000) for the La Pine, Oregon, study area

Figure 13. Graph showing simulated head residuals and observed heads (June 2000) from the La Pine, Oregon, study area

Figure 14. Boxplots showing measured and simulated nitrate concentrations in the La Pine, Oregon, study area, 1999

Figure 15. Map showing simulated nitrate concentrations near the water table in the La Pine, Oregon, study area, 1999

Figure 16. Graph showing historical nitrate loading from on-site wastewater systems and eight nitrate loading scenarios tested with the study-area model

Figure 17. Map showing simulated equilibrium ground-water nitrate concentrations near the water table for the base scenario in the La Pine, Oregon, study area

Figure 18. Map showing simulated equilibrium ground-water nitrate concentrations near the water table for 20 milligrams $\mathrm{N}$ per liter advanced treatment on-site wastewater systems in the La Pine, Oregon, study area

Figure 19. Map showing locations of management areas and ground-water nitrate concentration constraint locations in the Nitrate Loading Management Model for the La Pine, Oregon, study area 


\section{Figures-Continued}

Figure 20. Map showing locations of management areas near Burgess Road and management area 31 in the La Pine, Oregon, study area

Figure 21. Graph showing sensitivity of optimal loading solutions to ground-water nitrate concentration constraints in the La Pine, Oregon, study area

Figure 22. Graph showing sensitivity of optimal loading solutions to constraints on the minimum reduction in ground-water discharge loading to streams in the La

Pine, Oregon, study area

Figure 23. Graph showing sensitivity of optimal solution to minimum decentralized wastewater treatment performance standards for future homes in the La Pine, Oregon, study area

Figure 24. Diagram showing sensitivity of optimal solutions to relative cost difference of nitrate loading reduction for existing and future homes in the La Pine, Oregon, study area

Figure 25. Map showing optimal reduction in nitrate loading from existing homes in the La Pine, Oregon, study area

Figure 26. Map showing optimal reduction in nitrate loading from future homes in the La Pine, Oregon, study area

Figure 27. Graphs showing comparison of loading and water quality between optimal and nonoptimal management scenarios for the La Pine, Oregon, study area 56

\section{Tables}

Table 1. Markov chain model parameters and transition probabilities in the final hydrofacies model

Table 2. Hydraulic conductivity estimates from slug test data from wells near LaPine, Oregon

Table 3. Basin information for water-level monitoring wells in the La Pine, Oregon, study area

Table 4. Summary of data from stream gain-loss surveys on the Deschutes and Little Deschutes Rivers in the La Pine, Oregon, study area, 1995-2000

Table 5. Values of horizontal and vertical hydraulic conductivity for hydrofacies based on field data and model calibration in the La Pine, Oregon, study area....

Table 6. Summary of eight on-site wastewater management scenarios tested with the study-area model in the La Pine, Oregon, study area

Table 7. Summary of model simulation results for eight on-site wastewater management scenarios tested with the study-area model in the La Pine, Oregon, study area

Table 8. Response coefficients relating the effects of loading in nearby areas to the nitrate concentration at a constraint location in management area 31 in the La Pine, Oregon, study area 


\section{Conversion Factors, Datums, and Abbreviations and Acronyms}

Conversion Factors

\begin{tabular}{|c|c|c|}
\hline Multiply & By & To obtain \\
\hline acre & 0.4047 & hectare (ha) \\
\hline cubic foot per second per mile $\left(\mathrm{ft}^{3} / \mathrm{s} / \mathrm{mi}\right)$ & 0.04560 & $\begin{array}{l}\text { cubic meter per second per kilometer } \\
\left(\mathrm{m}^{3} / \mathrm{s} / \mathrm{km}\right)\end{array}$ \\
\hline cubic foot per second $\left(\mathrm{ft}^{3} / \mathrm{s}\right)$ & 0.02832 & cubic meter per second $\left(\mathrm{m}^{3} / \mathrm{s}\right)$ \\
\hline $\begin{array}{l}\text { cubic foot per second per square mile } \\
{\left[\left(\mathrm{ft}^{3} / \mathrm{s}\right) / \mathrm{mi}^{2}\right]}\end{array}$ & 0.01093 & $\begin{array}{l}\text { cubic meter per second per square kilometer } \\
\qquad\left[\left(\mathrm{m}^{3} / \mathrm{s}\right) / \mathrm{km}^{2}\right]\end{array}$ \\
\hline foot $(\mathrm{ft})$ & 0.3048 & meter $(\mathrm{m})$ \\
\hline foot per day (ft/d) & 0.3048 & meter per day $(\mathrm{m} / \mathrm{d})$ \\
\hline foot squared per day $\left(\mathrm{ft}^{2} / \mathrm{d}\right)^{*}$ & 0.09290 & meter squared per day $\left(\mathrm{m}^{2} / \mathrm{d}\right)$ \\
\hline gallon (gal) & 3.785 & liter (L) \\
\hline gallon per day (gal/d) & 0.003785 & cubic meter per day $\left(\mathrm{m}^{3} / \mathrm{d}\right)$ \\
\hline inch (in.) & 2.54 & centimeter $(\mathrm{cm})$ \\
\hline inch per year (in/yr) & 25.4 & millimeter per year $(\mathrm{mm} / \mathrm{yr})$ \\
\hline kilograms per day $(\mathrm{kg} / \mathrm{d})$ & 2.205 & pound per day (lb/d) \\
\hline kilogram per year $(\mathrm{kg} / \mathrm{yr})$ & 2.205 & pound per year (lb/yr) \\
\hline mile (mi) & 1.609 & kilometer $(\mathrm{km})$ \\
\hline million gallons per day (Mgal/d) & 0.04381 & cubic meter per second $\left(\mathrm{m}^{3} / \mathrm{s}\right)$ \\
\hline pound, avoirdupois (lb) & 0.4536 & kilogram $(\mathrm{kg})$ \\
\hline pound per year (lb/yr) & 0.4536 & kilogram year (kg/yr) \\
\hline square mile $\left(\mathrm{mi}^{2}\right)$ & 2.590 & square kilometer $\left(\mathrm{km}^{2}\right)$ \\
\hline
\end{tabular}

*Transmissivity: The standard unit for transmissivity is cubic foot per day per square foot times foot of aquifer thickness $\left[\left(\mathrm{ft}^{3} / \mathrm{d}\right) / \mathrm{ft}^{2}\right] \mathrm{ft}$. In this report, the mathematically reduced form, foot squared per day $\left(\mathrm{ft}^{2} / \mathrm{d}\right)$, is used for convenience.

Concentrations of chemical constituents in water are given either in milligrams per liter (mg/L) or micrograms per liter $(\mu \mathrm{g} / \mathrm{L})$.

Datums

Vertical coordinate information is referenced to the North American Vertical Datum of 1929 (NAVD 29).

Horizontal coordinate information is referenced to the North American Datum of 1983 (NAD 83).

Elevation, as used in this report, refers to distance above the vertical datum. 


\section{Conversion Factors, Datums, and Abbreviations and Acronyms-Continued}

Abbreviations and Acronyms

\begin{tabular}{ll}
\hline Abbreviations and Acronyms & Meaning \\
\hline $\mathrm{kg} \mathrm{N} / \mathrm{yr}$ & kilograms of nitrogen per year \\
$\mathrm{lb} \mathrm{N} / \mathrm{yr}$ & pounds of nitrogen per year \\
$\mathrm{mg} \mathrm{N} / \mathrm{L}$ & milligrams of nitrogen per liter \\
$\mathrm{my}$ & million years \\
$\mathrm{NDP}$ & La Pine National On-Site Wastewater Demonstration Project \\
$\mathrm{NLMM}$ & Nitrate Loading Management Model \\
ODEQ & Oregon Department of Environmental Quality \\
PLSS & Public Land Survey System \\
RMSE & root mean square error \\
TDC & Transferable Development Credit \\
USEPA & U.S. Environmental Protection Agency \\
USGS & U.S. Geological Survey \\
\hline
\end{tabular}




\title{
Evaluation of Approaches for Managing Nitrate Loading from On-Site Wastewater Systems near La Pine, Oregon
}

\author{
By David S. Morgan'1, Stephen R. Hinkle' ${ }^{1}$, and Rodney J. Weick ${ }^{2}$
}

\section{Abstract}

This report presents the results of a study by the U.S. Geological Survey, done in cooperation with the Oregon Department of Environmental Quality and Deschutes County, to develop a better understanding of the effects of nitrogen from on-site wastewater disposal systems on the quality of ground water near La Pine in southern Deschutes County and northern Klamath County, Oregon. Simulation models were used to test the conceptual understanding of the system and were coupled with optimization methods to develop the Nitrate Loading Management Model, a decision-support tool that can be used to efficiently evaluate alternative approaches for managing nitrate loading from on-site wastewater systems. The conceptual model of the system is based on geologic, hydrologic, and geochemical data collected for this study, as well as previous hydrogeologic and water quality studies and field testing of on-site wastewater systems in the area by other agencies.

On-site wastewater systems are the only significant source of anthropogenic nitrogen to shallow ground water in the study area. Between 1960 and 2005 estimated nitrate loading from on-site wastewater systems increased from 3,900 to 91,000 pounds of nitrogen per year. When all remaining lots are developed (in 2019 at current building rates), nitrate loading is projected to reach nearly 150,000 pounds of nitrogen per year. Low recharge rates ( $2-3$ inches per year) and ground-water flow velocities generally have limited the extent of nitrate occurrence to discrete plumes within 20-30 feet of the water table; however, hydraulic-gradient and age data indicate that, given sufficient time and additional loading, nitrate will migrate to depths where many domestic wells currently obtain water. In 2000, nitrate concentrations greater than 4 milligrams nitrogen per liter ( $\mathrm{mg} \mathrm{N} / \mathrm{L}$ ) were detected in 10 percent of domestic wells sampled by Oregon Department of Environmental Quality.

\footnotetext{
${ }^{1}$ U.S. Geological Survey

${ }^{2}$ Oregon Department of Environmental Quality
}

Numerical simulation models were constructed at transect (2.4 square miles) and study-area (247 square miles) scales to test the conceptual model and evaluate processes controlling nitrate concentrations in ground water and potential ground-water discharge of nitrate to streams. Simulation of water-quality conditions for a projected future build-out (base) scenario in which all existing lots are developed using conventional on-site wastewater systems indicates that, at equilibrium, average nitrate concentrations near the water table will exceed $10 \mathrm{mg} \mathrm{N} / \mathrm{L}$ over areas totaling 9,400 acres. Other scenarios were simulated where future nitrate loading was reduced using advanced treatment on-site systems and a development transfer program. Seven other scenarios were simulated with total nitrate loading reductions ranging from 15 to 94 percent; simulated reductions in the area where average nitrate concentrations near the water table exceed $10 \mathrm{mg} \mathrm{N} / \mathrm{L}$ range from 22 to 99 percent at equilibrium. Simulations also show that the ground-water system responds slowly to changes in nitrate loading due to low recharge rates and ground-water flow velocity. Consequently, reductions in nitrate loading will not immediately reduce average nitrate concentrations and the average concentration in the aquifer will continue to increase for 25-50 years depending on the level and timing of loading reduction. The capacity of the ground-water system to receive on-site wastewater system effluent, which is related to the density of homes, presence of upgradient residential development, ground-water recharge rate, ground-water flow velocity, and thickness of the oxic part of the aquifer, varies within the study area.

Optimization capability was added to the study-area simulation model and the combined simulation-optimization model was used to evaluate alternative approaches to management of nitrate loading from on-site wastewater systems to the shallow alluvial aquifer. The Nitrate Loading Management Model (NLMM) was formulated to find the minimum reductions from projected future loading required to maintain or restore ground-water nitrate concentrations or ground-water discharge of nitrate to streams below userspecified levels. Sensitivity analysis of the NLMM showed that loading primarily is constrained by nitrate concentration in the shallow part of the oxic ground-water system, within 5-10 feet of the water table. 


\section{Introduction}

Rural residential areas near La Pine in southern Deschutes County and northern Klamath County, Oregon (fig. 1) have experienced rapid growth in recent years. More than 9,000 residential lots, ranging in size from 0.5 to 10 acres, are in the area where existing and future homes will rely on individual on-site wastewater systems and wells for wastewater disposal and water supply. Most existing wells have screened intervals within $50 \mathrm{ft}$ of land surface and extract water from alluvial sands and gravels that constitute the primary aquifer in the area. The water table is shallow, typically is less than $20 \mathrm{ft}$ below land surface, and in some low-lying areas rises seasonally to within $2 \mathrm{ft}$ of land surface. Sandy soils derived from pumice contain little organic matter and allow rapid infiltration of on-site wastewater effluent.

The vulnerability of the shallow aquifer has led to concern by County and State land-use and environmentalhealth regulators that ground-water quality may be impaired if development continues at planned densities using conventional on-site wastewater systems. (In this report, conventional on-site systems include standard, pressure-distribution, and packed-bed [sand] filter systems). Another potential concern is the quality of local streams. The Deschutes and Little Deschutes Rivers, which flow through developed areas near La Pine, have been listed as "water-quality impaired" for temperature and turbidity; nutrient loading from ground water has been identified as a potential contributor to excessive algal growth in some reaches (Anderson, 2000; Jones, 2003) that may exacerbate water-quality concerns.

On-site wastewater systems are the principal source of nitrogen to the shallow ground-water system in the La Pine area (Century West Engineering, 1982; Oregon Department of Environmental Quality, 1994; Hinkle and others, 2007a). On-site wastewater systems do not remove nitrogen from wastewater; however, most nitrogen is converted from organic nitrogen and ammonium to nitrate before it reaches the saturated part of the ground-water system (water table). Once in the saturated zone, nitrate generally is stable in the presence of oxic ground water (ground water that contains dissolved oxygen). Adsorption or chemical reactions within the flow system do not readily remove nitrate. Nitrate is a human health concern because it can cause methemoglobinemia (BlueBaby Syndrome) in infants (http://www.atsdr.cdc.gov/HEC/ CSEM/nitrate/). Nitrogen also is an environmental concern as a potential source of nutrient enrichment to streams. Nutrient enrichment contributes to algal blooms detected in the Deschutes and Little Deschutes Rivers. The U.S. Environmental Protection Agency (USEPA) has established
$10 \mathrm{mg} \mathrm{N} / \mathrm{L}$ as the maximum allowable nitrate concentration in drinking water for public water supply systems. Oregon, by statute, has established a nitrate concentration of $7 \mathrm{mg} \mathrm{N} / \mathrm{L}$ as the value at which action may be taken to control water-quality degradation by regulatory means.

The present location of the city of La Pine (fig. 1) was the first concentrated development within the study area. The first building permits recorded in what was then called the "core area" date from 1910. In 2006, the core area was incorporated as the city of La Pine. Degradation of ground-water quality by on-site wastewater systems was first documented in the core area in 1979 by Oregon Department of Environmental Quality (ODEQ) after samples from 46 wells revealed that water from 8 wells contained nitrate concentrations greater than $10 \mathrm{mg} \mathrm{N} / \mathrm{L}$ (Cole, 2006) and a maximum of $26 \mathrm{mg} \mathrm{N} / \mathrm{L}$. Nitrate concentrations in ground water as much as $41 \mathrm{mg} \mathrm{N} / \mathrm{L}$ were detected in a follow-up study in 1982 (Century West Engineering, 1982). These results led to an ODEQ administrative rule requiring community sewage collection, treatment, and disposal for the core area. In 1993, ODEQ sampled 36 wells in residential areas near La Pine as part of its statewide Ambient Groundwater Monitoring Program and detected nitrate concentrations greater than $2 \mathrm{mg} \mathrm{N} / \mathrm{L}$ in 19 wells. They concluded that elevated concentrations were caused by anthropogenic influences (on-site wastewater systems) (Cole, 2006). Concentrations were greater than $10 \mathrm{mg}$ N/L in 4 (11 percent) of the 36 wells sampled. In 1994, Deschutes County requested that ODEQ further evaluate ground-water quality in the area. Water from more than 120 domestic and public water-supply wells was sampled in 1994 and 1995 and ODEQ delineated several areas of elevated nitrate concentrations underlying the most densely developed parts of the region (R.J. Weick, ODEQ, written commun., 1998; Cole, 2006). As part of the 1995 assessment, ODEQ constructed simplified nitrate transport models which included basic assumptions on nitrogen chemistry. The ODEQ transport models predicted that nitrate concentrations would exceed drinking water standards within 20 years of full build-out (R.J. Weick, ODEQ, written commun., 1998; Cole, 2006).

In 1999, a nitrate concentration threshold of $5 \mathrm{mg} \mathrm{N} / \mathrm{L}$ was selected for the La Pine area by the Deschutes County Working Group on Groundwater Issues for the South Deschutes Basin to serve as a "proactive target to protect the Basin's groundwater quality." The working group also recommended that ODEQ “....address these problems and concerns by considering the adoption of a geographic rule... to protect the Basin's groundwater resource." (http://www. co.deschutes.or.us/download.cfm?DownloadFile=507DDA68BDBD-57C1-902813CCF281DDF0). 


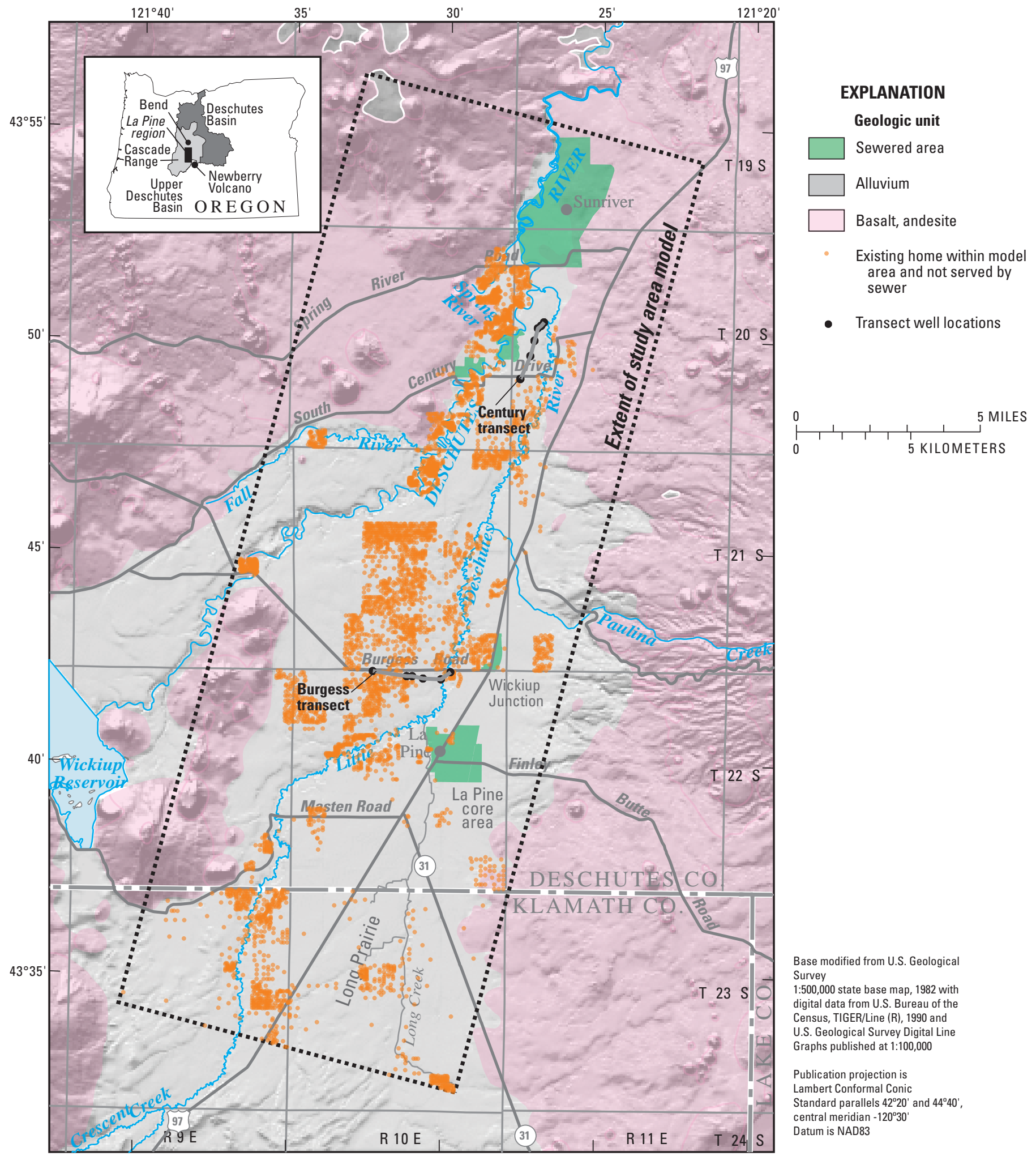

Figure 1. Location of La Pine study area, Oregon, and extent of the nitrate fate and transport model. 
In 1999, Deschutes County and ODEQ identified the need for an improved understanding of the processes that affect the transport and fate of nitrogen in the La Pine area before making decisions among alternatives for managing ground-water quality. To help achieve that understanding, Deschutes County and ODEQ applied for and received funding from the USEPA to evaluate methods to protect ground-water quality in the area (Oregon Department of Environmental Quality, 2004a) as part of the La Pine National On-Site Wastewater Demonstration Project (NDP). The objectives of the NDP also included (1) assessing the effectiveness of advanced treatment (denitrifying) systems for on-site wastewater and (2) developing a more complete and useful understanding of processes that affect nitrogen in the ground-water system. The second objective was the subject of a cooperative study by the ODEQ, Deschutes County Community Development Department (CDD) and the Oregon Water Science Center of the U.S. Geological Survey (USGS).

The primary objective of this study was to develop a thorough understanding of the hydrologic and chemical processes that affect the movement and fate of nitrogen within the shallow aquifers of the La Pine region. A secondary objective was to provide a method for analyzing the effects of existing and future development on water quality. This understanding will provide local and State resource management agencies with information and tools needed to determine the probable effects of present and future land use on nitrogen concentrations in the shallow aquifer and on nitrogen loading from ground water to the Deschutes and Little Deschutes Rivers.

\section{Purpose and Scope}

This report describes conceptual, simulation, and management models of the ground-water system near the community of La Pine in central Oregon. The description of the conceptual model provides a background for the development of the simulation and management models and includes the geologic framework, hydrologic processes, and processes affecting nitrate transport and fate. The description of the simulation model includes a discussion of how the processes and boundaries of the system were represented in a computer simulation model, how the model was calibrated, and the results of predictive simulations. The simulation model was enhanced as a decision-support tool (management model) by incorporating optimization techniques that allow users to identify management solutions that will meet water quality goals. The discussion of the management model includes a description of the method of incorporating optimization techniques with the simulation model, the formulation of the management problem, and analysis of the sensitivity of optimal management solutions to the values of various constraints.

\section{Description of Study Area}

The La Pine study area encompasses about $250 \mathrm{mi}^{2}$ within the Deschutes River drainage basin in central Oregon (fig. 1). The area is drained by the Deschutes River and tributaries including the Little Deschutes, Spring, and Fall Rivers. Land-surface elevation ranges from about 4,000 ft near the Deschutes River at the northern boundary of the study area, to nearly $5,700 \mathrm{ft}$ at the peaks of volcanic buttes in the northwestern corner of the study area. Most of the study area lies in the relatively low-relief alluvial plain of the Deschutes and Little Deschutes Rivers at elevations between 4,150 and $4,300 \mathrm{ft}$. The populated areas in the study area include low and medium density rural-residential subdivisions adjacent to and between the Deschutes and Little Deschutes Rivers extending northward from La Pine to the community of Sunriver (fig. 1). The subdivisions are surrounded by Federal lands managed by the U.S. Forest Service and Bureau of Land Management.

The study area boundaries were selected to include the most densely populated parts of southern Deschutes County and northern Klamath County, where on-site wastewater systems are the predominant method of wastewater disposal for existing and future residential development. The boundaries also were selected to include the principal area of the shallow alluvial aquifer that provides drinking water for most of the population in the La Pine area. The data collection and analysis for this study was focused in the $247 \mathrm{mi}^{2}$ area of the study-area flow and transport simulation model (fig. 1).

Residential development in the area began to accelerate in the 1960s (Century West Engineering, 1982) and almost 3,000 new residential lots were created in the 1970s in response to demand for vacation homes and full-time residences. Although lots range in size from 0.5 to more than 10 acres, 58 percent of lots in the study area in 2000 were less than 1 acre and 82 percent were less than 2 acres. The population of the area was less than 1,000 in 1960, and increased to about 5,600 in 1981 (Century West Engineering, 1982), and was approximately 14,000 in 2000 (U.S. Bureau of the Census, 2000).

Land use is primarily low- to medium-density residential. Commercial and medium density residential areas are in the incorporated City of La Pine (including the La Pine "core area" and Wickiup Junction area) and industrial development is immediately east of the core area. Agricultural lands cover less than 4 percent of the study area and most of that area is nonirrigated pasture (Tim Berg, Deschutes County Community Development Department, written commun., 2004).

The climate of the area primarily is controlled by eastward moving air masses from the Pacific Ocean. Orographic precipitation in the Cascade Range results in more than $200 \mathrm{in} / \mathrm{yr}$ in some locations, although precipitation rates in the lower part of the Deschutes River basin average as little as $10 \mathrm{in} / \mathrm{yr}$. Mean annual (1971-2000) precipitation in the La Pine area ranges from 16 to 24 in. (Daly and Gibson, 2002). 


\section{Conceptual Model of Ground-Water System}

\section{Geologic Setting}

The La Pine study area of the upper Deschutes River basin is a sediment-filled graben feature that lies within the geologically complex transition area between three geologic provinces: the Cascade Range, the Basin and Range Province, and the High Lava Plains. The La Pine study area shares attributes characteristic of each of these geologic provinces. The Cascade Range forms the western margin of the La Pine study area. Newberry volcano forms the eastern study area margin and transition between the extensional Basin and Range Province and the High Lava Plains. North to northnorthwest trending and northeast trending en echelon faults define the eastern boundary of the graben forming the La Pine study area.

The Cascade Range is a constructional feature of northsouth trending eruptive centers that extends from northern California to southern British Columbia and has been volcanically active for the past 35 million years (Sherrod and Pickthorn, 1989). In central Oregon, these volcanic eruptive centers are stratovolcanoes, such as the North, Middle, and South Sister, and Mount Jefferson, all with elevations greater than 10,000 ft (Lite and Gannett, 2002).

The Basin and Range Province is a region of crustal extension that covers most of the western United States and is characterized by north to northwest trending sub parallel fault-bounded down-dropped grabens forming fault-block ranges with basins typically 10-20 mi wide. In central Oregon, the La Pine graben is defined by north-northwest trending and northeast trending down-dropped faults (Allen, 1966; MacLeod and Sherrod, 1992) forming the sedimentfilled 10-15-mi wide subbasin with characteristics similar to those of Basin and Range extensional features along the northwestern transitional boundary in northeastern California and northwestern Nevada.

The north-south trending graben that underlies the La Pine study area is estimated to have down-dropped 1,800 to 2,400 ft based on gravity and aeromagnetic anomalies (Couch and Foote, 1985; MacLeod and Sherrod, 1992) Formation of the basin began during the mid-Pleistocene between 0.6 and 1 my (million years) ago (Couch and Foote, 1985; Gettings and Griscom, 1988; Sherrod and Pickthorn, 1989; MacLeod and Sherrod, 1992; MacLeod and others, 1995) and subsequently has been filled with several hundred feet of sediment. Nearly 1,400 ft of sediment have been penetrated by deep water-supply wells drilled in the study area. Descriptions of sediment lithology in drillers' reports for water wells indicate that graben formation was concurrent with volcanism and late Pleistocene glacial outwash deposition. Periods of active volcanism and quiescence and fluvial and lacustrine deposition during graben development created a complex sequence of intercalated lava flows, ignimbrites, and alluvial deposits. The depositional history is further complicated by fluvial-lacustrine deposition during the Pleistocene.

Many basin-fill sediments in the La Pine study area are fine-grained lacustrine silt and clay. Within these fine-grained deposits are fine to coarse fluvial sand and gravel channelfill deposits and discontinuous cinder, pumice- and ash-fall beds. Methane, ammonium, and reduced iron detected in water well samples (Hinkle and others, 2007a) from these fine-grained deposits indicate a predominant quiescent marsh and lake depositional environment with episodic volcanic deposition. This low-energy depositional environment may be related to the onset and development of Newberry volcano about 0.7 my ago. MacLeod and others (1995) indicated that Newberry lavas backed up against Cascade Range lava flows, blocking the channel of the Deschutes River which created a lake and marsh environment over much of the study area. A pumice bed exposed near the top of the lacustrine deposits and about $35 \mathrm{ft}(10.8 \mathrm{~m})$ below the fluvial/lacustrine contact at Pringle Falls on the Deschutes River is 0.22 to 0.17 my old (Herrero-Bervera and others, 1994).

About 0.2 my ago the depositional environment probably underwent an abrupt change from lacustrine to predominantly fluvial with deposition of heterogeneous silt, fine to coarse sand, gravel, and pumaceous sand and gravel. These deposits are likely associated with Pleistocene glaciation of the Cascade Range and Newberry Volcano. These highenergy deposits are capped by a study area wide 3-5 ft-thick pumice- and ash-fall deposit from the Mt. Mazama eruption of 7,627 \pm 150 years ago (Zdanowicz and others, 1999). The Deschutes, Little Deschutes, and Fall Rivers have reworked and down-cut through the Mt. Mazama pumice and ash-fall deposit. The high degree of heterogeneity noted in lithologic descriptions in drillers' reports indicate an active fluvial depositional environment in the central and southern parts of the La Pine study area and deposition more characteristic of a lacustrine environment in the northern part of the study area. Based on interpretation of more than 460 water-well logs, fluvial silt, sand, and gravel deposits were determined to range in thickness from less than $10 \mathrm{ft}$ in the northern study area, to as much as $100 \mathrm{ft}$ in the central and southern parts of the study area (fig. 2). A thin veneer of gravel overlying a paleosol was observed in several monitoring wells in the study area. The presence of the paleosol may represent post-Pleistocene glacial soil development. The thin sand and gravel veneer overlying the paleosol may represent the brief early Holocene glacial event that predates the mid-Holocene Mt. Mazama eruption. 


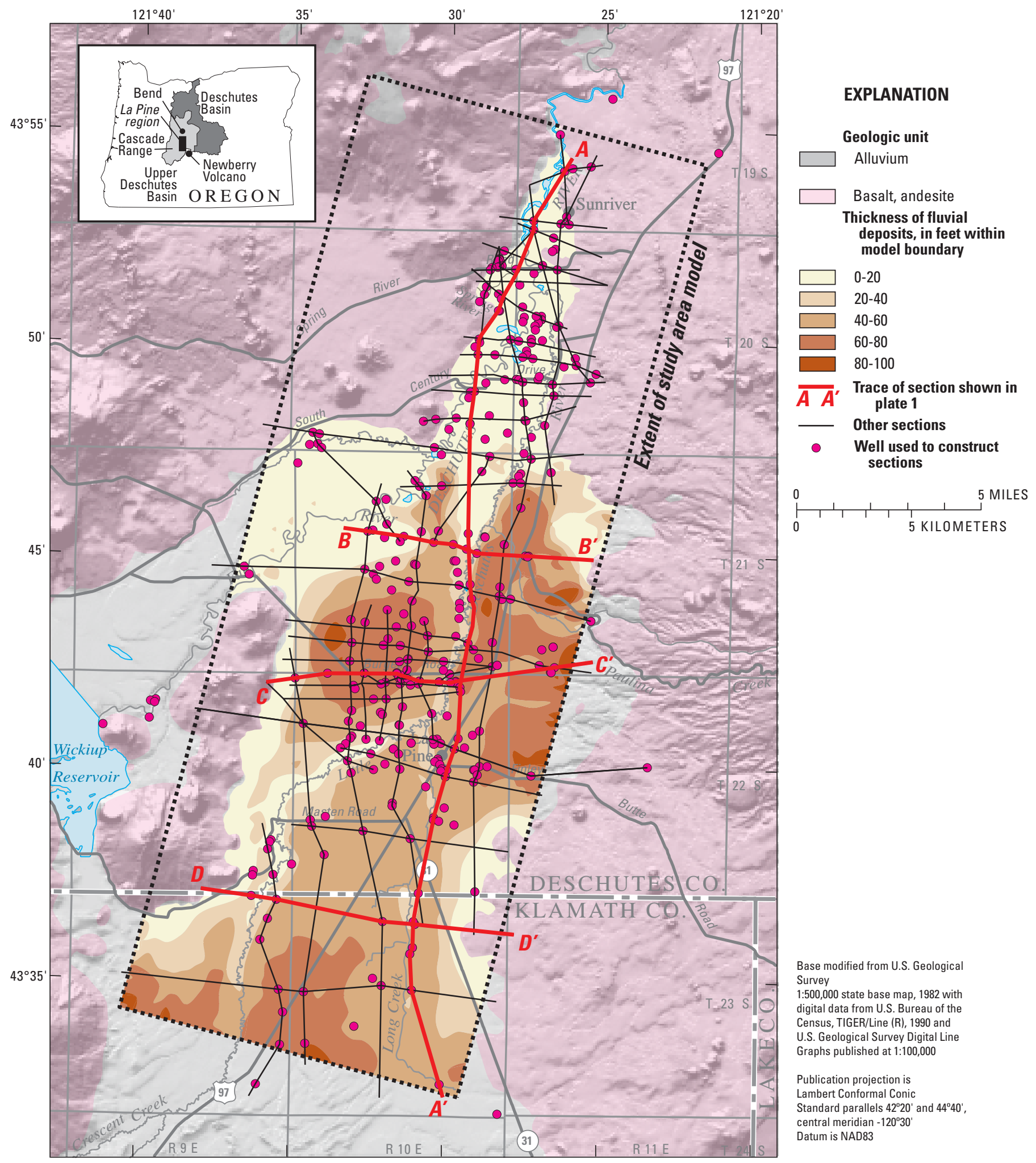

Figure 2. Generalized geology and hydrogeologic units of the La Pine region, Oregon. 


\section{Three-Dimensional Hydrogeologic Model}

A detailed characterization of subsurface heterogeneity can substantially improve the reliability of models of ground-water contaminant transport (Fogg, 1986; Anderson 1987; Johnson and Dreiss, 1989). In this study, standard hydrogeologic interpretation and analysis techniques, including construction of two-dimensional geologic sections and surface maps, were used in conjunction with transition probability geostatistics to develop a three-dimensional hydrogeologic model that represents the heterogeneity of the complex glaciofluvial system.

\section{Subsurface Geologic Data}

The primary source of subsurface geologic data was the nearly 5,400 drillers' reports available (as of 1999) for domestic and public water supply wells in the study area. Although these reports are plentiful, the quality of lithologic descriptions in the reports is inconsistent. The spatial distribution of domestic wells also is not ideal for developing a detailed, three-dimensional geologic model of the groundwater system; as would be expected, domestic wells are concentrated in areas of residential development and tend to be completed at the shallowest depth that a satisfactory yield can be obtained. A subset of 346 wells was visited as part of this and previous studies (Gannett and others, 2001) to determine accurate locations and collect water-level and other data. The subset of wells visited was selected to provide the best spatial distribution within the study area and good descriptions of geologic materials penetrated by the well. Drillers' reports for an additional 118 wells were selected to provide information in areas where field-located wells were not available. Although these wells were not visited, the drillers' reports included superior descriptions of geologic materials and well locations could be accurately estimated using tax lot information.

Descriptions of geologic materials were transcribed to a database from the drillers' reports using a standardized set of lithologic descriptors developed for this study. A twoletter descriptor was assigned to the primary lithology, and, if needed, secondary lithology reported by the driller for each depth interval. For example, if the driller reported a layer of "gravel with sand" between 40 and $80 \mathrm{ft}$, the interval was assigned a primary descriptor of GR for gravel and a secondary descriptor of SA for sand. This system retained most of the detail of the original description by the driller and allowed for comparison and analysis of lithology between wells. Thirty-six descriptors were used to describe primary and secondary lithology. Combinations of the primary and secondary descriptors resulted in 157 unique lithologic descriptors for the 464 wells used in the analysis.

\section{Lithologic Unit Sections and Fluvial Sediment Mapping}

The 157 unique lithologic descriptors were grouped into six lithologic units. Five lithologic units comprised unconsolidated sediments: clay-silt, pumice-sand, sand, sand-gravel, and gravel. The sixth lithologic unit represented consolidated and semi-consolidated volcanic rocks such as basalt, basaltic andesite, and tuff. The lithologic unit data for each well were stored in a Geographic Information System (GIS) database that facilitated data interpretation and construction of 34 two-dimensional cross sections through the study area showing the thickness and extent of the primary lithologic units. Locations of the sections are shown in figure 2 and selected sections are shown on plate 1 .

Although deep wells are somewhat sparse in the study area, the sections show that as much as $100 \mathrm{ft}$ of fluvial silt, sand, and gravel overlie predominately fine-grained lacustrine sediments throughout the study area (plate 1). A relatively sharp transition exists between the overlying fluvial sediments and the basal lacustrine silt and clay, basalt, and volcaniclastic deposits. The elevation of the top of the lacustrine sediments was mapped using data from the 464 wells (fig. 2). Infrequent sand and gravel lenses as well as pumice and ash beds are present within the basal lacustrine sediments, but because of their discontinuous nature, they are not regionally significant sources of water to wells. The thickness of the fluvial sediments that constitute the primary aquifers in the study area was computed by subtracting the elevation of the top of the basal lacustrine sediments from land surface elevation (fig. 2). The greatest thicknesses of fluvial sediments are in the central, east-central, and south-central parts of the study area where higher elevations occur within the study area. Deposition of Pleistocene alluvial sediments from fans emanating from Newberry volcano contributes to the thickness of coarse sediments on the eastern margin of the study area. The total thickness (unsaturated and saturated) of fluvial sediments exceeds $60 \mathrm{ft}$ over much of this area. The fluvial sediments are thinner in three areas: (1) within the floodplain of the Little Deschutes River where they have been eroded, (2) at the margins of the study area where they overlie shallow tuffs and basaltic and andesitic volcanic rocks, and (3) in the northern part of the study area where lacustrine sediments are closer to the surface (fig. 2).

Interpretation of the geologic data during construction of the two-dimensional sections revealed that there is a greater degree of heterogeneity within the fluvial part of the system than could be delineated using traditional methods of interpretation using drillers' reports as the primary data source. The drillers' reports were useful for defining the vertical heterogeneity at each well location; however, because 
of the distance between wells and the uncertainty in the lithologic descriptions, it was not possible to accurately represent the lateral heterogeneity of the fluvial hydrofacies. Another consideration was the difficulty in constructing a fully three-dimensional hydrogeologic model from the twodimensional representations in the lithofacies sections.

Important information on the nature and proportion of lithologic units and dimensions and interconnectedness of depositional features was gained through the process of constructing the lithologic unit sections. This information and the location of the lower boundary of the fluvial aquifer system were used as supplemental information in the development of the three-dimensional hydrogeologic model described in the next section.

\section{Transition Probability Geostatistical Modeling}

A transition probability geostatistical approach was used to model the heterogeneity of the fluvial sediments that constitute the shallow aquifer near La Pine. The method was applied using the suite of programs, Transition Probability Geostatistical Software (T-PROGS), documented by Carle (1999). T-PROGS implements a transition probability/Markov approach to geostatistical analysis and simulation of spatial distributions of categorical variables (such as hydrofacies). The approach uses the probabilities of lateral and vertical transitions between hydrofacies to define spatial variability. The transition probabilities, volumetric proportion of facies, and mean lengths of depositional features are the parameters used to fit a three-dimensional Markov chain model to geologic data from drillers' logs and subjective knowledge based on an understanding of the depositional environment. Once a satisfactory Markov chain model is obtained, it is used in sequential indicator simulation with simulated annealing to produce realizations of the subsurface facies distributions that are conditioned using the observed geologic data. One advantage of the transition probability method is the ability to easily incorporate subjective or "soft" geologic information into the Markov chain model. Details on the theoretical development of the transition probability method, as wells as examples and comparisons with other methods, are given in Carle and Fogg (1996, 1997), Carle and others (1998), and Weissmann and others (1999).

The transition probability method was used to model the distribution of facies within the fluvial sediments only. The lacustrine sediments were not included because the transition probability method is predicated on the assumption that all the sediments within the modeled area were emplaced under similar depositional conditions.
A hydrofacies is defined as one or more lithologic units that have similar hydraulic characteristics. Three hydrofacies were used in the hydrogeologic model: (1) clay-silt, (2) sand, and (3) gravel. The five lithologic units used to subdivide the fluvial sediments in the sections on plate 1 were reduced to three hydrofacies by combining units with similar hydraulic characteristics. The clay-silt hydrofacies represent flood plain deposits with low hydraulic conductivity. The sand hydrofacies include varying amounts of silt and represent levee and proximal overbank deposits with moderate hydraulic conductivity. The gravel hydrofacies includes varying amounts of sand and represents channel deposits with high hydraulic conductivity.

In the rare case where there are abundant, high quality core data, geophysical logs, and detailed lithologic descriptions, the parameters for the Markov model can be estimated directly from bivariate statistics (variograms) for the hydrofacies. More commonly, as in the La Pine study area, most available geologic data are obtained from drillers' reports. Another limitation of the well data stems from the lack of correspondence between the scale of depositional features (for example, channel deposits) that have mean lengths of 10 s or 100 s of feet, and the spacing of data points (wells) that may be 100 s or 1,000 s of feet. The disparity in the scales of the system and the data available to characterize it makes quantifying lateral transition probabilities based solely on well data difficult. However, the transition probability approach provided a means of including the geologic knowledge gained through the process of developing the two-dimensional lithologic unit sections.

The mean lengths of the high-hydraulic conductivity gravel hydrofacies and the low hydraulic conductivity claysilt hydrofacies were estimated by manually measuring the length of lithologic units interpreted in the 34 lithologic unit sections (examples shown on plate 1) and computing average lengths for each hydrofacies in the lateral (strike and dip) and vertical dimensions. The depositional strike was aligned with the northeast-southwest strike of the study area (fig. 2). The estimates of lateral mean lengths for the gravel hydrofacies based on the lithologic unit sections were larger than expected for channel deposits typically found in fluvial systems analogous to the Little Deschutes and Deschutes River systems in the La Pine study area. The lateral mean lengths for the gravel hydrofacies were reduced based on measurements of present channel geometry, and meander and oxbow features identified from aerial photography. The estimated mean lengths for the gravel hydrofacies were modified through a trial and error process until the Markov chain model produced a hydrofacies realization that was consistent with geomorphologic observations. 
The volumetric proportions of the hydrofacies were 10 , 50, and 40-percent for gravel, sand, and clay-silt, respectively. The sand hydrofacies was selected as the "background" category because it represented the highest proportion of materials in the system. The transition probabilities (table 1) need only be specified for the nonbackground hydrofacies. The probabilities are expressed as decimal percentages; for example, there is a 30-percent probability of transitioning from the gravel facies to the clay-silt facies in the strike or dip direction, but only a 15-percent probability of transitioning from clay-silt to gravel.

The grid used to create the fluvial hydrofacies model had cell dimensions of $500 \mathrm{ft}$ horizontally along the depositional strike and dip and $5 \mathrm{ft}$ vertically. These cell dimensions were sufficiently small to allow good representation of the gravel and clay-silt facies (within the sand matrix) with mean horizontal and vertical lengths of 1,500-8,100 ft and 8-10 ft, respectively (table 1). The overall dimensions of the modeled region are 138,000 by $50,000 \mathrm{ft}$ along the depositional strike and dip, and $120 \mathrm{ft}$ along the vertical dimension. The T-PROGS program was used with the Markov chain parameters to generate the three-dimensional distribution of the fluvial hydrofacies. The elevation of the base of the fluvial sediments was contoured using drillers' log data; and cells within the hydrogeologic model below the base of the fluvial sediments were assigned to the lacustrine hydrofacies. The surficial geologic map (fig. 2) was used to assign cells to the basalt hydrofacies and land surface elevation from a DEM was used to "remove" cells from the hydrogeologic model that were above land surface. Sections through the complete threedimensional hydrogeologic model are shown in figure 3.

Once the appropriate parameters for the Markov Chain model are determined, many equally probable realizations of the hydrostratigraphy of the fluvial hydrofacies can be simulated using the T-PROGS program. Each realization would be consistent with the data from drillers' logs and interpretations made during construction of the twodimensional sections used to estimate the mean lengths.

Table 1. Markov chain model parameters and transition probabilities in the final hydrofacies model.

\begin{tabular}{lccc}
\hline \multirow{2}{*}{ Hydrofacies } & \multicolumn{3}{c}{ Mean length (feet) } \\
\cline { 2 - 4 } & Strike & Dip & Vertical \\
\hline Gravel & 3,000 & 1,500 & 10 \\
Clay-silt & 8,100 & 5,600 & 8 \\
\hline \multicolumn{1}{c}{ Hydrofacies } & \multicolumn{3}{c}{ Transition probability } \\
(From $\longrightarrow$ To) & \multicolumn{3}{c}{ (decimal percentage) } \\
\hline Gravel $\longrightarrow$ Clay-silt & 0.3 & 0.3 & 0.4 \\
Clay-silt $\longrightarrow$ Gravel & .15 & .15 & .25 \\
\hline
\end{tabular}

The capability to generate many realizations of the hydrostratigraphy represents a potentially powerful tool for evaluating the effects of hydrogeologic uncertainty on simulation models. Using multiple realizations, uncertainty in simulated nitrate concentrations resulting from uncertainty in the hydrogeologic model could be evaluated. While time consuming, this capability could provide important information on the sensitivity of model results to hydrogeologic uncertainty.

This capability would be especially useful for contaminant transport models in highly heterogeneous systems with large contrasts in hydraulic conductivity between hydrofacies where the objective was to simulate individual contaminant plumes. This approach was not used in the current study because (1) although the fluvial sediments in the La Pine study area are somewhat heterogeneous, the hydraulic conductivities of the hydrofacies that compose them fall within a relatively small range; and (2) the purpose of the model in this study was to estimate mean concentrations over relatively large areas as a tool for evaluating watershed-scale wastewater management approaches. Variability at the scale of individual model cells caused by uncertainty in the hydrogeologic model would not impose significant limitations on the use of the model.

\section{Hydraulic Conductivity}

Hydraulic conductivity is the characteristic of a porous medium that describes its ability to transmit water, and is expressed in units of length per unit time (for example, feet per day). The hydraulic conductivity of most geologic materials is vertically anisotropic; that is, hydraulic conductivity is greater in the horizontal direction than in the vertical direction. Simulation of three dimensional ground-water flow, as was done for this study, requires estimates of both the horizontal and vertical components of hydraulic conductivity. Horizontal hydraulic conductivity estimates were made for alluvial sediments and volcanic rocks using data from well-yield tests reported in 221 drillers' reports and slug tests done in 24 monitoring wells constructed for this study.

Transmissivity is another measure of the ability of porous materials to transmit water, and is equal to the product of hydraulic conductivity and the saturated thickness of the material. Transmissivity has units of length squared per time (for example, feet squared per day) and can be estimated using the Theis nonequilibrium equation and solving as reported in Vorhis (1979). Minimum data required from the well-yield test include pumping rate, drawdown, and time pumped. Only field-located wells with complete construction information that included well depth, casing diameter, and open or screened intervals were used in the analysis. The method of Vorhis (1979) yields a solution to the Theis equation in which transmissivity is expressed as a function of storage coefficient. 


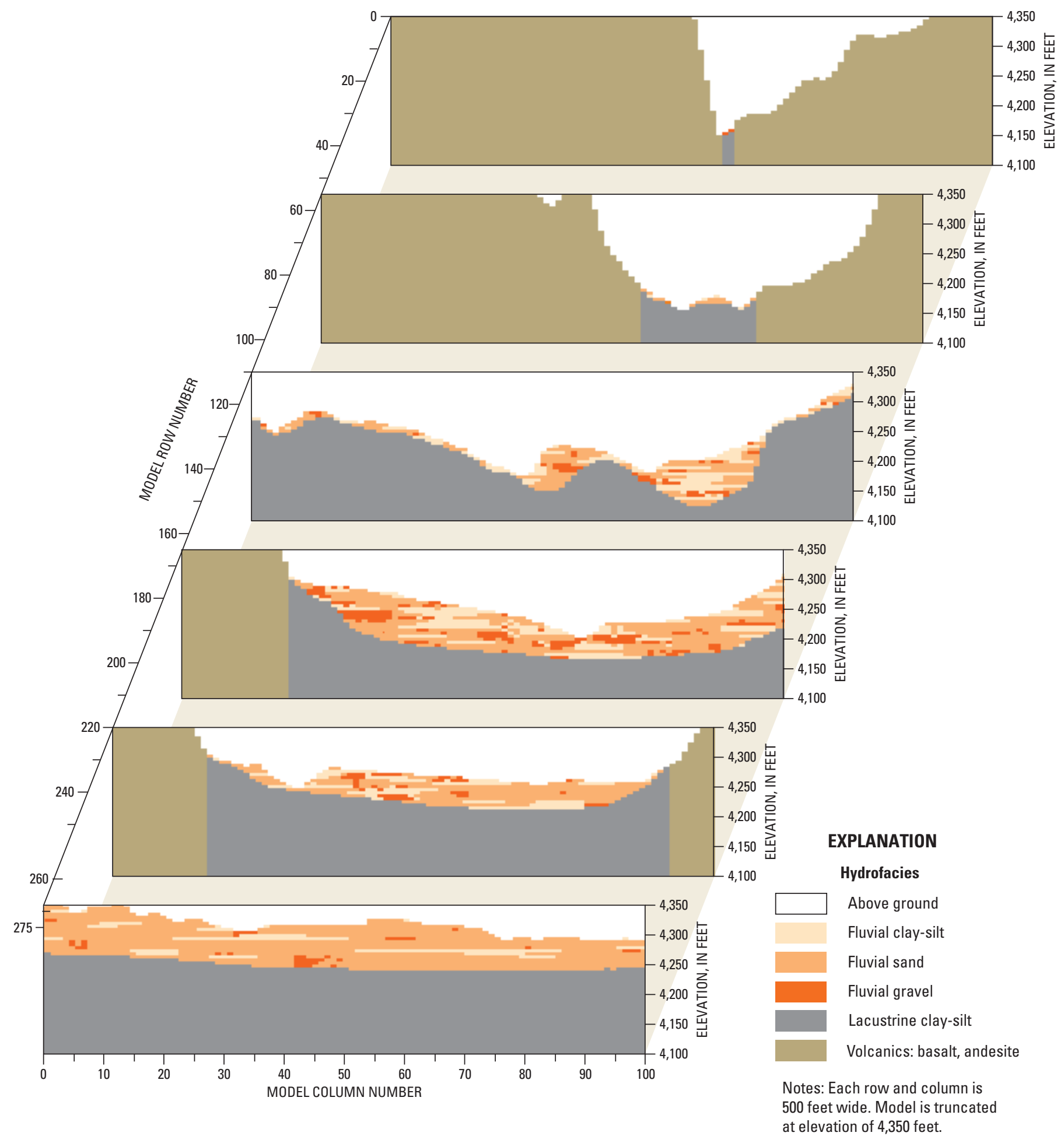

Figure 3. Three dimensional hydrogeologic model of the La Pine, Oregon, study area. 
Appropriate transmissivity values were selected by assuming a storage coefficient in the range normally assumed for confined aquifers (0.001) for deep wells and a storage coefficient (specific yield) in the range normally assumed for unconfined aquifers (0.10) for shallow wells. Wells were assigned unconfined storage coefficients if their open intervals did not extend more than $30 \mathrm{ft}$ below land surface in the northern part of the study area or $50 \mathrm{ft}$ in the southern part (south of the confluence of Paulina Creek and the Little Deschutes River) (fig. 1). Horizontal hydraulic conductivity was estimated at each well by dividing the estimated transmissivity by the length of the perforated and (or) uncased intervals of the well.

Horizontal hydraulic conductivities computed using the well-yield test data range from 0.15 to $2,500 \mathrm{ft} / \mathrm{d}$, with a geometric mean of $60 \mathrm{ft} / \mathrm{d}$ and median of $21 \mathrm{ft} / \mathrm{d}$. Gannet and others (2001) reported similar results from an analysis of 175 well-yield tests in the La Pine basin, in which the median transmissivity was $901 \mathrm{ft}^{2} / \mathrm{d}$. If a typical effective aquifer thickness of $50 \mathrm{ft}$ is assumed, the transmissivity reported by Gannett and others (2001) is equivalent to a hydraulic conductivity of $18 \mathrm{ft} / \mathrm{d}$. If well-yield data are reported accurately, the principal sources of error using this approach are head losses due to poor well construction and uncertainty in storage coefficient estimates. Sensitivity analysis showed that transmissivity, and therefore hydraulic conductivity, computed for a range of storage coefficients spanning three orders of magnitude $\left(10^{-1}\right.$ to $\left.10^{-4}\right)$ differed by an average of 50 percent. Uncertainty related to storage coefficient is not considered an important source of error. Overestimation of hydraulic conductivity can occur using this method if a well only partially penetrates a thick, homogeneous aquifer in which substantial vertical flow toward the well can occur. The effects of partial penetration are not likely to be important in data from wells in the La Pine study area because the heterogeneity of the alluvial sediments would limit vertical flow near the well.

Slug tests were done at 24 monitoring wells installed along two transects for this study. One transect was located in the northern part of the study area near South Century Drive and the other was located in the south-central part of the area near Burgess Road (fig. 1). The Burgess Road transect included tests of 17 wells at 6 sites and the South Century Drive transect included tests of 8 wells at 6 sites (table 2).

Table 2. Hydraulic conductivity estimates from slug test data from wells near LaPine, Oregon.

[Slug tests were conducted in April and September 2000. Latitude and L ongitude: in degrees, minutes, seconds; North American Datum of 1927. Altitude: referenced to National Geodetic Vertical Datum of 1929. A bbreviations: USGS: U.S. Geological Survey. Symbols: -, no data]

\begin{tabular}{|c|c|c|c|c|c|c|c|c|}
\hline $\begin{array}{c}\text { USGS site } \\
\text { identification } \\
\text { No. }\end{array}$ & $\begin{array}{l}\text { Project well } \\
\text { name }\end{array}$ & Local No. & $\begin{array}{c}\text { State } \\
\text { identification } \\
\text { No. }\end{array}$ & Latitude & Longitude & $\begin{array}{l}\text { Altitude } \\
\text { (feet) }\end{array}$ & $\begin{array}{l}\text { Depth } \\
\text { (feet) }\end{array}$ & $\begin{array}{c}\text { Hydraulic } \\
\text { conductivity } \\
\text { (feet per day }\end{array}$ \\
\hline 434202121301501 & Burgess 5.1 & $22.00 \mathrm{~S} / 10.00 \mathrm{E}-02 \mathrm{BBC} 01$ & DESC 52678 & $43^{\circ} 42^{\prime} 01.89^{\prime \prime}$ & $121^{\circ} 30^{\prime} 15.21^{\prime \prime}$ & $4,210.9$ & 23.9 & 15 \\
\hline 434202121301502 & Burgess 5.2 & $22.00 \mathrm{~S} / 10.00 \mathrm{E}-02 \mathrm{BBC} 02$ & DESC 52677 & $43^{\circ} 42^{\prime} 01.89^{\prime \prime}$ & $121^{\circ} 30^{\prime} 15.21^{\prime \prime}$ & $4,211.1$ & 36.9 & 24 \\
\hline 434202121301503 & Burgess 5.3 & $22.00 \mathrm{~S} / 10.00 \mathrm{E}-02 \mathrm{BBC} 03$ & DESC 52676 & $43^{\circ} 42^{\prime} 01.89^{\prime \prime}$ & $121^{\circ} 30^{\prime} 15.21^{\prime \prime}$ & $4,210.9$ & 49.0 & .6 \\
\hline 434203121305401 & Burgess 4.1 & $22.00 \mathrm{~S} / 10.00 \mathrm{E}-03 \mathrm{ABC} 01$ & DESC 52681 & $43^{\circ} 42^{\prime} 02.68^{\prime \prime}$ & $121^{\circ} 30^{\prime} 53.68^{\prime \prime}$ & $4,223.6$ & 26.5 & 18 \\
\hline 434203121305402 & Burgess 4.2 & $22.00 \mathrm{~S} / 10.00 \mathrm{E}-03 \mathrm{ABC} 02$ & DESC 52679 & $43^{\circ} 42^{\prime} 02.68^{\prime \prime}$ & $121^{\circ} 30^{\prime} 53.68^{\prime \prime}$ & $4,223.3$ & 33.2 & 58 \\
\hline 434203121305403 & Burgess 4.3 & $22.00 \mathrm{~S} / 10.00 \mathrm{E}-03 \mathrm{ABC} 03$ & DESC 52680 & $43^{\circ} 42^{\prime} 02.68^{\prime \prime}$ & $121^{\circ} 30^{\prime} 53.68^{\prime \prime}$ & $4,223.3$ & 49.3 & 6.4 \\
\hline 434206121311701 & Burgess 3.1 & $22.00 \mathrm{~S} / 10.00 \mathrm{E}-03 \mathrm{BBD} 01$ & DESC 52684 & $43^{\circ} 42^{\prime} 05.78^{\prime \prime}$ & $121^{\circ} 31^{\prime} 17.04^{\prime \prime}$ & $4,233.4$ & 22.5 & 11 \\
\hline 434206121311702 & Burgess 3.2 & $22.00 \mathrm{~S} / 10.00 \mathrm{E}-03 \mathrm{BBD} 02$ & DESC 52682 & $43^{\circ} 42^{\prime} 05.78^{\prime \prime}$ & $121^{\circ} 31^{\prime} 17.04^{\prime \prime}$ & $4,233.3$ & 30.5 & 45 \\
\hline 434206121311703 & Burgess 3.3 & $22.00 \mathrm{~S} / 10.00 \mathrm{E}-03 \mathrm{BBD} 03$ & DESC 52683 & $43^{\circ} 42^{\prime} 05.78^{\prime \prime}$ & $121^{\circ} 31^{\prime} 17.04^{\prime \prime}$ & $4,233.4$ & 38.6 & 55 \\
\hline 434206121312901 & Burgess 2.1 & $22.00 \mathrm{~S} / 10.00 \mathrm{E}-03 \mathrm{BBB} 01$ & DESC 52688 & $43^{\circ} 42^{\prime} 05.67^{\prime \prime}$ & $121^{\circ} 31^{\prime} 28.92^{\prime \prime}$ & $4,239.2$ & 23.1 & 17 \\
\hline 434206121312902 & Burgess 2.2 & $22.00 \mathrm{~S} / 10.00 \mathrm{E}-03 \mathrm{BBB} 02$ & DESC 52686 & $43^{\circ} 42^{\prime} 05.67^{\prime \prime}$ & $121^{\circ} 31^{\prime} 28.92^{\prime \prime}$ & $4,239.0$ & 30.0 & 23 \\
\hline 434206121312903 & Burgess 2.3 & $22.00 \mathrm{~S} / 10.00 \mathrm{E}-03 \mathrm{BBB} 03$ & DESC 52687 & $43^{\circ} 42^{\prime} 05.67^{\prime \prime}$ & $121^{\circ} 31^{\prime} 28.92^{\prime \prime}$ & $4,239.0$ & 36.3 & - \\
\hline 434206121312904 & Burgess 2.4 & $22.00 \mathrm{~S} / 10.00 \mathrm{E}-03 \mathrm{BBB} 04$ & DESC 52685 & $43^{\circ} 42^{\prime} 05.67^{\prime \prime}$ & $121^{\circ} 31^{\prime} 28.92^{\prime \prime}$ & $4,239.0$ & 52.3 & 7.7 \\
\hline 434213121295901 & Burgess 6.1 & $21.00 \mathrm{~S} / 10.00 \mathrm{E}-35 \mathrm{CDC} 1$ & DESC 53163 & $43^{\circ} 42^{\prime} 12.64^{\prime \prime}$ & $121^{\circ} 29^{\prime} 59.34^{\prime \prime}$ & $4,198.6$ & 14.7 & 9.0 \\
\hline 434213121295902 & Burgess 6.2 & $21.00 \mathrm{~S} / 10.00 \mathrm{E}-35 \mathrm{CDC} 2$ & DESC 53159 & $43^{\circ} 42^{\prime} 12.64^{\prime \prime}$ & $121^{\circ} 29^{\prime} 59.34^{\prime \prime}$ & $4,198.7$ & 45.0 & 1.3 \\
\hline 434213121324101 & Burgess 1.1 & $22.00 \mathrm{~S} / 10.00 \mathrm{E}-05 \mathrm{AAA} 01$ & DESC 52690 & $43^{\circ} 42^{\prime} 13.02^{\prime \prime}$ & $121^{\circ} 32^{\prime} 41.42^{\prime \prime}$ & $4,257.7$ & 34.7 & 64 \\
\hline 434213121324102 & Burgess 1.2 & $22.00 \mathrm{~S} / 10.00 \mathrm{E}-05 \mathrm{AAA} 02$ & DESC 52689 & $43^{\circ} 42^{\prime} 13.02^{\prime \prime}$ & $121^{\circ} 32^{\prime} 41.42^{\prime \prime}$ & $4,257.6$ & 50.5 & 33 \\
\hline 434910121275501 & Century 1.1 & $20.00 \mathrm{~S} / 11.00 \mathrm{E}-19 \mathrm{CCC} 1$ & DESC 53166 & $43^{\circ} 49^{\prime} 10.08^{\prime \prime}$ & $121^{\circ} 27^{\prime} 55.27^{\prime \prime}$ & $4,178.2$ & 12.1 & 12 \\
\hline 434910121275502 & Century 1.2 & $20.00 \mathrm{~S} / 11.00 \mathrm{E}-19 \mathrm{CCC} 2$ & DESC 53178 & $43^{\circ} 49^{\prime} 10.08^{\prime \prime}$ & $121^{\circ} 27^{\prime} 55.27^{\prime \prime}$ & $4,178.0$ & 68.3 & .3 \\
\hline 434945121273501 & Century 2 & $20.00 \mathrm{~S} / 11.00 \mathrm{E}-19 \mathrm{BDB}$ & DESC 53184 & $43^{\circ} 49^{\prime} 44.61^{\prime \prime}$ & $121^{\circ} 27^{\prime} 35.32^{\prime \prime}$ & $4,175.4$ & 11.1 & 8.8 \\
\hline 435007121272701 & Century 3 & $20.00 \mathrm{~S} / 11.00 \mathrm{E}-18 \mathrm{CDC} 1$ & DESC 53175 & $43^{\circ} 50^{\prime} 07.04 "$ & $121^{\circ} 27^{\prime 2} 27.31^{\prime \prime}$ & $4,173.9$ & 8.9 & 97 \\
\hline 435026121272101 & Century 4 & $20.00 \mathrm{~S} / 11.00 \mathrm{E}-18 \mathrm{CAA}$ & DESC 53185 & $43^{\circ} 50^{\prime} 25.67^{\prime \prime}$ & $121^{\circ} 27^{\prime} 20.64^{\prime \prime}$ & $4,174.1$ & 10.7 & 57 \\
\hline 435030121271401 & Century 5 & $20.00 \mathrm{~S} / 11.00 \mathrm{E}-18 \mathrm{ACC} 1$ & DESC 53160 & $43^{\circ} 50^{\prime} 29.75^{\prime \prime}$ & $121^{\circ} 27^{\prime} 14.15^{\prime \prime}$ & $4,172.9$ & 11.7 & 5.2 \\
\hline 435035121270801 & Century 6.1 & 20.00S/11.00E-18ACA1 & DESC 53164 & $43^{\circ} 50^{\prime} 34.68^{\prime \prime}$ & $121^{\circ} 27^{\prime} 08.15^{\prime \prime}$ & $4,171.9$ & 10.7 & 31 \\
\hline 435035121270802 & Century 6.2 & 20.00S/11.00E-18ACA2 & DESC 53158 & $43^{\circ} 50^{\prime} 34.68^{\prime \prime}$ & $121^{\circ} 27^{\prime} 08.15^{\prime \prime}$ & $4,171.8$ & 64.0 & .8 \\
\hline
\end{tabular}


The wells ranged from 8.9 to $68 \mathrm{ft}$ deep and were completed with 2-ft long screens. Falling- and rising-head tests were run with initial-head displacements of 1-2 ft. Test data were analyzed using the method of Bower and Rice (1976), with the assumptions that the effects of storage can be ignored and the change in saturated thickness of the aquifer is negligible. Horizontal hydraulic conductivities computed using the slug test data range from 0.3 to $98 \mathrm{ft} / \mathrm{d}$, with a geometric mean of $25 \mathrm{ft} / \mathrm{d}$ and median of $15 \mathrm{ft} / \mathrm{d}$ (fig. 4, table 2). The 10th and 90 th percentile values of hydraulic conductivity ( 0.6 and $60 \mathrm{ft} / \mathrm{d}$ ) span only two orders of magnitude which, even when considering that the tests selectively target coarser materials, suggest that hydraulic conductivity is relatively uniform in the area compared to some alluvial environments. The 10th-90th percentile range in hydraulic conductivity for the well-yield

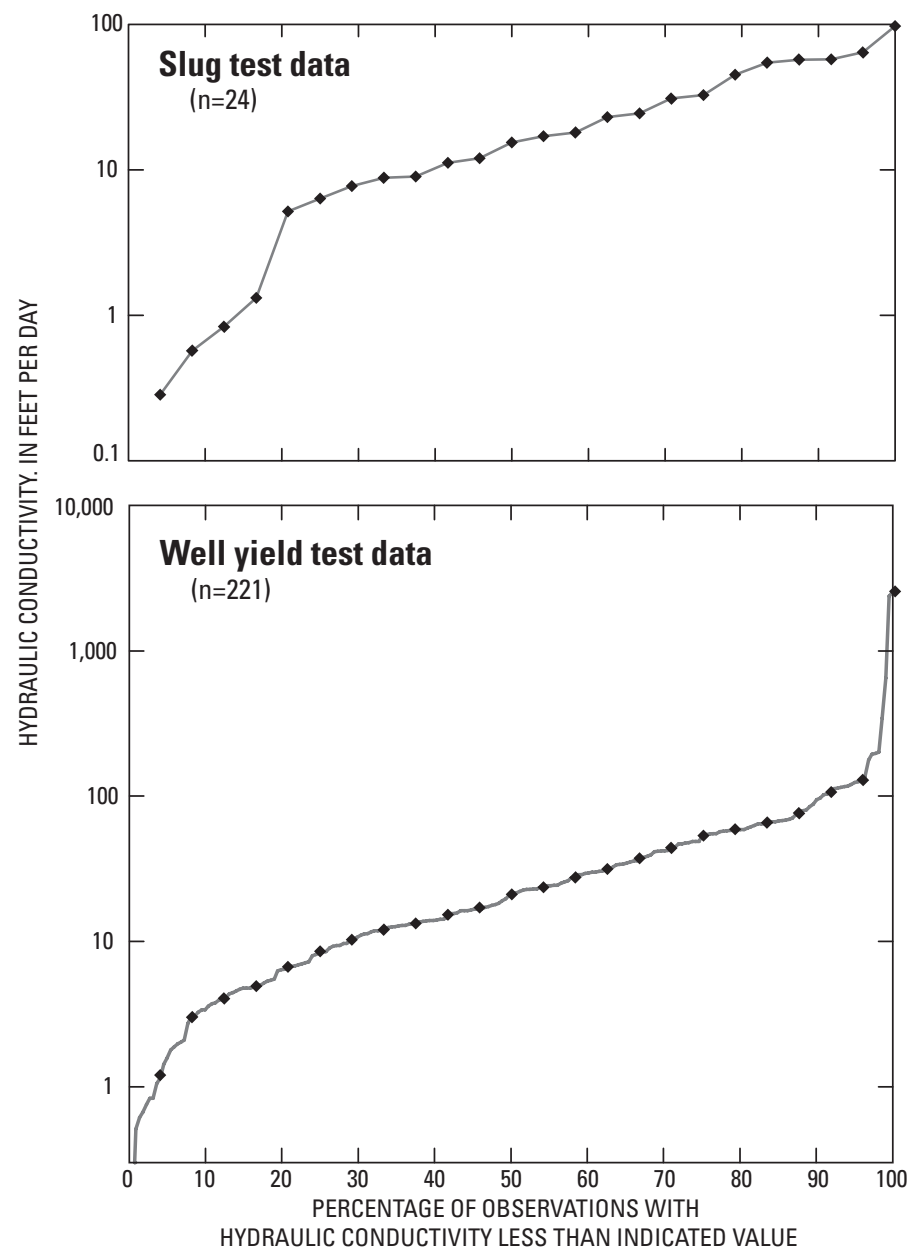

Figure 4. Distributions of estimated hydraulic conductivity values from slug tests and well-yield data. test data was 4 to $94 \mathrm{ft} / \mathrm{d}$. The 10 th percentile hydraulic conductivity is greater for this data set because the slug tests are conducted on water-supply wells selectively screened to the most permeable sediments and more thoroughly developed.

Median values from well-yield and slug test data were similar (21 and $15 \mathrm{ft} / \mathrm{d}$, respectively). Geometric mean hydraulic conductivity values were greater for the well-yield test data $(60 \mathrm{ft} / \mathrm{d})$ because several basalt wells included large (> $100 \mathrm{ft} / \mathrm{d}$ ) hydraulic conductivity values that skewed the mean (fig. 4). The agreement between the median values from both data sets indicates that both estimation methods provide good information on the hydraulic characteristics of the basinfill sediments.

\section{Ground-Water Recharge}

The shallow alluvial ground-water system in the study area is recharged primarily by infiltration of precipitation (rainfall and snowmelt), with lesser amounts resulting from lateral ground-water inflow and effluent from on-site wastewater systems. Gannett and others (2001) estimated ground-water recharge to the upper Deschutes River basin from infiltration of precipitation using a water balance model (Deep Percolation Model) developed by Bauer and Vaccaro (1987). The water balance model is based on empirical relations that quantify processes such as interception and evaporation, snow accumulation and melt, plant transpiration, and runoff. The model computes a complete daily water balance for the soil zone using measured precipitation and temperature and data describing land cover, vegetation, and soil properties. The water balance was computed within rectangular areas (cells), each with an area of $1.3 \mathrm{mi}^{2}$. A detailed description of application of the water balance model to the upper Deschutes River basin, including model input, is available in Boyd (1996) and a summary of the results for the entire upper basin is given in Gannett and others (2001).

Computed recharge from the water balance model was used to specify the initial spatial distribution of recharge within the boundaries of the simulation model. Based on calibration of simulation models in the La Pine area (see "Nitrate Fate and Transport Simulation Models"), the recharge distribution was reduced slightly; the final calibrated distribution is shown in figure 5 . The mean annual recharge distribution ranges from about 2 to $20 \mathrm{in} / \mathrm{yr}$ with the greatest recharge occurring in the upland areas; however, most of the model area lies at lower elevations adjacent to the Deschutes and Little Deschutes Rivers where mean annual recharge is about $2 \mathrm{in} / \mathrm{yr}$ (fig. 5). The mean annual recharge rate for the simulation model is $3.2 \mathrm{in} / \mathrm{yr}\left(58 \mathrm{ft}^{3} / \mathrm{s}\right)$. 


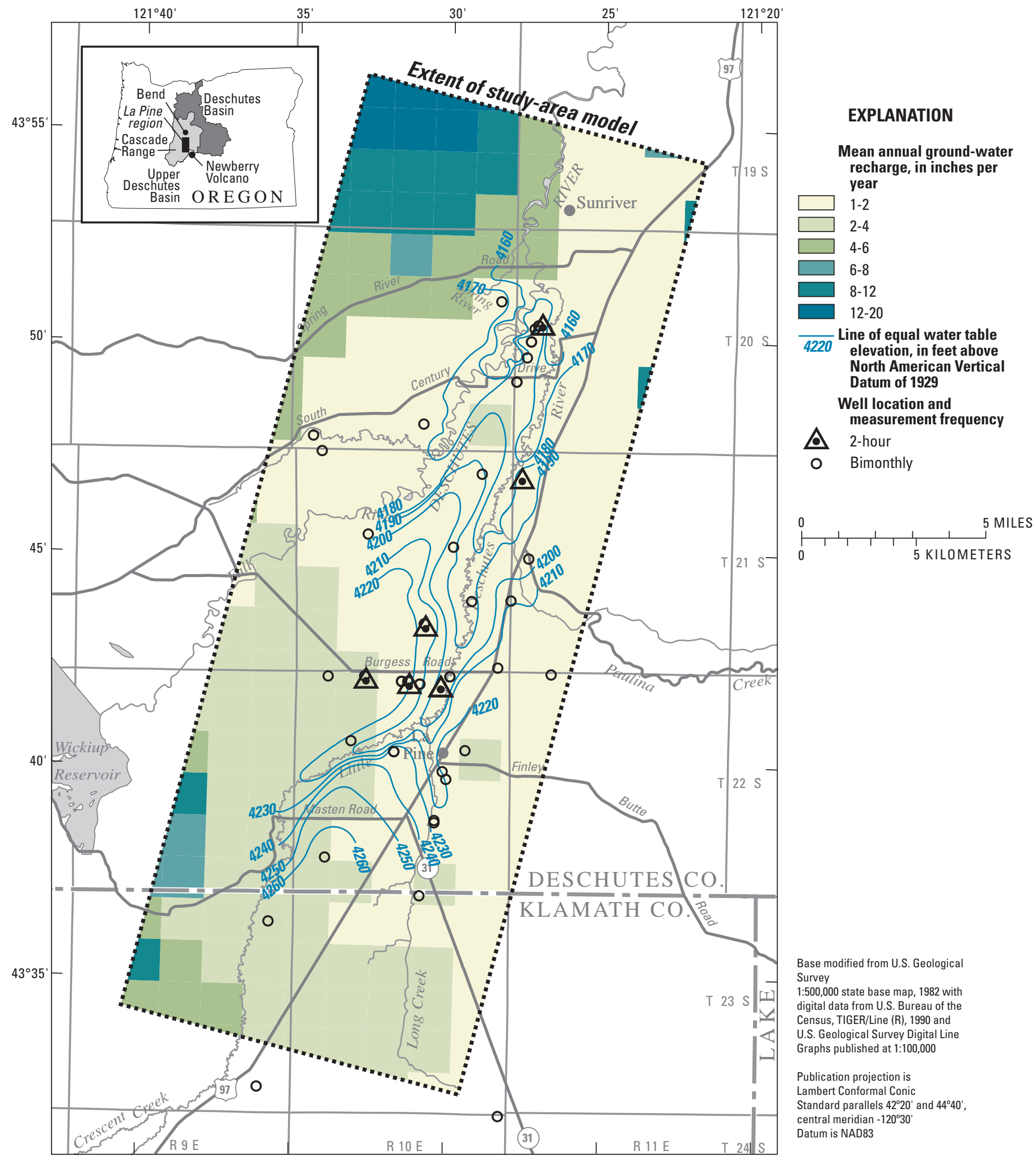

Figure 5. Distribution of mean annual recharge, water-table elevation contours (June 2000), and locations of monitoring wells in the La Pine, Oregon, study area. 
Effluent from on-site wastewater systems also contributes to recharge of the shallow ground-water system. The annual rate was estimated for 1999 when there were about 5,200 on-site wastewater systems in the study area. The average daily volume of effluent produced per system depends on the number of occupants and their water-use habits. Deschutes County monitored several on-site systems as part of the $\mathrm{La}$ Pine National On-Site Demonstration Project and determined that the average daily effluent volume was 45 gallons per day per person (B. Rich, written commun., Deschutes County, 2003). La Pine households averaged 2.55 persons in 2000 (U.S. Bureau of the Census, 2000), so each household would produce an average of $115 \mathrm{gal} / \mathrm{d}$. In 1999, about 5,200 on-site systems would have contributed $0.6 \mathrm{Mgal} / \mathrm{d},\left(0.9 \mathrm{ft}^{3} / \mathrm{s}\right)$, of recharge to the ground-water system.

\section{Ground-Water Flow}

Hydraulic head, or simply head, is a measure of the force that drives ground-water movement. Ground water flows from areas of high head to areas of low head. In an unconfined aquifer, such as the shallow alluvial deposits in the La Pine study area, the elevation of the water table represents the head at the upper surface of the aquifer. The rate of change in head with distance is called the hydraulic gradient, which is the slope of the water table. Ground water in deeper aquifers may be confined by lower permeability layers (for example, silt or clay). Ground water in confined aquifers may be under pressure, such that when a well penetrates the aquifer, ground water will rise in the well casing to levels above the top of the aquifer. The hydraulic gradient in the vertical direction is positive if head increases with depth, which indicates ground water is flowing upward; conversely, it is negative if head decreases with depth, and ground water is flowing downward.

Water-level measurements were made in 192 wells in June 2000. Water levels from 170 wells with screened intervals in the upper $100 \mathrm{ft}$ were used to construct a contour map of the water-table surface (fig. 5) used to calibrate the simulation model. Ground water in the shallow part of the system in the La Pine study area generally flows toward the rivers, which generally are gaining in the study area. Water-table contours also indicate that shallow ground water moves toward lowlying Long Prairie south of the La Pine core area (fig. 1).

The water table is typically within $20 \mathrm{ft}$ of land surface in the study area. The shallowest depths to water in the study area are along the lower reach of the Deschutes River and the entire Little Deschutes River. In many areas, the water table is within $5 \mathrm{ft}$ of land surface and seasonally inundates low lying areas adjacent to the streams during high flows in the spring.

Ground-water levels vary with time in response to changes in rates of recharge to and discharge from the groundwater system. To characterize seasonal and shorter variations, bi-monthly water-level measurements were made in 48 wells and digital recorders measured water levels every 2 hours in 9 additional wells. Most wells were monitored between March 2000 and December 2001; however, several wells in the bi-monthly network also were monitored between 1994 and 1998 as part of a previous study of the upper Deschutes basin (Gannett and others, 2001). Two long-term observation wells also are in the study area and are measured by the Oregon Water Resources Department (OWRD). These wells, one of which has been measured quarterly since 1945, provide insights on the effects of withdrawals (pumping), decadalscale climate variation, and other influences.

Three well hydrographs are shown in figure 6 to illustrate general observations regarding the response of ground-water levels to seasonal and long-term variation in recharge. Basic information for all wells included in the monitoring network is listed in table 3. Additional information for these wells, including the complete history of water-level data, is available from the USGS National Water Information System (NWIS) at http://waterdata.usgs.gov/or/nwis.

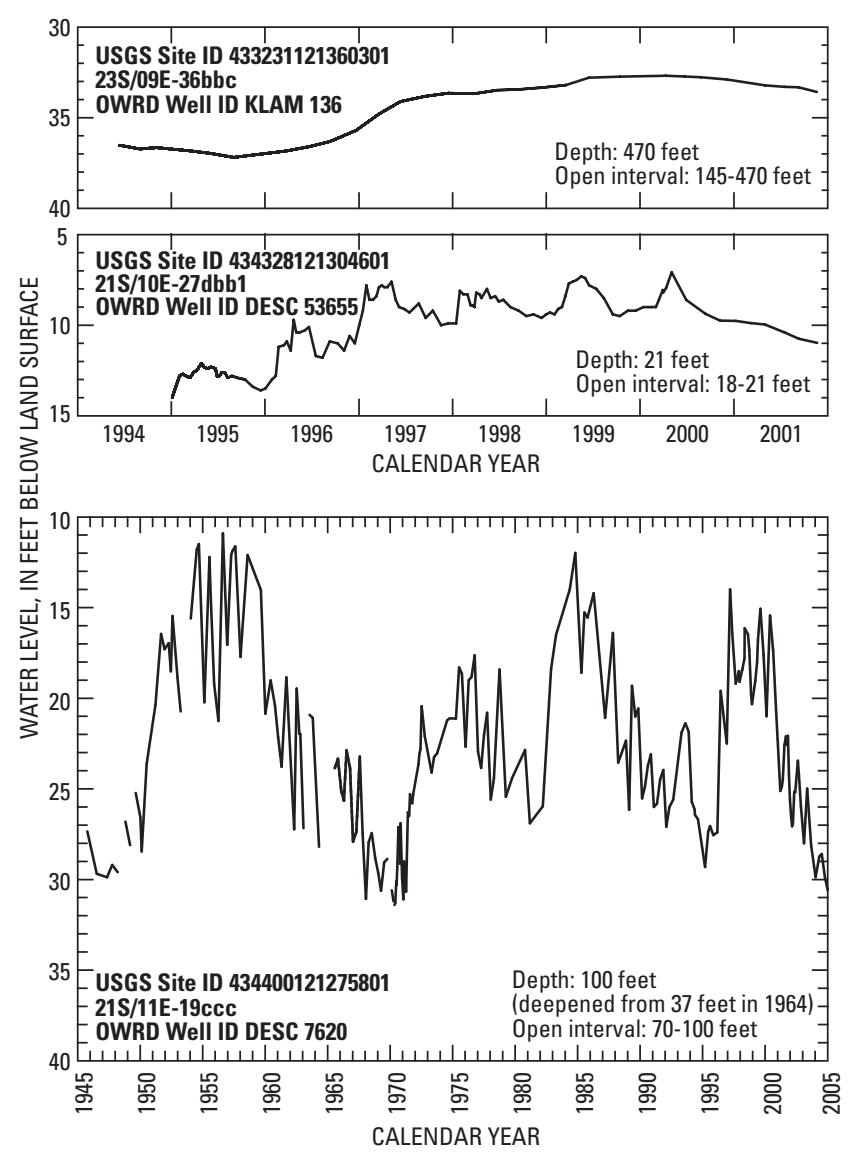

Figure 6. Water levels in selected wells in the La Pine, Oregon, study area. 
Table 3. Basin information for water-level monitoring wells in the La Pine, Oregon, study area.

[A bbreviations: USGS, U.S. Geological Survey. Frequency: B, bi-monthly; R, recorder (every 2 hours)]

\begin{tabular}{|c|c|c|c|}
\hline $\begin{array}{c}\text { State } \\
\text { identification } \\
\text { No. }\end{array}$ & $\begin{array}{c}\text { USGS site } \\
\text { identification No. }\end{array}$ & Local No. & Frequency \\
\hline DESC 52676 & 434202121301503 & $22.00 \mathrm{~S} / 10.00 \mathrm{E}-02 \mathrm{BBC} 03$ & $\mathrm{R}$ \\
\hline DESC 52677 & 434202121301502 & $22.00 \mathrm{~S} / 10.00 \mathrm{E}-02 \mathrm{BBC} 02$ & $\mathrm{R}$ \\
\hline DESC 52678 & 434202121301501 & $22.00 \mathrm{~S} / 10.00 \mathrm{E}-02 \mathrm{BBC} 01$ & $\mathrm{R}$ \\
\hline DESC 52684 & 434206121311701 & $22.00 \mathrm{~S} / 10.00 \mathrm{E}-03 \mathrm{BBD} 01$ & $\mathrm{R}$ \\
\hline DESC 52690 & 434213121324101 & $22.00 \mathrm{~S} / 10.00 \mathrm{E}-05 \mathrm{AAA} 01$ & $\mathrm{R}$ \\
\hline DESC 53158 & 435035121270802 & $20.00 \mathrm{~S} / 11.00 \mathrm{E}-18 \mathrm{ACA} 2$ & $\mathrm{R}$ \\
\hline DESC 53164 & 435035121270801 & $20.00 \mathrm{~S} / 11.00 \mathrm{E}-18 \mathrm{ACA} 1$ & $\mathrm{R}$ \\
\hline DESC 53656 & 434328121304603 & $21.00 \mathrm{~S} / 10.00 \mathrm{E}-27 \mathrm{DBB} 3$ & $\mathrm{R}$ \\
\hline DESC 53660 & 434657121274101 & $21.00 \mathrm{~S} / 11.00 \mathrm{E}-06 \mathrm{CBA}$ & $\mathrm{R}$ \\
\hline DESC 937 & 433756121335501 & 22S/10E-30DDD & B \\
\hline DESC 968 & 434810121305201 & $20 \mathrm{~S} / 10 \mathrm{E}-34 \mathrm{ABC}$ & B \\
\hline DESC 1450 & 433850121302301 & 22S/10E-22DDD & B \\
\hline DESC 1529 & 434700121285701 & $21 \mathrm{~S} / 10 \mathrm{E}-01 \mathrm{BCD}$ & B \\
\hline DESC 1727 & 434731121341001 & 20S/10E-31DDC & $\mathrm{B}$ \\
\hline DESC 6593 & 434516121295101 & $21.00 \mathrm{~S} / 10.00 \mathrm{E}-14 \mathrm{CDD}$ & B \\
\hline DESC 6959 & 434400121291401 & 21S/10E-23DDD & B \\
\hline DESC 7618 & 434501121272401 & 21S/11E-18CDA3 & B \\
\hline DESC 7620 & 434400121275801 & 21S/11E-19CCC & B \\
\hline DESC 7740 & 434217121263801 & $21.00 \mathrm{~S} / 11.00 \mathrm{E}-32 \mathrm{CCC}$ & B \\
\hline DESC 9173 & 433948121300101 & $22 \mathrm{~S} / 10 \mathrm{E}-14 \mathrm{CCA}$ & B \\
\hline DESC 9303 & 434752121343101 & $20.00 \mathrm{~S} / 10.00 \mathrm{E}-31 \mathrm{DBB}$ & B \\
\hline DESC 9314 & 434534121323801 & $21.00 \mathrm{~S} / 10.00 \mathrm{E}-16 \mathrm{BBB}$ & B \\
\hline DESC 9655 & 433959121300801 & $22 \mathrm{~S} / 10 \mathrm{E}-14 \mathrm{CBB} 02$ & B \\
\hline DESC 9889 & 434041121330701 & $22.00 \mathrm{~S} / 10.00 \mathrm{E}-08 \mathrm{DCC}$ & B \\
\hline DESC 50418 & 435104121282301 & $20.00 \mathrm{~S} / 10.00 \mathrm{E}-12 \mathrm{DCB}$ & B \\
\hline DESC 52533 & 433847121302301 & $22.00 \mathrm{~S} / 10.00 \mathrm{E}-22 \mathrm{DAA} 2$ & B \\
\hline DESC 52679 & 434203121305402 & $22.00 \mathrm{~S} / 10.00 \mathrm{E}-03 \mathrm{ABC} 02$ & B \\
\hline DESC 52680 & 434203121305403 & $22.00 \mathrm{~S} / 10.00 \mathrm{E}-03 \mathrm{ABC} 03$ & B \\
\hline DESC 52681 & 434203121305401 & $22.00 \mathrm{~S} / 10.00 \mathrm{E}-03 \mathrm{ABC} 01$ & B \\
\hline DESC 52682 & 434206121311702 & $22.00 \mathrm{~S} / 10.00 \mathrm{E}-03 \mathrm{BBD} 02$ & B \\
\hline DESC 52683 & 434206121311703 & $22.00 \mathrm{~S} / 10.00 \mathrm{E}-03 \mathrm{BBD} 03$ & B \\
\hline DESC 52685 & 434206121312904 & $22.00 \mathrm{~S} / 10.00 \mathrm{E}-03 \mathrm{BBB} 04$ & B \\
\hline DESC 52686 & 434206121312902 & $22.00 \mathrm{~S} / 10.00 \mathrm{E}-03 \mathrm{BBB} 02$ & $\mathrm{~B}$ \\
\hline DESC 52687 & 434206121312903 & $22.00 \mathrm{~S} / 10.00 \mathrm{E}-03 \mathrm{BBB} 03$ & $\mathrm{~B}$ \\
\hline DESC 52688 & 434206121312901 & $22.00 \mathrm{~S} / 10.00 \mathrm{E}-03 \mathrm{BBB} 01$ & B \\
\hline DESC 52689 & 434213121324102 & 22.00S/10.00E-05AAA02 & B \\
\hline DESC 53159 & 434213121295902 & $21.00 \mathrm{~S} / 10.00 \mathrm{E}-35 \mathrm{CDC} 2$ & B \\
\hline DESC 53160 & 435030121271401 & $20.00 \mathrm{~S} / 11.00 \mathrm{E}-18 \mathrm{ACC} 1$ & B \\
\hline DESC 53163 & 434213121295901 & $21.00 \mathrm{~S} / 10.00 \mathrm{E}-35 \mathrm{CDC} 1$ & B \\
\hline DESC 53166 & 434910121275501 & $20.00 \mathrm{~S} / 11.00 \mathrm{E}-19 \mathrm{CCC} 1$ & B \\
\hline DESC 53174 & 435007121272702 & $20.00 \mathrm{~S} / 11.00 \mathrm{E}-18 \mathrm{CDC} 2$ & $\mathrm{~B}$ \\
\hline DESC 53175 & 435007121272701 & $20.00 \mathrm{~S} / 11.00 \mathrm{E}-18 \mathrm{CDC} 1$ & B \\
\hline DESC 53177 & 435030121271402 & $20.00 \mathrm{~S} / 11.00 \mathrm{E}-18 \mathrm{ACC} 2$ & B \\
\hline DESC 53178 & 434910121275502 & 20.00S/11.00E-19CCC2 & B \\
\hline DESC 53184 & 434945121273501 & 20.00S/11.00E-19BDB & B \\
\hline DESC 53185 & 435026121272101 & 20.00S/11.00E-18CAA & B \\
\hline DESC 53651 & 434029121292401 & $22.00 \mathrm{~S} / 10.00 \mathrm{E}-11 \mathrm{DCC}$ & B \\
\hline DESC 53652 & 434026121314301 & $22.00 \mathrm{~S} / 10.00 \mathrm{E}-16 \mathrm{AAB} 1$ & $\mathrm{~B}$ \\
\hline DESC 53653 & 434026121314302 & $22.00 \mathrm{~S} / 10.00 \mathrm{E}-16 \mathrm{AAB} 2$ & B \\
\hline DESC 53655 & 434328121304601 & $21.00 \mathrm{~S} / 10.00 \mathrm{E}-27 \mathrm{DBB} 1$ & $\mathrm{~B}$ \\
\hline DESC 53657 & 434328121304602 & $21.00 \mathrm{~S} / 10.00 \mathrm{E}-27 \mathrm{DBB} 2$ & B \\
\hline DESC 53658 & 434212121335301 & $22.00 \mathrm{~S} / 10.00 \mathrm{E}-06 \mathrm{AAB}$ & B \\
\hline DESC 53659 & 433703121305101 & $22.00 \mathrm{~S} / 10.00 \mathrm{E}-34 \mathrm{DCC}$ & B \\
\hline DESC 53661 & 434226121282302 & 21.00S/10.00E-36ACD2 & B \\
\hline KLAM 136 & 433231121360301 & $23 \mathrm{~S} / 09 \mathrm{E}-36 \mathrm{BBC}$ & B \\
\hline KLAM 138 & 433152121281301 & $23 \mathrm{~S} / 10 \mathrm{E}-36 \mathrm{DDC}$ & B \\
\hline KLAM 51668 & 433625121354401 & 23.00S/09.00E-01DAC & B \\
\hline
\end{tabular}

Recharge to the ground-water system from infiltration of precipitation and snowmelt occurs primarily in winter and early spring when evaporation and transpiration losses are at a minimum and available moisture is at a maximum. When recharge to the ground-water system exceeds discharge, ground water is added to storage and water levels rise. The response of hydraulic head to the annual recharge pulse in the winter and early spring is attenuated in deeper wells, such as KLAM 136 (fig. 6); however, the annual recharge pulse causes seasonal water-level increases of as much as $5 \mathrm{ft}$ in shallow wells like DESC 53655 (fig. 6). The effects of longerterm variation in climate are evident in shallow and deep wells. Shallow (DESC 53655) and deep (KLAM 136) wells responded to the wet years from 1996 to 1998, although the response in the deep well was delayed and more gradual. The long-term monitoring well DESC 7620 is relatively shallow (100 ft) and shows that several wet and dry periods have occurred in the basin since the mid-1940s (fig. 6). The dry periods have an average length of 11 years. Based on the longterm hydrograph at well DESC 7620, water levels measured at wells in June 2000 and used to construct the water-table map in figure 5 are representative of long-term (1945-2005) mean water levels in the shallow part of the ground-water system.

\section{Ground-Water Discharge}

Ground water discharges to streams, springs, and wells, and by evapotranspiration. Discharge to streams and springs is the primary pathway for ground water to leave the shallow aquifers in the study area. Discharge to streams occurs as diffuse seepage through the streambed (below the water line), as discrete springs or spring complexes that form tributaries (for example, Fall River), and as seepage along the stream bank (above the water line). Evapotranspiration, which includes bare soil evaporation as well as transpiration by plants, is another mechanism for discharge where the water table is shallow. Pumping by wells also accounts for part of the overall discharge from the shallow aquifers in the study area.

\section{Streams and Springs}

The direction and rate of flow between ground water and streams is directly related to the direction and magnitude of the hydraulic gradient between the stream and the groundwater system. For ground water to discharge to a stream, the ground-water level must be greater than the stage of the stream. The rate of discharge to the stream is proportional to the difference between the ground-water level and the stream stage. 
Ground water discharge to streams and springs was estimated from gain-loss surveys of the Deschutes and Little Deschutes Rivers between October 1995 and October 2000. Gain-loss surveys, sometimes termed "seepage studies", are used to measure increases or decreases in streamflow between upstream and downstream measurement sites that can be attributed to exchange of water between the stream channel and the underlying ground-water system. The gain-loss surveys were conducted by measuring streamflow at intervals of 1 to $10 \mathrm{mi}$ on the Deschutes River between Wickiup Dam (river mile [RM] 226.7) and Benham Falls (RM 181.4) and on the Little Deschutes River between Wagon Trail Ranch (RM 43.0) and immediately upstream of the mouth (RM 0.5). Gaging stations are located below Wickiup Dam and at Benham Falls on the Deschutes River and at RM 26.7 on the Little Deschutes River (fig. 7). Tributary inflow to the Deschutes River was measured from Fall, Spring, and Little Deschutes Rivers, and tributary inflow to the Little Deschutes River was measured from Paulina Creek and Long Creek. The gain or loss to or from each reach was computed by summing the upstream and tributary inflow to the reach and deducting the downstream outflow and diversions. Any positive residual was assumed to be discharge from ground water; negative residuals were assumed to represent stream leakage (recharge) to ground water. Streamflow measurements and estimated gains and losses for surveys in October 1995, February 1996, March 2000, and October 2000, are listed in table 4.

The gain-loss surveys of the Deschutes River show net gains of 143 and $166 \mathrm{ft}^{3} / \mathrm{s}$ in 1996 and 2000. Most gains occur downstream of Harper's Bridge, RM 191.7, where large springs discharge near river level from basalt aquifers. Spring discharge to this reach was about $170-180 \mathrm{ft}^{3} / \mathrm{s}(15-20$ percent of flow) in the two gain-loss surveys. Between Wickiup Dam (RM 226.7) and Harper's Bridge the 1996 and 2000 surveys show a possible net loss of $10-40 \mathrm{ft}^{3} / \mathrm{s}$. Between Harper's Bridge and General Patch Bridge, surveys showed net losses of 54 and $24 \mathrm{ft}^{3} / \mathrm{s}$ in 1996 and 2000, respectively. Although the seepage results show apparent losses in this reach they are similar in magnitude to the estimated error of measurement (32-38 ft $3 / \mathrm{s})$. Other data (contours showing horizontal hydraulic head gradients toward the river and upward vertical gradients measured below the river bed) indicate that ground water discharges to the river in this reach and seepage data lack the accuracy to measure the gain in flow. Upstream of General Patch Bridge, the Deschutes River receives groundwater discharge of as much as $25 \mathrm{ft}^{3} / \mathrm{s}$, with most entering the river downstream of the La Pine State Recreation Area. The 10-mi reach upstream of Pringle Falls showed little or no ground-water interaction in 1996 and 2000.

Overall, little net gain or loss was measured in flow of the Deschutes River upstream of Harper's Bridge, relative to the total discharge of the river. This is probably due to the low permeability of the ash and tephra deposits that constitute much of the streambed and lack of major springs discharging directly to the channel in this reach. However, exchange between the river and the ground-water system may be occurring at a smaller scale that cannot be resolved by gain-loss surveys in which measurements are several miles apart. The multitude of meander loops likely are hydraulically connected by old channel deposits that may provide groundwater flow pathways where stream water can leave the channel and re-enter downstream.

The Little Deschutes River downstream of RM 43 showed net gains ranging from 6.7 to $19.8 \mathrm{ft}^{3} / \mathrm{s}$ in the gain-loss surveys conducted in October 1995, March 2000, and October 2000. All three surveys showed that the reach between Bridge Drive (RM 15.9) and South Century Drive (RM 5.5) received ground-water discharge; the gains in the reach ranged from 5.9 to $25.2 \mathrm{ft}^{3} / \mathrm{s}$ ( 0.6 to $2.4 \mathrm{ft}^{3} / \mathrm{s} / \mathrm{mi}$ ), although the measurement error was nearly equal to the apparent $25.2 \mathrm{ft}^{3} / \mathrm{s}$ gain in March 2000. Gains ranging from 2.9 to $28.5 \mathrm{ft}^{3} / \mathrm{s}\left(0.2\right.$ to $\left.1.8 \mathrm{ft}^{3} / \mathrm{s} / \mathrm{mi}\right)$ also were measured in the $16.3 \mathrm{mi}$ reach upstream of the gaging station (at RM 26.7). The reach from South Century Drive (RM 5.5) to just upstream of the mouth (RM 0.5) had little or no gain or loss in the October surveys (1995 and 2000); however, the March 2000 survey indicated a $35 \mathrm{ft}^{3} / \mathrm{s}$ loss in this reach.

Long Creek is an intermittent tributary to the Little Deschutes that drains the area between Highways 97 and 31 to the south of La Pine. This topographically low area probably is an abandoned channel of the Little Deschutes River. Aerial photography showing lush vegetation throughout summer indicates that this area has a shallow water table and likely is a ground-water discharge area. In a typical year, Long Creek flows until the water-table declines below the streambed in June-July and then remains dry until the water table rises in response to winter-spring recharge.

The October surveys probably were representative of average conditions (neutral or slight gains) on the lowermost reach of the Little Deschutes River, whereas the March 2000 survey probably was affected by high flows (about $300 \mathrm{ft}^{3} / \mathrm{s}$ ) that occurred during the seepage measurements. The area between the Deschutes River and Little Deschutes immediately upstream of their confluence is underlain by 10-15 ft of pumice, sand, and fine gravel that overlie a dense, low-permeability clay. The top of the clay is exposed in the banks of the Deschutes and Little Deschutes Rivers a few feet above the water surface at low flow. In late spring, groundwater seepage is visible on the bank at the contact between the sand and gravel and the clay. At high stream stage, as during the March 2000 survey, surface water would move from the channel into the exposed sand and gravel while the hydraulic gradient between the stream and ground water is temporarily reversed (stream stage is greater than the ground-water level). 


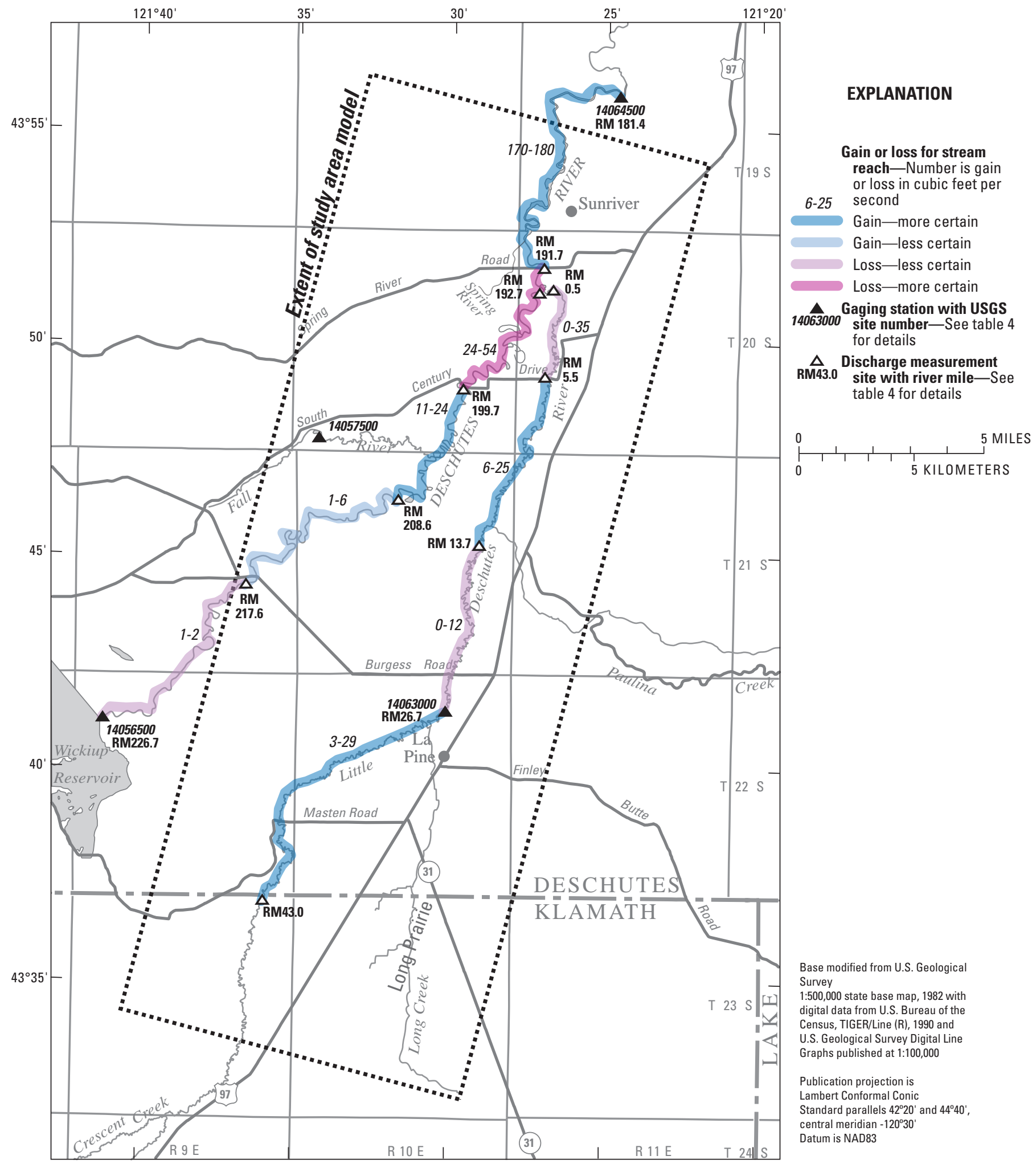

Figure 7. Gaining and losing reaches of the Deschutes and Little Deschutes Rivers and locations of measurement sites for gain-loss surveys between October 1995 and October 2000 in the La Pine, Oregon, study area. 


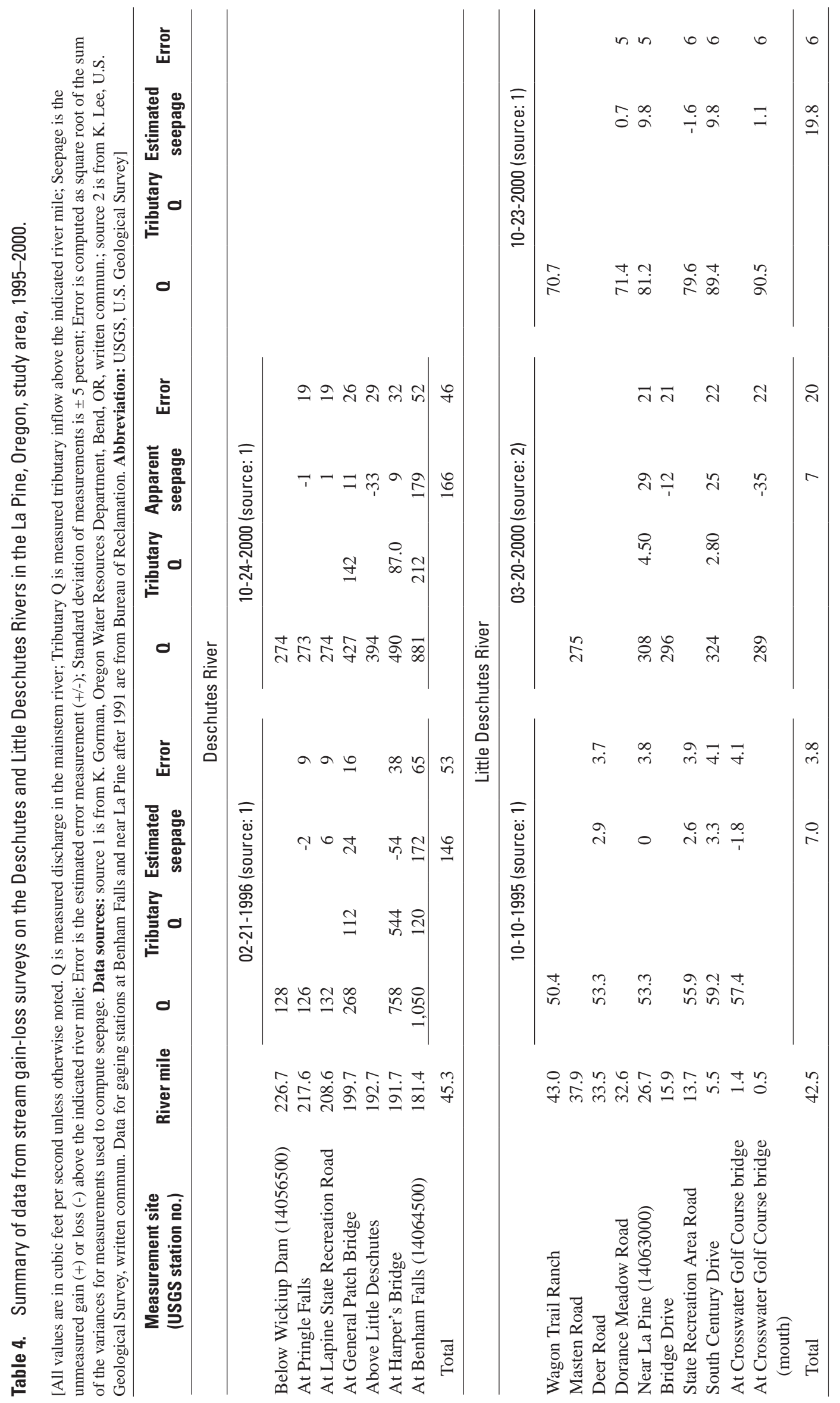


The surveys on the Little Deschutes River in October 1995 and October 2000 are surprisingly dissimilar considering that the discharge and measurement error were relatively low for each survey. The apparent net gain in October 2000 was nearly three times that measured in October 1995. The difference between the results of the two surveys likely is explained by the water-table elevation at the time of each survey. In 1995, the basin had undergone several years of less than-normal precipitation and ground-water levels had fallen by nearly $20 \mathrm{ft}$ over the previous decade in long-term observation well DESC 7620 (fig. 6). The lowering of the water table reduced the hydraulic gradient between the shallow ground water and the stream and, therefore, the ground-water discharge to the stream also was reduced. Between 1995 and 2000, ground-water levels recovered almost $15 \mathrm{ft}$, and based on the gain-loss surveys, ground-water discharge to the Little Deschutes River increased from 7 to nearly $20 \mathrm{ft}^{3} / \mathrm{s}$.

In October-November 2000, a survey was made of the vertical hydraulic head gradient between the shallow groundwater system and the Deschutes and Little Deschutes Rivers. The purpose of the survey was to identify the locations of gaining and losing reaches of the Little Deschutes and Deschutes Rivers at a more detailed scale than possible using the gain-loss surveys in which discharge measurements were made at locations separated by as much as $10 \mathrm{mi}$. Hydraulic gradient alone cannot be used to determine the volumetric rate of flow between a stream and the aquifer. Stream-channel profiles and bed lithology data (appendix A) also were collected during the survey and later used to estimate the stream bed conductance parameters required by the simulation model. The simulation model was used to estimate the rate of ground-water flow into or out of the stream; the simulated rates were compared with estimates from the seepage surveys during model calibration. Head gradient measurements were made at 12 sites on the Deschutes River between RM 192.5 and RM 218.4 and 20 sites on the Little Deschutes River between RM 2.0 and RM 42.6 (appendix A). The average distance between head gradient measurements was 2 river miles. Measurements were made using a portable hydraulic potentiometer that was driven 1-3 ft into the streambed. The relative head difference between the stream and ground water was measured to the nearest $0.01 \mathrm{ft}$ using a manometer. The design of the potentiometer and details on the procedure for measuring head gradients is given in Winter and others (1988). The dimensionless vertical hydraulic head gradient was computed at each location by dividing the head difference (ground-water level minus stream stage) by the depth of the center of the potentiometer screen below the stream bed.

Ground-water discharge was indicated at 18 of 20 measurement sites on the Little Deschutes River and at all 12 sites on the Deschutes River (appendix A). Vertical hydraulic gradients ranged from -0.003 to 0.075 on the Little Deschutes River (negative gradients indicate downward flow from the river) and 0.010 to 0.060 on the Deschutes River. All gradients were upward (indicating ground-water discharge to the river) except for two sites on the Little Deschutes River (RM 28.1 and 29.5; fig. A1, table A1) where neutral or slight downward gradients were measured.

\section{Evapotranspiration}

Ground-water discharge to the atmosphere can occur by evaporation from bare soil and transpiration from the leaves of phreatophytes (plants whose roots draw water from the saturated zone). The rate of evaporation from bare soil diminishes rapidly with increasing depth to the water table and is negligible if the water table is more than $10 \mathrm{ft}$ below land surface (Brutsaert, 1982, p. 236). Transpiration rates are dependent on the type and density of phreatophytes, climatic conditions, quality of water, and depth to water (Robinson, 1958 , p. 16). These processes usually are considered together and referred to as evapotranspiration, or ET.

In June 2000, the water table was within $10 \mathrm{ft}$ of land surface over an area of about $22 \mathrm{mi}^{2}$. The potential ET (PET) rate is the maximum possible rate for the local climate conditions if water is nonlimiting. As part of a regional ground-water budget, Gannett and others (2001) estimated that the PET for the saturated zone in the La Pine study area was $22 \mathrm{in} / \mathrm{yr}$, which is equivalent to about $1.6 \mathrm{ft} / \mathrm{s} / \mathrm{mi}^{2}$. This rate would occur only if the water table was at or near land surface with full coverage of phreatophytes. Under these conditions, the maximum rate of ground-water discharge from the study area by ET would be $35 \mathrm{ft}^{3} / \mathrm{s}$. Because the water table is not at land surface and the coverage of phreatophytes is considerably less than 100 percent, a more reasonable estimate of total ET from the study area is in the range of 10 to $20 \mathrm{ft}^{3} / \mathrm{s}$.

\section{Wells}

Eleven public-water supply systems (Oregon Department of Human Services, 2005) served about 1,650 people in the study area in 2000. The largest water purveyor, the La Pine Water District, serves 800 residents in the central core area of La Pine. A private water system serves about 350 residents of neighborhoods north of South Century Drive, between the Deschutes and Little Deschutes Rivers. Several other small water systems serve about 500 residents of mobile home and recreational vehicle parks scattered throughout the study area. About 12,350 residents, about 90 percent of the population, obtained their water from individual, privately-owned wells in 2000. Local water use data for self-supplied rural residents in the study area was not available. Mean per capita withdrawals for self-supplied rural domestic use in Oregon is estimated to be $110 \mathrm{gal} / \mathrm{d}$ (Hutton and others, 2004); however, given the limited amount of irrigated landscaping in the La Pine 
area, this value probably is not applicable. Deschutes County monitored wastewater effluent discharge at homes in the area as part of the La Pine Demonstration Project and determined the average per capita rate was $45 \mathrm{gal} / \mathrm{d}$ (Oregon Department of Environmental Quality, 2004b). To estimate domestic well withdrawals, it was assumed that outside water use was equal to 25 percent of total use, making the total per capita withdrawal rate equal to $60 \mathrm{gal} / \mathrm{d}$. Assuming this rate for each of the 14,000 residents, about $0.84 \mathrm{Mgal} / \mathrm{d}\left(1.3 \mathrm{ft}^{3} / \mathrm{s}\right)$ were withdrawn in 2000. Infiltration of effluent from on-site wastewater systems returns is about $45 \mathrm{gal} / \mathrm{d}$ per capita $(0.63 \mathrm{Mgal} / \mathrm{d}$ total $)$ to the ground-water system as recharge at the water table, resulting in net withdrawals of $0.21 \mathrm{Mgal} / \mathrm{d}$ $\left(0.32 \mathrm{ft}^{3} / \mathrm{s}\right)$.

\section{Nitrogen Fate and Transport}

As part of this study, Hinkle and others (2007a) applied geochemical and isotopic tools at various scales to provide a framework for understanding aquifer-scale nitrate source, transport, and fate. (Other wastewater contaminants, such as viruses and pharmaceuticals, were evaluated by Hinkle and others [2005].) The conceptual model resulting from this work was used to develop the transport simulation model.

Nitrogen concentration data, tracer-based apparent ground-water ages, ratios of $\mathrm{N} / \mathrm{Cl}^{-}, \mathrm{N}$ isotope data, and ground-water flow directions indicate that on-site wastewater effluent is the only significant anthropogenic nitrogen source to shallow ground water in the area. High concentrations of ammonium were measured in samples from deep ground water. Nitrogen isotopes, $\mathrm{N} / \mathrm{Cl}^{-}$and $\mathrm{N} / \mathrm{C}$ ratios, tritiumage data, and hydraulic-head gradients support a natural, sedimentary organic matter source for the high concentrations of ammonium in the deep aquifer, as opposed to an origin from on-site wastewater derived nitrogen.

Most residential development in the La Pine area has occurred since 1960, with accelerated growth during 1990-2005. As a result, loading of nitrate from on-site wastewater systems is a relatively recent phenomenon that, in combination with low ground-water recharge rates, has resulted in high concentrations of nitrate near the water table. Low recharge rates and flow velocities have, for now, generally restricted nitrate occurrence to discrete plumes within 20-30 ft of the water table. Concentrations of nitrate typically are low in deeper, older ground water due to the nature and timing of nitrate loading and transport, and to loss by denitrification. Denitrification is the process of reducing nitrate into gaseous nitrogen. The process is performed by bacteria when dissolved oxygen (which is a more favorable electron acceptor) is depleted, and bacteria turn to nitrate in order to oxidize organic carbon or other electron donors.
Denitrification was identified as an important geochemical process in the study area by Hinkle and others (2007a), who reported various supporting evidence, including nitrate/chloride relations, presence of excess $\mathrm{N}_{2}$ enriched in ${ }^{15} \mathrm{~N}$, presence of $\mathrm{N}_{2} \mathrm{O}$, and nitrate losses within a framework of progressively reduced ground water, reflecting classical geochemical evolution. Ground water in the study area evolves from oxic to increasingly reduced conditions with increasing depth below the water table. Suboxic conditions are achieved in 15-30 years, and the boundary between oxic and suboxic ground water is sharp. Nitrate is denitrified near the oxicsuboxic boundary.

The denitrification process was simulated by specifying the location of the oxic-suboxic boundary within the groundwater system and applying the assumption that nitrate is rapidly converted to nitrogen gas as it is transported across the boundary. The location of the boundary was mapped within the study-area using data from 256 wells where dissolved oxygen concentrations were available (Hinkle and others, 2007a). Oxic ground water was defined as water with dissolved oxygen concentrations greater than to $0.5 \mathrm{mg} / \mathrm{L}$. The boundary between oxic and suboxic water was constrained at each sampling site using information on the depth to the water table and well construction. The elevation of the oxic/suboxic boundary cannot be exactly determined at wells; however, the elevation can be constrained if depth to the water table and the top of the screened interval of the well are known. The presence of suboxic water indicates that the boundary lies above the top of the screened interval and the presence of oxic water indicates that the boundary lies below the top of the screened interval. In the latter case, the well may yield a mixture of oxic and suboxic water if the boundary lies within the screened interval, or the water may be entirely oxic if the boundary lies below the screened interval. In areas where data were sparse, an understanding of general patterns of occurrence of oxic and suboxic water was used to infer the location of the boundary. The general absence of oxic water below a depth of $50 \mathrm{ft}$ below the water table helped constrain the depth over large parts of the study area. Similarly, the general absence of suboxic water in ground water within $10 \mathrm{ft}$ of the water table constrained the minimum thickness of the oxic part of the aquifer. However, one limitation of the data was the absence of wells in near-stream areas to constrain the boundary location. The thickness of the oxic part of the aquifer was contoured (fig. 8) and used to specify the location of the oxic-suboxic boundary in the transport model. The thickness of the oxic part of the aquifer decreases as ground water moves toward discharge areas along the Deschutes River, Little Deschutes River, and Long and Paulina Creeks. This is consistent with the aging of ground water as it moves along flow paths terminating at surface-water features in the area. Details of the implementation of the boundary are presented in the description of the simulation model. 


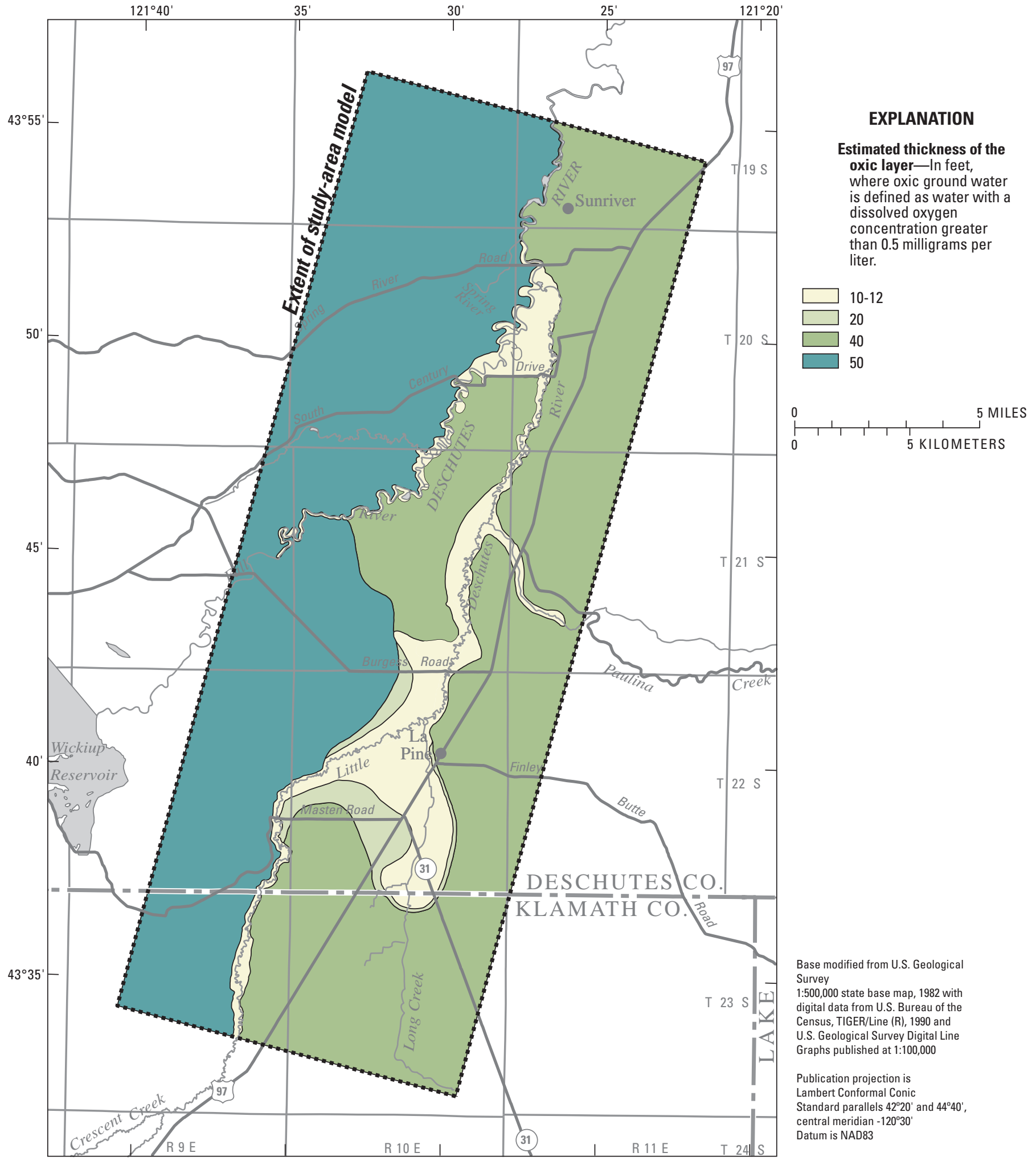

Figure 8. Estimated thickness of oxic ground-water layer in the shallow aquifer in the La Pine, Oregon, study area. 


\section{Nitrogen Loading from On-Site Wastewater Systems}

The annual rate of nitrogen loading to the shallow aquifer system from on-site wastewater systems was estimated for 1960-2005. The simulation model was run for 1960-99 using the estimated annual loading rates as input and simulated nitrate concentrations were compared with measured concentrations. Previous investigations (Century West Engineering, 1982; Oregon Department of Environmental Quality, 1994) have concluded that the only significant anthropogenic source of nitrogen to the groundwater system in the La Pine study area is effluent from on-site wastewater systems. As previously described, Hinkle and others (2007a) also cite several lines of geochemical evidence supporting the conclusion that on-site wastewater systems are the dominant anthropogenic nitrogen source. This conclusion also is consistent with the low level of agricultural activity, limited number of livestock, and infrequent use of turf (and therefore fertilizer) in residential landscaping in the study area (Century West Engineering, 1982; Oregon Department of Environmental Quality, 1994; Hinkle and others, 2007a).

Annual nitrogen loading to ground water from on-site wastewater-system effluent was estimated for each tax lot in the study area annually from 1960 to 1999 . The population of the study area prior to 1960 was sufficiently small that nitrogen loading was considered negligible. Nitrogen loading estimates were compiled by tax lot, but later aggregated across larger areas for input to the simulation model. Sources considered for nitrogen loading estimates included residential, schools, motels, restaurants, and recreational vehicle and trailer parks. Tax lot data (location, property class, improvement class, year built) were provided by Deschutes County (Tim Berg, Deschutes County Department of Community Development, written commun., 2001) and Klamath County (Jim McClellan, Klamath County Department of Management Information Services, written commun., 2001). Nitrogen loading was assumed to begin when lots were developed and end when lots were connected to a centralized sewer system (see areas served by centralized sewers in figure 1). Dates of sewer installation were provided by ODEQ (Dick Nichols, ODEQ, written commun., 2001) and La Pine Special Sewer District (Andy Newton, La Pine Special Sewer District, oral commun., 2001). Nitrogen loads were calculated for each of the approximately 5,200 lots that were developed and used on-site wastewater systems in 1999.

Nitrogen loading for homes was assumed to equal the product of the average number of persons per household (2.55 persons/household in the study area [U.S. Bureau of the Census, 1960, 1970, 1980, 1990, 2000]); average volume of effluent discharged to the on-site system by each person (45 gal/person/d or $170 \mathrm{~L} /$ person/d [U.S. Environmental Protection Agency, 1980; Oregon Department of Environmental Quality, 2004b]), and average nitrogen concentration in on-site wastewater system effluent $(61 \mathrm{mg}$ N/L in the study area [B. Rich, ODEQ, written commun.,
2001]). Nitrogen discharged from on-site wastewater systems also was assumed to be completely oxidized to nitrate in the unsaturated zone beneath the drain field. Using these assumptions, the estimated potential average nitrogen loading per home is $21 \mathrm{lb} \mathrm{N} / \mathrm{yr}(9.7 \mathrm{~kg} \mathrm{~N} / \mathrm{yr})$.

The potential for nitrogen loss in the unsaturated zone was evaluated by sampling packed-bed (sand) filter on-site systems in the upper Deschutes Basin. Inflow to and outflow from the sand filters was sampled at 15 sites in two networks. The first network consisted of 10 sand filters, installed 0.9 to 9.1 years prior to sampling. The second network consisted of 5 new sand filters. The first network was sampled once (October 2001) and the second network was sampled approximately bi-monthly for 3 years after installation (October 2000 November 2003). Samples were analyzed by ODEQ as part of the La Pine NDP for nitrate, ammonium, total Kjeldahl nitrogen, and chloride. Nitrogen concentrations were adjusted for dilution and evaporation using chloride concentrations. The adjusted nitrogen concentrations from the first sand-filter network indicated median and mean nitrogen losses of 31 percent and 29 percent, respectively (ODEQ, unpub. data, 2004). Data from the second network showed that the sand filters underwent a period of maturation after installation. Using data from samples collected more than one year after installation, adjusted nitrogen concentrations from the second sand-filter network indicated median and mean nitrogen losses of 11 percent (Oregon Department of Environmental Quality, 2004b). The artificial unsaturated zone created by a sand-filter on-site system would be expected to function much like the natural unsaturated zone beneath standard on-site systems in the study area and similar rates of nitrogen loss would be expected beneath standard and sand-filter on-site wastewater systems. Based on the range of nitrogen loss indicated in the sand-filter sampling study (approximately 10 to 30 percent), nitrogen losses in the unsaturated zone were assumed to average 25 percent for conventional on-site systems (including standard, pressure-distribution, and sandfilter systems) for computing loading rates. Nitrogen loss of 25 percent in the unsaturated zone would reduce the assumed nitrogen concentration of effluent as it enters the saturated part of the ground-water system (water table) from $61 \mathrm{mg} \mathrm{N} / \mathrm{L}$ to $46 \mathrm{mg} \mathrm{N} / \mathrm{L}$. For the same effluent volume, the resulting annual nitrogen loading to the ground-water system would be reduced from $21 \mathrm{lb} \mathrm{N} / \mathrm{yr}(9.7 \mathrm{~kg} \mathrm{~N} / \mathrm{yr})$ to $16 \mathrm{lb}$ N/yr (7.3 kg N/yr).

Nitrogen loading estimates were further adjusted to account for seasonal residency. For many years a significant number of homes in the study area were second homes or vacation rentals occupied only part of the year. In 1980, about 46 percent of the population in the study area was seasonal (Century West Engineering, 1982). Seasonal residents made up an estimated 20 percent of study area population in 2000 (Keven Bryan, La Pine Postmaster, oral commun., 2000; Carla Crume, La Pine Chamber of Commerce, oral commun., 2000). To account for seasonal residents in the estimates of nitrate loading it was assumed that (1) a seasonal resident did not occupy their home for 6 months of the year, (2) seasonal 
residents were 46 percent of the population from 1960 to 1980, and (3) the percentage of seasonal residents decreased from 46 to 20 percent between 1980 and 1999. Adjusted for seasonal residency, residential nitrate loading estimates ranged from 12 to $14 \mathrm{lb} / \mathrm{yr}$ (5.6 to $6.5 \mathrm{~kg} / \mathrm{yr}$ ) per home between 1960 and 1999.

About 9,300 residential lots in the study area depend (or will depend) on on-site systems for wastewater disposal. Nearly 8,200 lots are in Deschutes County and the remaining 1,100 lots are in Klamath County. About 1,800 additional undeveloped lots in Deschutes County may not be suitable for on-site wastewater systems due to extremely shallow watertable conditions (Tim Berg, Deschutes County Community Development Department, written commun., November 2005). Another 485 lots in Deschutes County will be served by a central sewer system scheduled to be completed in 2008 and are not included in these totals (B. Rich, Deschutes County Community Development Department, written commun., November 2005). As of 1999, homes with on-site systems had been built on 4,800 and 390 lots in Deschutes County and Klamath County, respectively. Assuming an average nitrogen loading rate of $14 \mathrm{lb} / \mathrm{yr}(6.5 \mathrm{~kg} / \mathrm{yr})$ per home, total residential loading in 1999 was 74,000 lb/yr (33,750 kg/yr). According to Deschutes County records, about 1,000 new homes were built between 2000 and 2005; this represents about 26 percent of the 2000 inventory of 3,900 lots in the Deschutes County part of the study area. Building data were not available for the Klamath County part of the study area for 2000-2005, however if the same growth rate is assumed, an additional 180 new homes would have been built during this period. The estimated number of homes in the study area in 2005 was 6,370 with nitrogen loading of $91,000 \mathrm{lb} / \mathrm{yr}(41,400 \mathrm{~kg} / \mathrm{yr})$. The remaining inventory of lots suitable for on-site systems in 2005 was 2,930, which could potentially add 42,000 lb/yr $(19,000 \mathrm{~kg} / \mathrm{yr})$ of nitrogen loading from on-site systems. These residential loading estimates are based on the assumption that 20 percent of residents were seasonal in 1999 and 2005. If all residents were full-time, the average nitrogen loading per home would be $16 \mathrm{lb} / \mathrm{yr}(7.3 \mathrm{~kg} / \mathrm{yr})$ and the total loading from on-site systems after all lots $(9,300)$ were developed would be about $150,000 \mathrm{lb} / \mathrm{yr}(67,900 \mathrm{~kg} / \mathrm{yr})$, or about 164 percent of the 2005 estimate.

As with homes, nitrogen loading for schools, motels, restaurants, and recreational vehicle and trailer parks was assumed to equal the product of the number of people using the facilities, average volume of effluent generated per person, and the average nitrogen concentration in on-site system effluent (also assumed to be $46 \mathrm{mg} \mathrm{N} / \mathrm{L}$ for these facilities). In most instances, estimates of the number of people served by on-site systems in study area schools, motels, restaurants (data in terms of restaurant seats), and recreational vehicle and trailer parks were obtained from employees at the facilities and from the Deschutes County Department of Environmental Health. Data could not be obtained directly from some motels and recreational vehicle and trailer park sites; in these instances, data obtained from similar sites were applied. Average volumes of effluent generated in schools were reported to be $3.2 \mathrm{gal} / \mathrm{d}(12 \mathrm{~L} / \mathrm{d})$ per elementary school student and $5.3 \mathrm{gal} / \mathrm{d}(20 \mathrm{~L} / \mathrm{d})$ per middle school student (John Rexford, Operations Manager, Bend-La Pine Public School District, written commun., 2001); volumes for high school students were assumed to be the same as for middle school students. A volume of $14 \mathrm{gal} / \mathrm{d}(53 \mathrm{~L} / \mathrm{d})$ per restaurant seat (obtained by adjusting the value reported by Frimpter and others [1990], to estimated study area restaurant use) was used in estimates for restaurants. A volume of $34 \mathrm{gal} / \mathrm{d}(130 \mathrm{~L} / \mathrm{d})$ per person was used for motels (Tchobanoglous and Burton, 1991), and $45 \mathrm{gal} / \mathrm{d}$ (170 L/d) per person (same as for homes) for recreational vehicle and trailer parks. In 1999, nitrogen loading from nonresidential sources totaled about 6,600 lb/yr $(3,000 \mathrm{~kg} / \mathrm{yr})$.

Annual and cumulative nitrogen loading to the groundwater system from 1960 through 2005 are shown in figure 9. Annual rates for 1960-99 were estimated using the method described above. The 2005 loading rate was based on updated information on the number of homes built as of 2005; the 2000-2004 loading rates were estimated by assuming that the number of homes (and loading) increased linearly during the period and nonresidential loading remained constant at the 1999 rate of 6,600 lb/yr (3,000 kg/yr). Loading increased at a moderate rate as the population grew from 1960 to the mid-1970s. In the late 1970s, a surge in building (and nitrogen loading) occurred prior to enactment of more restrictive rules for on-site systems. Construction of a sewer system for the central business district of La Pine in 1989 caused only a minor reduction in overall nitrogen loading that was followed by rapid population growth and concurrent loading into the 2000s. In 2005, the cumulative mass of nitrogen added to the ground-water system since 1960 was more than 2 million pounds $(900,000 \mathrm{~kg})$. As the number of homes contributing nitrogen to ground water increases, the cumulative mass of nitrogen added to ground water rapidly increases. One-half of the total mass of nitrogen added during the 45-year period (1960-2005) was added during the last 12 years (1993-2005) (fig. 9).

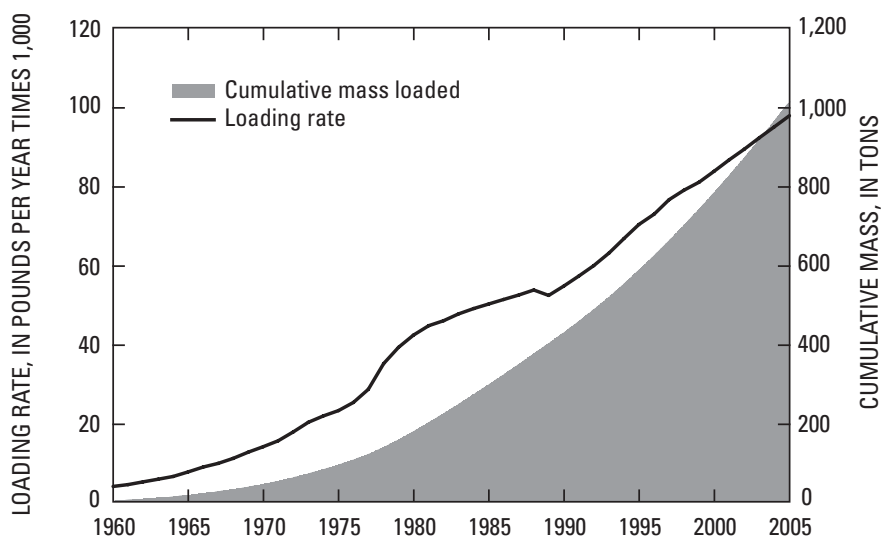

Figure 9. Annual and cumulative estimated nitrate loading from on-site wastewater systems in the La Pine, Oregon study area, 1960-2005. 


\section{Nitrate Fate and Transport Simulation Models}

Computer models were used to simulate the physical and chemical processes affecting the fate of nitrate in the shallow aquifer system near La Pine. The purpose of developing the models was to (1) test concepts of how hydrogeologic and geochemical processes affect the movement of nitrate through the ground-water system, and (2) provide tools that could be used to evaluate future water-quality conditions and alternative management options. This section describes the process of constructing and calibrating simulation models at two scales: (1) a transect model used to estimate model parameters and boundary conditions along a ground-water flow path where there is a detailed understanding of the flow system and geochemical evolution of ground-water, and (2) a studyarea model covering the area where there are water-quality management concerns.

This section includes: (1) discussion of the overall modeling approach used to construct and calibrate the transect and study-area models, (2) discussion of model parameters that must be specified for both models and how the values were estimated and modified during calibration, (3) discussion of hydrologic stresses specified for both models, (4) a detailed description of boundaries, discretization, and calibration of the transect model, and (5) a detailed description of boundaries, discretization, and calibration of the study-area model. Alternative management options were evaluated first by using the study-area model to simulate prescribed scenarios and then by coupling the study-area model with optimization methods. The coupled simulation and optimization model is referred to as the Nitrate Loading Management Model (NLMM).

\section{Modeling Approach}

The study-area model includes $247 \mathrm{mi}^{2}$ of southern Deschutes and northern Klamath Counties (fig. 10) where either existing or planned future development uses on-site wastewater systems. The study-area model was used to simulate the long-term effects of historical and future nitrate loading from on-site wastewater systems on ground-water quality in the study area.

The transect model is more detailed and includes $2.4 \mathrm{mi}^{2}$ of the shallow aquifer system near Burgess Road (fig. 10). The transect model was used during the calibration process to (1) test basic concepts of ground-water flow and nitrate fate and transport, and (2) refine estimates of model parameters through calibration in part of the study area where abundant geologic, hydrologic, and chemical data were available to constrain the model.
A regional ground-water flow model of the 4,500 $\mathrm{mi}^{2}$ upper Deschutes River basin was developed by Gannet and Lite, (2004) to address issues of water supply and groundwater/surface-water interaction. The model does not have the capability to simulate transport of nitrogen and the resolution (grid cell size) of the model grid is not adequate near La Pine to make this model an effective tool for addressing issues related to on-site wastewater systems. The regional model was used, however, to specify initial values of parameters and boundary conditions for the study area and transect models.

The first step in developing the transect and study-area models was to construct a ground-water flow model and simulate the velocity and direction of ground-water movement. This velocity distribution then was used in a solute-transport model to simulate the advection and dispersion of nitrate in the ground-water system. Steady-state flow conditions were assumed for the ground-water velocity distribution; that is, it was assumed that there were no changes in storage and the direction of ground-water flow and velocity did not significantly change during the simulation period. The steadystate flow models (transect and study area) were calibrated using observations (measurements) of hydraulic head, groundwater discharge rates to rivers, and chlorofluorocarbon (CFC) based time-of-travel estimates (Hinkle and others, 2007a). The accuracy of the transport model was evaluated by simulating nitrate loading during the 40-year period 1960-99 and comparing statistical distributions of observed and simulated ground-water nitrate concentrations.

Ground-water flow and nitrate transport were simulated using the programs MODFLOW-96 and MT3DMS. The U.S. Geological Survey's MODFLOW model (Harbaugh and McDonald, 1996) is a numerical simulation program capable of simulating hydraulic heads and ground-water flow within a three-dimensional system. The MT3DMS simulation program (Zheng and Wang, 1999) uses the velocity field computed by MODFLOW to simulate the movement of dissolved chemical species in ground water due to advection and dispersion. MT3DMS also is capable of simulating the effects of chemical reactions on the concentration of dissolved species.

The study-area and transect models developed for this study consist of a set of data input files that specify the boundary and initial conditions, the hydraulic and transport parameters, and the hydraulic and chemical sources and sinks specific to the study area. These input files provide the data required by the model programs (MODFLOW-96 and MT3DMS) to solve a complex set of partial differential equations that compute ground-water head and flux as well as solute concentration and flux in the subsurface. 


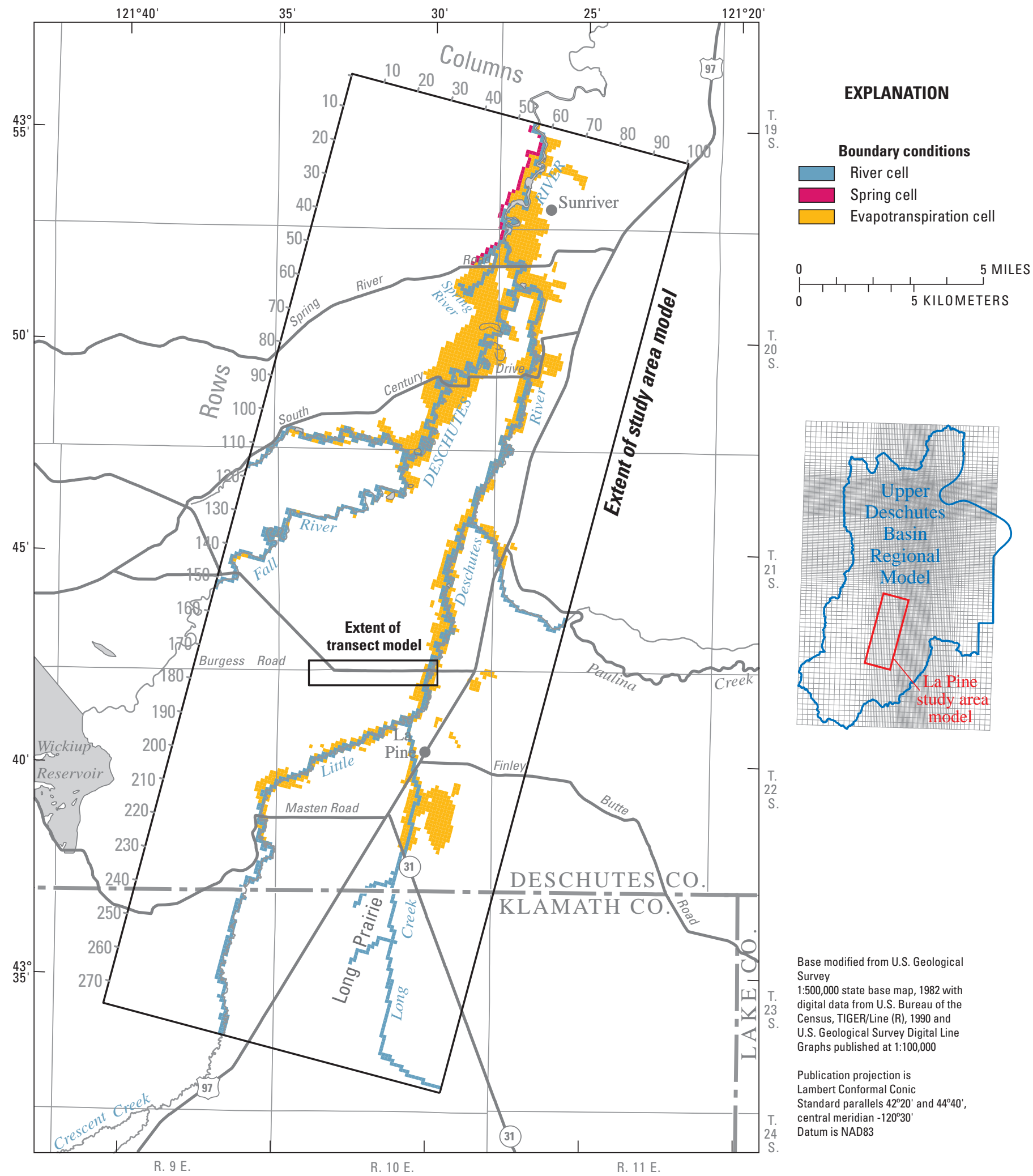

Figure 10. Spatial relations between the upper Deschutes Basin regional ground-water model, the La Pine study area model, and the transect model. 


\section{Model Parameters}

Several parameters must be specified for each cell in a model. These parameters, hydraulic conductivity, porosity, and dispersion coefficient, define the characteristics of the porous medium (geologic materials) that control the movement of ground water and the fate and transport of nitrate.

\section{Hydraulic Conductivity}

Initial values of hydraulic conductivity for the five major lithofacies in the hydrogeologic model were estimated using (1) results from 24 slug tests done for this study, (2) analysis of 221 well-yield tests reported by drillers, and (3) literature values. The three fluvial hydrofacies, clay-silt, sand, and gravel, were assigned values of 3,25 , and $57 \mathrm{ft} / \mathrm{d}$, respectively, based on mean values from the slug tests. The lacustrine clay-silt hydrofacies was assigned a value of $1 \mathrm{ft} / \mathrm{d}$. The initial value for the basalt hydrofacies was $800 \mathrm{ft} / \mathrm{d}$ based on values used by Gannett and Lite (2004) in the La Pine study area. The initial values of vertical hydraulic conductivity were derived by adopting the horizontal to vertical anisotropy ratio of 1,000 used in the regional model for the La Pine study area (Gannett and Lite, 2004). The resulting initial values of vertical hydraulic conductivity were $0.001,0.003,0.025,0.057$, and $0.8 \mathrm{ft} / \mathrm{d}$ for the lacustrine clay-silt, fluvial clay-silt, fluvial sand, fluvial gravel, and basalt hydrofacies, respectively. Initial values of horizontal and vertical hydraulic conductivity were assigned to each cell in the model on the basis of the hydrofacies represented in the cell.

\section{Porosity}

Effective porosity is defined as the amount of interconnected pore space and fracture openings available for the transmission of fluids, expressed as the ratio of the volume of interconnected pores and openings to the volume of rock (Lohman, 1972). Effective porosity generally is smaller than the total porosity of the porous medium, reflecting that some pore spaces may contain immobile water with zero groundwater seepage velocity (Zheng and Wang, 1999). However, as discussed in some detail by Zheng and Bennett (1995), this so-called effective porosity cannot be readily measured in the field due to the complexity of the pore structure. Rather, it generally must be interpreted as a lumped parameter and estimated during calibration by comparison of simulated and observed solute movement or ground-water travel time. An initial value of 0.30 was used for the effective porosity of all five hydrofacies.

\section{Dispersion}

The solute transport model includes the process of dispersion to account for factors such as diffusion, flow path tortuosity, and heterogeneities in the porous media that cause velocities to deviate from the average seepage velocity. The geostatistical method used to simulate the distribution of hydrofacies allowed the model to represent a great deal of the large scale heterogeneity in hydraulic properties. The scale of heterogeneities incorporated in the hydrogeologic model was, however, limited to the scale of the model grid (200 and $500 \mathrm{ft}$ laterally for the transect and study-area models, respectively, and $5 \mathrm{ft}$ vertically for both models). Because much of the heterogeneity occurs at scales that cannot be represented by a grid cell, the dispersion coefficient was used to represent the smaller (sub-grid cell) scale heterogeneity of the system. Additional factors, such as temporal variations in recharge rates and flow directions that affect solute transport often are incorporated into simulations as dispersion (Goode and Konikow, 1990).

Dispersion is represented by three dispersivity coefficients—one for longitudinal dispersivity, which represents dispersion along the primary flow axis, and two for transverse dispersivity values, which represent dispersion in the horizontal and vertical directions normal to the axis of flow. MT3DMS allows the user to specify the longitudinal dispersivity for each model layer and to set the transverse horizontal and transverse vertical dispersivity values as a fraction of the longitudinal dispersivity. The initial value for the longitudinal dispersivity was set to $50 \mathrm{ft}$ to represent subgrid cell heterogeneity. Typically, the horizontal transverse dispersivity is much smaller than the longitudinal dispersivity and the vertical transverse dispersivity is smaller still (Zheng and Bennett, 1995). Initial values for the transverse dispersivity were set to 5 and $0.5 \mathrm{ft}$ for horizontal and vertical, respectively. The final, calibrated longitudinal, transverse, and vertical dispersivity values were 60,6 , and $0.06 \mathrm{ft}$, respectively.

\section{Model Stresses}

Model stresses are the flows in and out of the groundwater system that are specified or simulated by the model. The stresses include recharge, discharge to springs and by evapotranspiration (ET), and exchange between streams and the ground-water system. Discharge by pumping wells is another stress, however it was not included in the model because seventy-five percent of domestic well pumping is returned as recharge from on-site wastewater systems. 
Recharge is the only specified stress in the models; other stresses are simulated by the model based on relations between head in the ground-water system and stream or springs elevation or the rooting depth of plants that discharge ground water by ET.

Specified flux and head-dependent flux boundary conditions were used to simulate movement of water between the ground-water system and streams, springs, and the atmosphere. Recharge by infiltration of precipitation was represented by specifying flux to the water table using the recharge $(\mathrm{RCH})$ package (Harbaugh and McDonald, 1996). Streams and rivers, springs, and evapotranspiration were represented using head-dependent flow boundary options in MODFLOW-96 (RIV, DRN, and EVT packages). The locations of cells designated as head-dependent flux boundaries are shown in figure 10 .

\section{Recharge}

The distribution of recharge by infiltration of precipitation and snowmelt was estimated for the upper Deschutes basin by Gannett and others (2001) using the Deep Percolation Model (DPM) of Bauer and Vaccaro (1987). The basin was modeled using a grid with cell dimensions of 6,000 ft per side. Gannett and Lite (2004) used estimated 1993-95 mean annual recharge to simulate steady-state conditions. The 1993-95 recharge distribution was used as the initial estimate of recharge to the study-area model; values for each cell were derived by overlaying the study-area model grid with the DPM model grid using a GIS (fig. 5). Neither recharge from on-site systems nor withdrawals by domestic wells were included in the model because, in the context of the overall water budget, these components are essentially equal and offsetting. Reductions in water level near pumping wells are not represented in the study-area model using this approach. Individual domestic wells may influence groundwater flow within localized areas (a few cells), but they would not have a significant effect on the direction and rate of ground-water flow at the scale the model is intended to be used.

\section{Rivers}

Ground-water discharge to and recharge from streams was simulated with the river (RIV) package of MODFLOW-96 (Harbaugh and McDonald, 1996). Data required by the RIV package include: mean stream stage, stream-channel elevation, and streambed conductance for each cell that contains a stream. All major streams in the study area were simulated using this method (fig. 10).

All stream-channel elevations were estimated using a 10-m digital elevation model (DEM). The mean stage was estimated to be $4 \mathrm{ft}$ above the streambed in the Deschutes
River, $2 \mathrm{ft}$ above the streambed in Paulina Creek and Little Deschutes River, and $1 \mathrm{ft}$ above the streambed in Long Creek. Streambed conductance (SC) is calculated using the equation:

$$
S C=\frac{K_{v} A}{b},
$$

where

$K_{v}$ is the vertical hydraulic conductivity of the streambed $\left(\mathrm{LT}^{1}\right)$,

Ais the area of the streambed within the cell $\left(\mathrm{L}^{2}\right)$, and $b$ is the thickness of the streambed (L).

Conductance values were variable depending on the hydrofacies of the cell and the area of the stream within the cell. The initial conductance values were calculated by assuming that the vertical hydraulic conductivity of streambed sediments was $1 / 100$ th of the horizontal hydraulic conductivity of the cell. Streambed thickness was set to $1 \mathrm{ft}$ throughout the model.

\section{Springs}

Ground-water discharge to springs was simulated with the drain (DRN) package of MODFLOW-96 (Harbaugh and McDonald, 1996). Data required by the DRN package include the spring elevation and conductance for each cell that contains a spring. This package was used to represent discharge from springs at the contact between the basinfill sediments and volcanic rocks on the west side of the Deschutes River between the confluence with Spring River and the northern boundary of the model (fig. 10). All spring elevations were estimated using a 10-m digital elevation model (DEM) data. The conductance parameter has the same dimensions $\left(\mathrm{L}^{2} \mathrm{~T}^{-1}\right)$ as the streambed conductance; however, the parameter cannot be easily related to measurable physical characteristics of the springs. Initial values of conductance ranged from 5,000 to $10,000 \mathrm{ft}^{2} / \mathrm{d}$ and were adjusted during calibration.

\section{Evapotranspiration}

Discharge from the water table by evapotranspiration (ET) was simulated using the EVT package of MODFLOW-96 (Harbaugh and McDonald, 1996). ET can occur where plants with roots extending to the water table (phreatophytes) use ground water for transpiration or where the water table is close enough to land surface to allow direct evaporation from bare soil. The EVT package uses the assumption of a linear relation between ET discharge and depth to the water table. Data required to define this relation are the potential ET rate $\left(\mathrm{LT}^{-1}\right)$, depth below land surface at which ET ceases (extinction 
depth), and land surface elevation (L). The potential ET rate was specified as $1.0 \mathrm{ft} / \mathrm{d}$, the extinction depth was $5 \mathrm{ft}$, and the land surface elevation was specified from DEM data. Only cells where the water table was estimated to be within $10 \mathrm{ft}$ of land surface were activated in the EVT package (fig. 10). The nitrate concentration in ground water used by plants in the ET process was specified as zero because the (1) part of modelsimulated ET that is due to plant transpiration (as opposed to evaporation from bare soil) could not be determined, and (2) nutrient uptake by phreatophytes is species dependent and not well constrained.

\section{Transect Model}

The transect model was developed for a part of the ground-water system near Burgess Road (fig. 10). This area was selected for detailed scale modeling because it was the site of intensive data collection and study of changes in ground-water age and chemistry along a ground-water flow path transect (Hinkle and others, 2007a). The 3.5-mi long transect model comprises 17 wells at 6 sites (2-4 wells per site) aligned with the predominant direction of groundwater flow (fig. 11). In addition to ground-water age and chemistry data, hydraulic head, lithologic data, and hydraulic conductivity data were available from the transect wells to construct and calibrate the transect model.

\section{Boundaries and Discretization}

The boundaries of the transect model (fig. 11) were selected to coincide with hydrogeologic boundaries of the local flow system. The western boundary of the model is a no-flow boundary defined by the ground-water divide that coincides with the surface-water drainage divide between the Deschutes and Little Deschutes Rivers. The north and south boundaries of the model are streamline boundaries that parallel the principal direction of ground-water flow from the drainage divide to the Little Deschutes River. The Little Deschutes River, a discharge area, was simulated as a head-dependent flux boundary. The initial conceptual model of the system included a deep regional component of upward ground-water flow across the lower model boundary. The concept for the lower boundary was evaluated by applying a specified flux across the lower model boundary based on data from the regional ground-water flow model by Gannett and Lite (2004). The upward flux estimates from the regional model did not allow a good simulated match to observed conditions (head and flux) when hydraulic conductivity and recharge values were within reasonable ranges based on independent data. Little or no upward flow from a deep regional source is needed to simulate the observed distribution of head and estimated ground-water flux to the Little Deschutes River. Upward vertical gradients were measured in well pairs in the area and geochemical evidence indicates that ground-water discharge to areas near the rivers may have a deep regional component (Hinkle and others, 2007a). Seepage estimates and simulations using the transect model, however, indicate that the magnitude of regional discharge must be small compared to local recharge to the shallow alluvial aquifer. The lower boundary of the transect model was specified as a no-flow boundary.

The numerical methods used by MODFLOW and MT3DMS to solve the equations for ground-water flow and solute transport require that the ground-water system be divided into discrete rectangular volumes, called cells. The rows, columns, and layers of cells that make up the threedimensional array are collectively referred to as the model grid. The center of each cell defines a point at which the hydraulic head and solute concentration is simulated. The simulated head and concentration values are taken to represent the average values within the cell.

The longest dimension of the model grid was aligned to the principal direction of ground-water flow from west to east. The grid consists of 18 rows, 92 columns and 15 layers of cells, with each cell having dimensions of $200 \mathrm{ft}$ in the row and column directions and $5 \mathrm{ft}$ in the vertical direction. The three-dimensional transect model was $3.5 \mathrm{mi}$ in the east-west (column) direction, 0.7 mi wide in the north-south (row) direction (normal to the principal direction of flow), and $75 \mathrm{ft}$ thick in the vertical (layer) direction (fig. 11).

A three-dimensional hydrofacies model of the fluvial and lacustrine sediments within the transect flow model was constructed using the methods previously described for constructing the hydrofacies model for the study-area model. A sectional view through the model along row 8 is shown in figure $11 \mathrm{C}$ and illustrates the heterogeneity of the fluvial sediments. Transition probability geostatistical methods were used with the same model parameters (mean lengths, transition probabilities, and proportions) as were used for the study-area hydrofacies model, however the transect hydrofacies model was discretized into cells with the same dimensions as the transect simulation model.

\section{Calibration and Sensitivity}

The MODFLOW model was first calibrated to steadystate flow conditions using head data from the June 2000 synoptic well measurement. Data were available from 26 wells within the transect model area (fig. 11); 17 wells were piezometers installed as part of the Burgess Road transect study and 9 were existing domestic water-supply wells.

Observations (either measurements or estimates) of ground-water discharge to streams were available to constrain model calibration; however, flux between the Little Deschutes River and the shallow ground-water system was difficult to characterize because of uncertainty in the seepage measurements. The apparent gains and losses for the 13-mi 


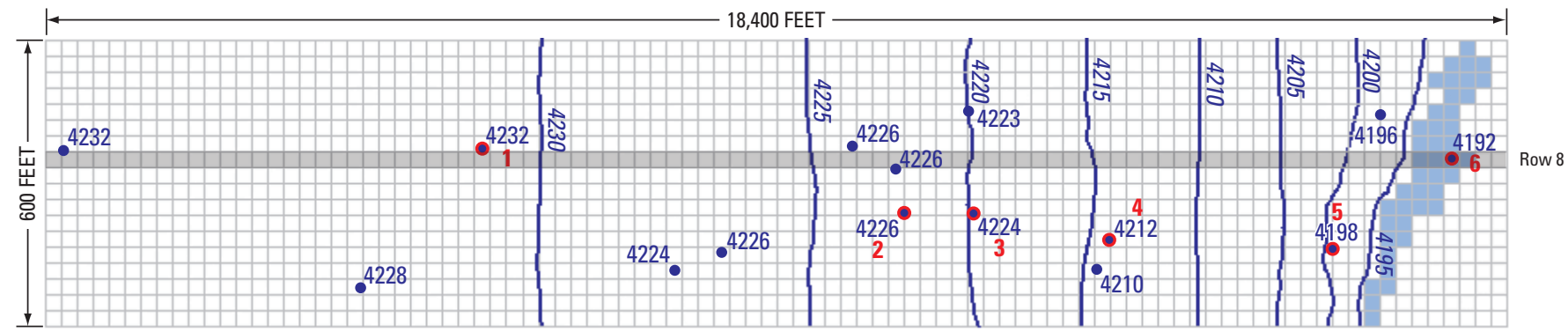

A. PLAN VIEW OF TRANSECT MODEL GRID
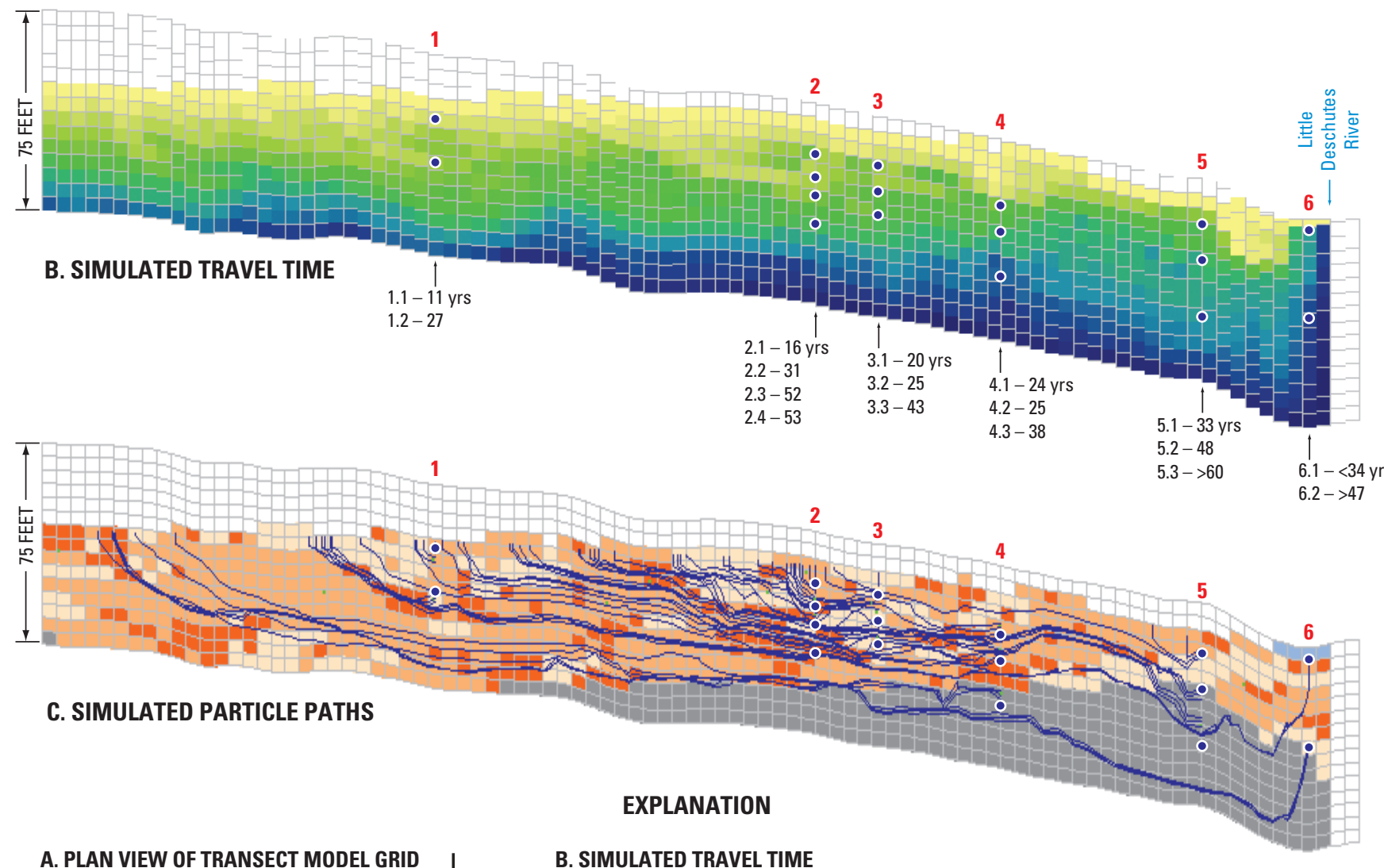

\section{A. PLAN VIEW OF TRANSECT MODEL GRID}

\begin{tabular}{|c|c|}
\hline$\square$ & Cell \\
\hline$\square$ & Cell simulated as stream \\
\hline 4230 & $\begin{array}{l}\text { Contour of simulated water-table } \\
\text { elevation }\end{array}$ \\
\hline 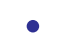 & Well location \\
\hline - & Transect well location \\
\hline 4228 & $\begin{array}{l}\text { Measured water-table elevation, } \\
\text { in feet, June } 2000\end{array}$ \\
\hline 2 & Transect well No. \\
\hline
\end{tabular}

\section{B. SIMULATED TRAVEL TIME}

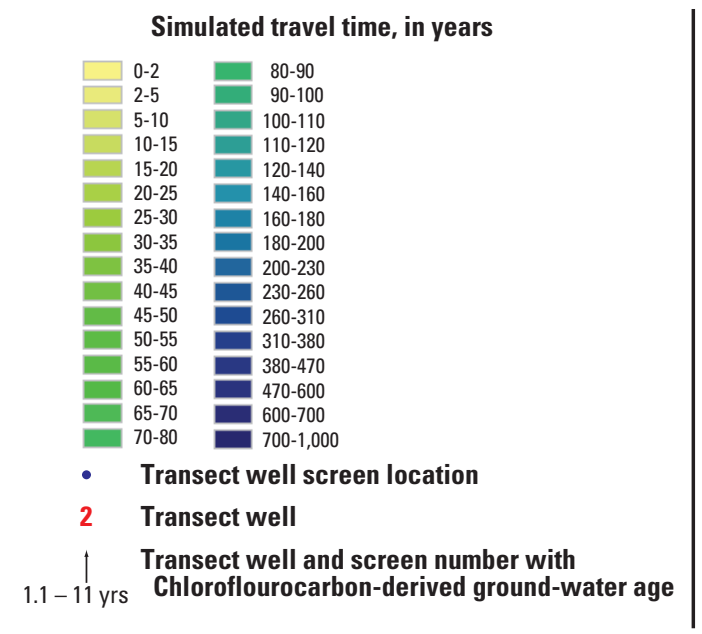

\section{SIMULATED PARTICLE PATHS}

Hydrofacies

\begin{tabular}{|l|l}
\hline & Unsaturated \\
& Fluvial clay-silt \\
& Fluvial sand \\
& Fluvial gravel \\
& Lacustrine clay-silt \\
& Volcanics: basalt, andesite \\
& Cell simulated as stream \\
& Simulated particle path \\
\hline & Transect well screen location \\
\hline $2 \quad$ Transect well No.
\end{tabular}

Figure 11. Plan and section views of the transect model showing simulated water-levels, ground-water travel time, and particle paths in the La Pine, Oregon, study area. (Location of the transect model is shown in figure 10.) 
reach downstream of the gaging station (14063000) ranged from a $2.6 \mathrm{ft}^{3} / \mathrm{s}$ gain in October 1995 to a $1.6 \mathrm{ft}^{3} / \mathrm{s}$ loss in October 2000 (table 4). These 1995 and 2000 estimates were less than the estimated error of measurement $\left( \pm 3.9 \mathrm{ft}^{3} / \mathrm{s}\right.$ and $\pm 6 \mathrm{ft}^{3} / \mathrm{s}$, respectively). A third seepage measurement in March 2000 indicated a $12 \mathrm{ft}^{3} / \mathrm{s}$ loss in this reach, but this loss was based on measurements at relatively high flow conditions (about $300 \mathrm{ft}^{3} / \mathrm{s}$ ) with a larger associated error. For calibration purposes, October low-flow data were interpreted to indicate that net seepage to or from this reach (1) is small relative to flow, and (2) probably varies in direction as well as magnitude depending on annual or seasonal head relations between shallow ground water and the stream. A key component of the conceptual model of the shallow flow system is that, on annual or longer time scales, there is net discharge to the Little Deschutes River. On this basis, a range of discharge to the stream for the transect model area was computed using the October 1995 seepage $\left(2.6 \mathrm{ft}^{3} / \mathrm{s}\right)$ as the minimum and the sum of seepage and estimated error of measurement $\left(6.5 \mathrm{ft}^{3} / \mathrm{s}\right)$ as the probable maximum for the range. Dividing seepage and estimated error of measurement by the length of the reach (13 mi) yielded a range of 0.20 to $0.50 \mathrm{ft}^{3} / \mathrm{s} / \mathrm{mi}$ and the resulting range of expected mean annual ground-water discharge to the $1.3 \mathrm{mi}$ reach of the Little Deschutes in the model area was 0.3 to $0.7 \mathrm{ft}^{3} / \mathrm{s}$ (rounded).

During the calibration process, parameters such as horizontal and vertical hydraulic conductivity, recharge, and streambed conductance were adjusted, using a trial-anderror procedure, to obtain the best fit between observed and simulated head and stream flux values. The transect model also was used to evaluate estimates of upward vertical flux across the lower boundary from the regional flow model.

Horizontal hydraulic conductivity $\left(\mathrm{K}_{\mathrm{h}}\right)$ and vertical hydraulic conductivity $\left(\mathrm{K}_{\mathrm{v}}\right)$ values were assigned to each cell according to the hydrofacies represented in the cell. The probable range of $\mathrm{K}_{\mathrm{h}}$ based on well-yield data and slug tests and the calibrated $\mathrm{K}_{\mathrm{h}}$ value that yielded the best model fit are listed in table 5 . The probable range of vertical hydraulic conductivity for each hydrofacies was computed assuming that the probable range of the horizontal to vertical anisotropy ratio was 10 to 10,000 for the hydrofacies in the model area. The vertical anisotrophy ratio in the final model was equal to 100 for all hydrofacies.

Streambed conductance was estimated on the basis of the assumption that the vertical hydraulic conductivity in streambed sediments was $1 / 100$ th of the horizontal conductivity of the hydrofacies in the model cell. A series of simulations were made to test model sensitivity to streambed conductance values. Conductance values were modified by adjusting the ratio of streambed $\mathrm{K}_{\mathrm{v}}$ to aquifer $\mathrm{K}_{\mathrm{h}}$, over a range of 0.001 to 0.1 , but the transect model was relatively insensitive to this parameter.

Recharge estimates for the transect model area range from 1.5 to $2.1 \mathrm{in} / \mathrm{yr}$. The lower end of the range was estimated by using a water balance model for the upper Deschutes Basin (Gannett and others, 2001); the upper end of the range was computed by using CFC-derived age data from the Burgess Road transect study (Hinkle and others, 2007a). The best model fit was obtained with a slightly higher recharge rate of $2.3 \mathrm{in} / \mathrm{yr}$.

Hydraulic heads and discharge to the stream simulated by the transect model were most sensitive to recharge and horizontal hydraulic conductivity of the fluvial clay-silt and lacustrine clay-silt hydrofacies. The fluvial sediments are relatively thinner than the lower permeability lacustrine sediments near the river and this tends to reduce the composite transmissivity of the aquifer system. The location, thickness, and extent of clay-silt hydrofacies within the fluvial sediments are relatively unimportant factors controlling ground-water flow because the contrast in hydraulic conductivity between the gravel, sand, and clay-silt hydrofacies is small compared to the contrast between the fluvial and lacustrine hydrofacies. Fitting simulated to observed heads was accomplished by adjusting values of hydraulic conductivity for each hydrofacies, until a best model fit was obtained by trial and error.

Table 5. Values of horizontal and vertical hydraulic conductivity for hydrofacies based on field data and model calibration in the La Pine, Oregon, study area.

\begin{tabular}{|c|c|c|c|c|}
\hline \multirow{2}{*}{ Hydrofacies } & \multicolumn{2}{|c|}{$\begin{array}{l}\text { Horizontal hydraulic } \\
\text { conductivity, } \mathrm{K}_{\mathrm{h}} \\
\text { (feet per day) }\end{array}$} & \multicolumn{2}{|c|}{$\begin{array}{l}\text { Vertical hydraulic } \\
\text { conductivity, } \mathrm{K}_{\mathrm{v}} \\
\text { (feet per day) }\end{array}$} \\
\hline & $\begin{array}{c}\text { Probable } \\
\text { range }\end{array}$ & $\begin{array}{l}\text { Calibrated } \\
\text { value }\end{array}$ & $\begin{array}{c}\text { Probable } \\
\text { range }\end{array}$ & $\begin{array}{c}\text { Calibrated } \\
\text { value }\end{array}$ \\
\hline Fluvial clay-silt & $1-20$ & 5 & $0.001-2$ & 0.05 \\
\hline Fluvial sand & $10-100$ & 40 & $0.01-10$ & .40 \\
\hline Fluvial gravel & $75-150$ & 75 & $0.075-15$ & .75 \\
\hline Lacustrine clay-silt & $0.1-10$ & 10 & $0.0001-1$ & .10 \\
\hline Basalt & $100-2,500$ & 150 & $0.01-250$ & 1.5 \\
\hline
\end{tabular}


The calibrated parameter values (table 5) and boundary conditions produced a good model fit to head and flux observations. Contours of simulated water-table elevation compare well with observed water-table elevations at 15 wells (fig. 11A) where measured heads represent the water table. The root mean square error (RMSE) of the head residuals at the 26 well locations was $2.7 \mathrm{ft}$. Model fit was slightly better (RMSE $=2.3 \mathrm{ft}$ ) at the 17 transect wells, where head measurements were more accurate because (1) measuring point elevations at the wells were surveyed, whereas elevations at other wells were estimated from topographic maps, and (2) short (2-ft) screens in the transect wells provided better observations of head within the 5-ft thick model cells, whereas screens in other wells were longer and spanned multiple model layers. The simulated heads have a slight bias that results in a steeper slope of the water table toward the Little Deschutes River. The bias probably could be reduced with further calibration if the configuration of the lacustrine-fluvial sediment boundary were modified; however, there was no basis (using existing geologic data) to modify the hydrofacies model and the bias was small and did not significantly affect average simulated flow velocities.

\section{Simulated Travel Time and Comparison with Ground-Water Age}

Estimates of ground-water age were used to further constrain the calibration of the transect model. Ground-water age estimates at 17 wells in 6 locations along the Burgess

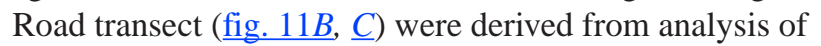
CFCs (Hinkle and others, 2007a). A particle tracking program, MODPATH, (Pollock, 1994) was used to determine the simulated travel time of ground-water from recharge locations at the water table to the well screens where CFC samples were collected from the 17 transect wells. The simulated travel times were compared with the CFC-derived age estimates to evaluate the accuracy of the simulated ground-water velocity distribution.

MODPATH uses the cell-to-cell fluxes simulated by MODFLOW to compute velocity field and path lines of individual "particles" of water that may be started at any location and tracked either forward to their discharge location or backward to their recharge location. The only additional parameter required by MODPATH (that is not required by MODFLOW) is effective porosity. Effective porosity was assumed to be 0.3 for each hydrofacies within the model. For this analysis, 1,000 particles were placed in each of the 17 model cells that contained the screen of a transect well. The particles were tracked backward to their recharge locations at the water table (fig. 11C). Because of limitations of the tracking program, particles could not be placed at the exact location of the well screens within each cell, but were placed at the center of the cell and distributed along a vertical line $5-\mathrm{ft}$ long (the thickness of the cell).
Simulated ground-water travel time distribution is shown in figure 11B for row 8 of the transect model. The simulated distribution shows a pattern similar to the distribution of CFC-derived ages from the 17 transect wells. Generally, ground-water travel times are less than 10 years within the upper 5-15 ft of the saturated zone and travel times within $30-50 \mathrm{ft}$ of the water table are less than 50 years. Simulated ground-water travel times are notably greater than CFC ages at well 4.3, the deepest at site 4 . Travel times are difficult to predict at this site because the screen for well 4.3 is near the upper surface of the fine-grained, lacustrine clay-silt hydrofacies. The model predicts that "older" water will occur at this location because slow-moving water from the lacustrine sediments re-enters the fluvial sediments as it follows flow paths toward the discharge areas along the river. At the discharge end of the flow path, near the Little Deschutes River, older water occurs at shallower depths as it moves upward to discharge to the river. The relation between ground-water age and depth depicted in the section (fig. 11B) is analogous to the relation between dissolved oxygen concentration and depth described by Hinkle and others (2007a).

\section{Study-Area Model}

Initial estimates for many parameters in the studyarea model were derived from calibration and testing of the transect model. The study-area model was first calibrated for simulation of ground-water flow using observations of head and discharge to streams. As with the transect model calibration, simulated heads were compared with waterlevel data from the synoptic measurement of 228 wells in June 2000 (fig. 5). Simulated ground-water discharge to streams was compared with estimates of discharge from gain-loss measurements (fig. 7, table 4). The measured head and discharge data were assumed to represent the long-term average (steady-state) conditions in the ground-water system. Once the study-area flow model was calibrated, the simulated ground-water flow directions and velocity were used to simulate the transport and fate of nitrate. Transport of nitrate from on-site wastewater systems was simulated for 1960-99 using the estimated annual nitrate loading rates. The transport model was evaluated by comparing the statistical distribution of simulated nitrate concentration with statistical distributions of measured nitrate concentrations from analyses available mostly from domestic wells.

The transport model calibration period was divided into 401 -year stress periods. During each 1-year period, the nitrate loading rate in each model cell was specified. The specified rate was dependent on the number and type (domestic, commercial, etc.) of on-site wastewater systems present. 


\section{Boundaries and Discretization}

The model grid for the La Pine study-area model includes an area of $247 \mathrm{mi}^{2}$ (fig. 10). The grid is elongated along a northeast-southwest trend that coincides with the orientation of the structural basin, major drainages, and the depositional strike and dip of the basin-fill sediments. The axes of the grid also are orthogonal to the principal directions of ground-water flow. There are 276 rows, 100 columns, and 24 layers in the model grid. The lateral dimensions of each cell are $500 \mathrm{ft}$ in both the $\mathrm{x}$ and $\mathrm{y}$ directions. The upper 23 layers of the model were each $5 \mathrm{ft}$ thick and the bottom layer was $100 \mathrm{ft}$ thick. The coordinates of the lower left corner of the grid are 4,609,651 $\mathrm{ft}$ east and 696,295 ft north (Oregon State Plane north) and the grid is rotated 15 degrees clockwise.

The fluvial sand and gravel aquifers that supply most drinking water to wells in the area lie within the upper $100 \mathrm{ft}$ of sediments. Between depths of 10 to $100 \mathrm{ft}$, depending on location in the study area, there is a transition from the coarser fluvial sediments to predominately fine-grained lacustrine sediments (fig. 2 , pl. 1). As previously described, the fluvial deposits are heterogeneous and include fine-grained facies of clay, silt, and silty-sand. Similarly, coarse facies occur within the lacustrine deposits, although they tend to be isolated lenses. The simulation model was constructed to include the upper $120 \mathrm{ft}$ of sediments so that the model would include the entire thickness of fluvial sediments. Each of the 24 model layers had a thickness of $5 \mathrm{ft}$ throughout the grid. The grid for the study-area flow and transport model was defined to exactly match the dimensions of the grid used to prepare the three-dimensional hydrogeologic model described earlier in this report.

Long-term well hydrographs (fig. 6) indicate that groundwater flow in the shallow part of the system is in a state of dynamic equilibrium. Seasonal and interannual variations in water level and ground-water storage are due to climatic variation, but no long term trend is evident in mean water levels. The June 2000 synoptic water level measurements (fig. 5) were assumed to represent the mean annual head distribution for the system and were used as the head observations used as calibration targets for the steady-state study-area and transect flow models.

The lateral and bottom boundaries of the model were selected to include the most densely developed part of the study area and the shallow alluvial deposits that form the primary aquifers. The lateral and bottom boundaries of the model do not coincide with specific hydrologic or geologic boundaries such as geologic contacts or ground-water flow divides. The potential magnitude of flow across the lateral and lower model boundaries was evaluated by model testing and sensitivity analysis with both the transect and study area models. The upper boundary of the model is the water table, which is the top of the saturated part of the ground-water flow system.
The study area transport model used steady-state flow velocities to simulate nitrate fate and transport. Nitrate loading from on-site wastewater systems was simulated for 1960-99 in forty 1 -year periods. The loading for each period was computed using building records and other information as previously described (fig. 9). Nitrate loading was specified in the transport model using the mass-loading option in the source/sink mixing package of MT3DMS (Zheng and Wang, 1999). The mass loading rate to each cell, in kilograms per day, was specified at the water table for each year of the simulation. Initial nitrate concentrations were assumed to be zero at the beginning of the simulation in 1960 .

Based on the conceptual model for denitrification (Hinkle and others, 2007a), the transition zone from oxic to suboxic conditions was represented as a sharp boundary that does not vary significantly with time. Although the redox boundary would be expected to migrate as solid-phase electron donors are consumed by dissolved oxygen and nitrate reduction, the effectiveness of this approach for characterizing current zones of nitrate stability and instability is supported by analysis of data collected by ODEQ (Hinkle and others, 2007a). Hinkle presents field data from the area showing that 95 percent of samples with nitrate concentrations greater than $1.0 \mathrm{mg} \mathrm{N} / \mathrm{L}$ taken from wells with known construction were screened at least partly within the mapped (fig. 8) oxic zone.

The position of the boundary within the models was specified by subtracting the thickness of the oxic part of the aquifer (fig. 8) from the water-table elevation (fig. 5) to obtain the elevation of the oxic-suboxic boundary. The boundary was assumed to be in each vertical stack of cells at the top of the first fully suboxic cell. The boundary was implemented in MT3DMS by using the ICBUND array to specify a constant concentration of zero in suboxic cells (Zheng and Wang, 1999).

\section{Calibration and Sensitivity}

\section{Calibration of Ground-Water Flow}

Ground-water fluxes across the lateral and lower boundaries of the study-area model initially were specified on the basis of the regional ground-water flow model developed by Gannett and Lite (2004). The uppermost layer of the regional model was $100 \mathrm{ft}$ thick and represented both alluvial deposits and basalts. The regional model simulates large subsurface flow through the permeable basalts that underlie the northern part of the study area (fig. 2). Most of the flow remains within the basalts of the regional flow system and discharges to the Deschutes River and tributaries north of the study area (Gannett and others, 2001). Some of the flow through the basalts, however, discharges to springs that contribute to the Deschutes, Fall, and Spring Rivers in the northwestern part of the study-area model. These springs 
generally are located where high permeability basalts abut lower permeability sediments, forcing ground water to discharge at land surface (Gannett and others, 2001).

Where alluvial deposits occur at the lower and lateral boundaries of the study area model, the flux simulated between the regional and study-area models was generally small. This is consistent with results of testing the transect model that indicated upward leakage across the lower boundary was not required to match the observed head distribution and ground-water discharge to streams when using reasonable values for recharge and hydraulic conductivity. This result indicates that upward leakage is small compared to local recharge from infiltration of precipitation.

When the simulated flux across the lower and lateral model boundary was included in the simulation, the study-area model had numerical stability problems in the northern part of the model area, which is underlain by basalt. The stability problems were characterized by large fluctuations in simulated heads that were probably caused by (1) a large flux through a relatively thin section (120 ft) of the basalts, and (2) adjacent model cells with large contrasts in hydraulic conductivity (high hydraulic conductivity basalts in immediate contact with low conductivity alluvial deposits).

To test the sensitivity of model results to specified flux at the lateral and lower model boundaries, a simulation was made specifying zero flux at these boundaries. Simulated heads and flux to streams were determined to be insensitive to the regional model boundary flux where basalts were not present. Few data points were available to constrain the heads in the basalt uplands and, therefore, even though simulated heads were affected in the basalts, it is difficult to assess how well or poorly they match actual heads. The simulated discharge to springs along the Fall, Spring, and Deschutes Rivers in the northern part of the model area also were affected, but the model showed much better stability. Nearly all potential concerns related to nitrate from on-site wastewater systems are focused on parts of the study area underlain by alluvial deposits. Simulation of flux through the basalts and of discharge from large springs at the basalt-alluvium contact was of less importance and did not inhibit the ability of the model to simulate conditions in the alluvial deposits; therefore, to attain better model stability in the part of the model representing basalts, the zero-flux boundary condition was used for the lower and lateral boundaries of the study-area model.

The contours defining the simulated steady-state potentiometric head surface retain the general features of the surface defined by contours of measured heads from the 2000 synoptic measurement (fig. 12). Both simulated and observed flow directions (inferred from contours) support other data (vertical head gradient and gain-loss measurements) that indicate, on an annual basis, ground water discharges to nearly all stream reaches in the study area.
The model simulated the general direction of groundwater flow (northeast) accurately in the area between the Deschutes and Little Deschutes Rivers in southeast T20S/ R10E and northeast T21S/R10E; however, the model did not simulate as steep a horizontal hydraulic gradient as indicated by the contours of observed heads shown in figure 12 . The location of this area between the two rivers and at the focal point of ground-water flow for a large part of the study area, make it difficult to characterize the mean annual head distribution. Seasonal differences in the stage of the Deschutes and Little Deschutes Rivers can cause relatively large seasonal variations (5-10 ft) in ground-water levels. The period of high river stage in spring coincides with the peak recharge period for the shallow aquifer. These conditions lead to larger horizontal head gradients, particularly in this area, when the water levels used to construct the contours in figure 12 were measured (June 2000). The simulated recharge and river stage conditions represent mean annual conditions, as do the simulated heads, whereas the contours shown in figure 12 may represent a seasonal extreme. The transient influence of the rivers makes it difficult to accurately simulate ground-water flow velocity and direction in this area; however, the model simulates the mean annual direction of flow and velocity reasonably well. On-site wastewater systems are not used in this area so it is not likely that the model would be used to predict concentration in this area. Long Creek was represented in the model using head-dependent flux boundaries for ET and streams to account for discharge in the topographically low area; the effects of ground-water discharge are reflected in the V-shaped simulated and observed contours (fig. 12).

The mean absolute error for the 170 head observations was $7.0 \mathrm{ft}$, or about 5 percent of the range of observed heads. The difference between simulated and observed head ranged from -20 to $45 \mathrm{ft}$ (fig. 13). The largest differences generally were at wells with long open intervals, in which the measured head represents a composite head for a large thickness of the system. The simulated heads used for comparison in such cases were for the model layer closest to the center of the open interval of the well. The differences between simulated and observed head generally were less than $10 \mathrm{ft}$ in the central part of the study area, between the Deschutes and Little Deschutes Rivers. Errors in the simulated heads will result in errors in the ground-water velocity field that in turn will affect simulation of nitrate transport. These errors would affect simulated concentrations at small scales, but would not affect the average simulated nitrate concentration over large areas.

Recharge to the water table, which was 98 percent of total recharge, was the only specified component of the simulated water budget. The mean annual recharge rate of $58 \mathrm{ft}^{3} / \mathrm{s}$ was equivalent to an average of $3.2 \mathrm{in} / \mathrm{yr}$ within the study area model. The other components of recharge and discharge were simulated using head-dependent boundary conditions, as previously described. The simulated recharge from streams 


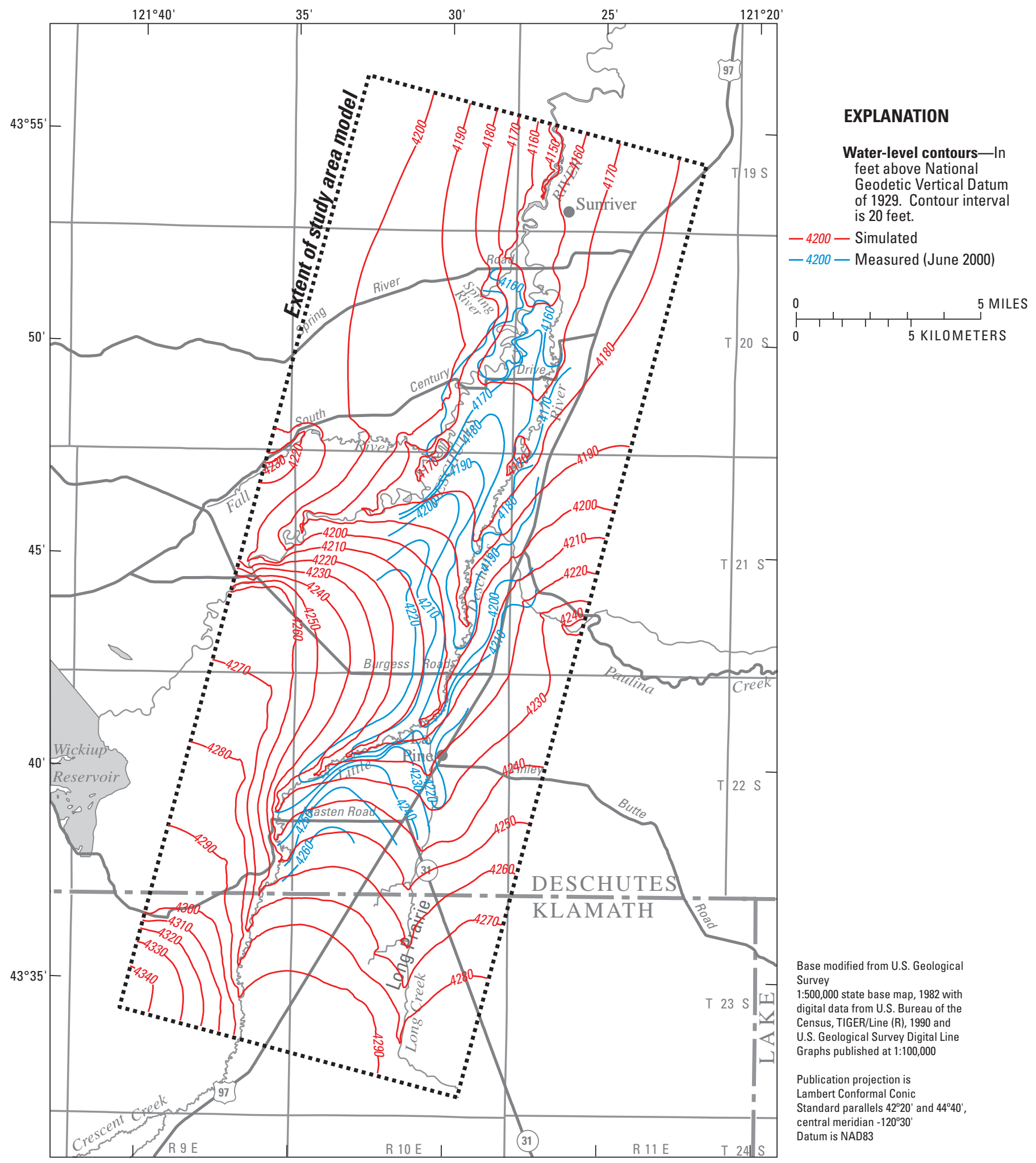

Figure 12. Contours of simulated and observed heads (June 2000) for the La Pine, Oregon, study area. 


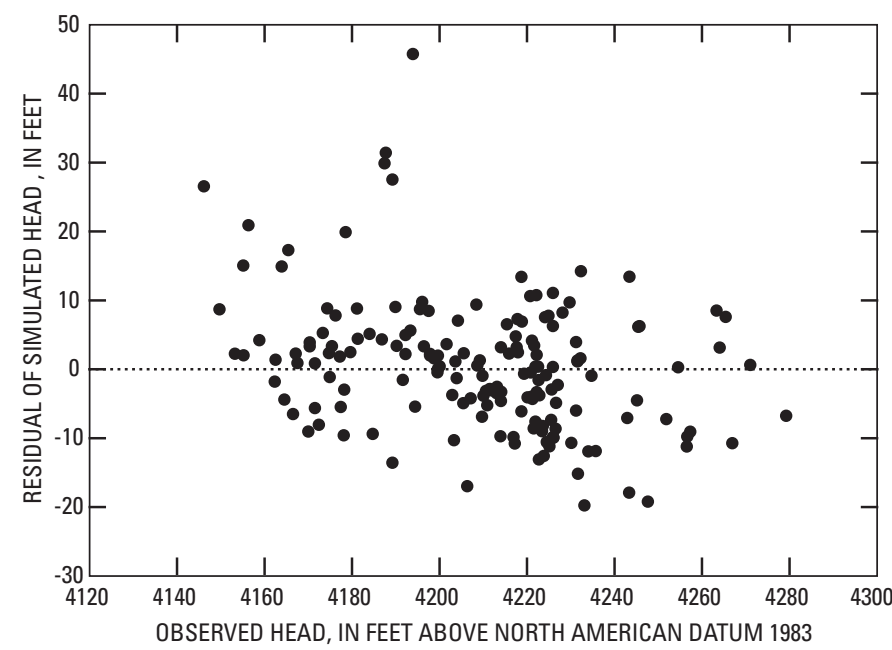

Figure 13. Simulated head residuals and observed heads (June 2000) from the La Pine, Oregon, study area.

was small $\left(1.3 \mathrm{ft}^{3} / \mathrm{s}\right)$ and was from a few isolated stream reaches where simulated heads were less than the specified stage of the stream. Because the simulated system is assumed to be at steady state (no long-term change in storage), total discharge is equal to recharge. Ground-water discharge to streams accounts for 67 percent $\left(39.5 \mathrm{ft}^{3} / \mathrm{s}\right)$ of total discharge. Simulated discharge to the Little Deschutes River is $15 \mathrm{ft}^{3} / \mathrm{s}$ which is within the range of 7 to $20 \mathrm{ft}^{3} / \mathrm{s}$ expected on the basis of measured discharge (table 4). Simulated groundwater discharge to the Deschutes River was $12 \mathrm{ft}^{3} / \mathrm{s}$ and was consistent with measurement data for reaches upstream of river mile 199.7. Downstream of river mile 199.7 on the Deschutes River and on the Fall River, most ground-water discharge emanates from the large springs where basaltic rocks are in contact with the lower permeability alluvial sediments. Recharge by subsurface inflow to the basaltic rocks that feed these springs was not simulated in the study-area model. The simulated discharge to ET of $16 \mathrm{ft}^{3} / \mathrm{s}$ fell within the estimated range of $10-20 \mathrm{ft}^{3} / \mathrm{s}$ and was distributed within the floodplain, where shallow water-table conditions persist through the dry months (fig. 10).

\section{Comparison of Simulated and Measured Nitrate Concentrations}

The study-area transport model simulates nitrate concentrations in ground water and in ground-water discharge to the near-stream environment. Simulated concentrations are averages for the 500-ft wide by 500-ft long by 5 -ft thick model cells. With cells covering nearly 6 acres and minimum lot sizes of 0.5 acre, each cell can contain as many as about
10 homes. Nitrate data collected for this study from closely spaced sampling locations near the Burgess Road transect model (Hinkle and others, 2007a) indicate that even in mature, high-density residential areas, nitrate plumes have not coalesced to a great degree, and concentrations are highly variable at the scale of an individual model cell. Because of the high variability of nitrate concentrations in a cell, concentrations at individual wells cannot be simulated with the study-area model. The inability to delineate the edges of, and concentrations within, individual solute plumes is a limitation of transport models at the watershed scale. This limitation does not affect this study because the information from the model is intended to help understand and predict water quality conditions at scales larger than individual plumes or wells; however, it does limit the degree that measured nitrate concentration data from wells can be used for direct comparison with simulated concentrations.

To assess of the ability of the study-area model to represent the primary processes that affect nitrate movement in the ground-water system, the statistical distribution of simulated nitrate concentrations was compared with distributions for two sets of measured nitrate concentrations from wells. The first measured dataset was from a synoptic sampling of 192 wells in June 2000 by ODEQ (Hinkle and others, 2007a). Only data from the 109 wells where ground water was oxic (dissolved oxygen concentration was greater than $0.5 \mathrm{mg} / \mathrm{L}$ ) were used in the comparison because denitrification has been shown to be an important process where ground water is suboxic (Hinkle and others, 2007a). The second observed dataset was collected under a program administered by Oregon Department of Human Services Health Division (DHS), which requires that water from domestic wells is tested whenever a property is sold. Nitrate analyses from 1,572 such tests were available for homes in the La Pine area (Rob Keller, ODEQ, written commun., August 2006). The DHS data were collected from 1989 to 2004. Dissolved oxygen concentrations are not analyzed as part of the DHS program so it was not possible to discriminate wells that pump from the suboxic part of the system.

The simulated nitrate concentrations used for comparison were from the end of the simulation period (1999) and were taken from 1,398 cells randomly selected from locations where active on-site wastewater systems existed. Only cells that contained oxic ground water were selected (because suboxic cells would have simulated concentrations of zero by default) and more than one cell could be selected from more than one layer in the same row/column. The statistical distributions of measured nitrate concentrations and the simulated concentrations are similar (fig. 14). The maximum simulated nitrate concentration was $29 \mathrm{mg}$ N/L, with a mean of $2.0 \mathrm{mg} \mathrm{N} / \mathrm{L}$, and a median of $0.8 \mathrm{mg} \mathrm{N} / \mathrm{L}$, and 10 percent 


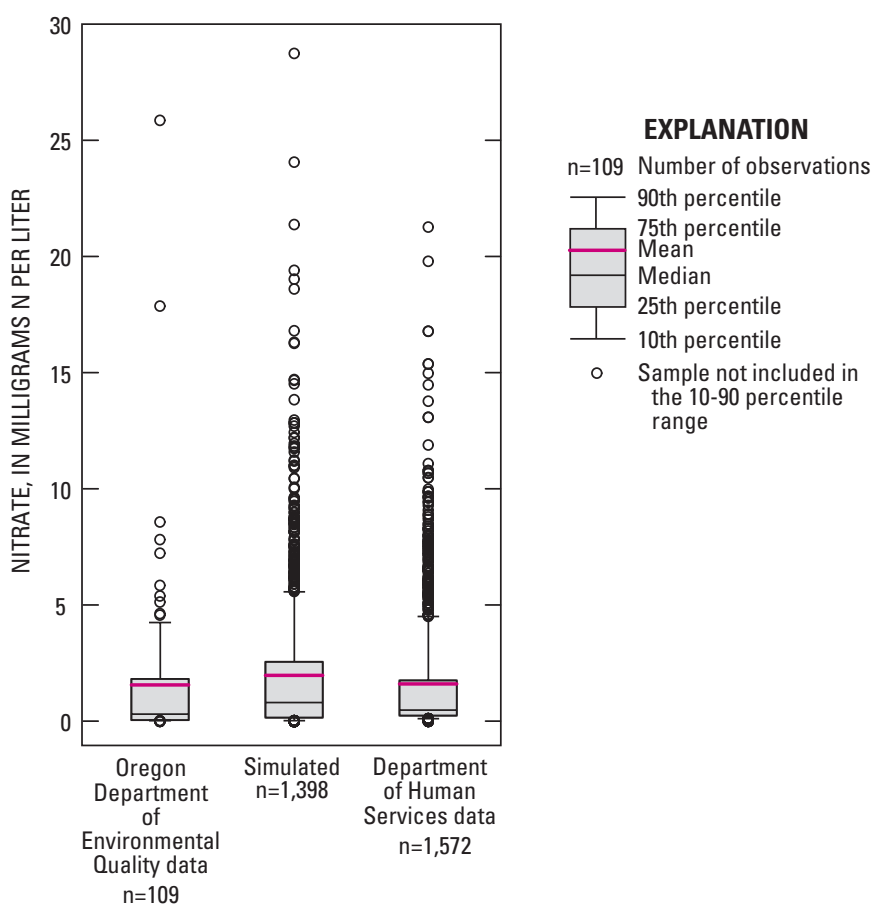

Figure 14. Measured and simulated nitrate concentrations in the La Pine, Oregon, study area, 1999.

of concentrations greater than $6 \mathrm{mg} \mathrm{N} / \mathrm{L}$. The maximum of the ODEQ June 2000 synoptic nitrate concentration data was $26 \mathrm{mg} \mathrm{N} / \mathrm{L}$, with a mean of $1.6 \mathrm{mg} \mathrm{N} / \mathrm{L}$, and a median of $0.3 \mathrm{mg} \mathrm{N} / \mathrm{L}$, and 10 percent of concentrations greater than $4 \mathrm{mg} \mathrm{N} / \mathrm{L}$. The maximum of the DHS real estate nitrate concentration data was $22 \mathrm{mg} \mathrm{N} / \mathrm{L}$, with a mean of $1.6 \mathrm{mg} \mathrm{N} / \mathrm{L}$, and a median of $0.5 \mathrm{mg} \mathrm{N} / \mathrm{L}$, and 10 percent of concentrations greater than $4.5 \mathrm{mg} \mathrm{N} / \mathrm{L}$. The primary difference in the three nitrate concentration distributions was the slightly greater proportion of high values in the simulated concentration distribution. This difference is likely due to simulated values being sampled from the entire thickness of the oxic part of the system, including cells near the water table where nitrate loading occurs and concentrations are greatest. Samples from the measured datasets were collected from wells where the screened intervals typically were below the water table and would be less likely to include water with high nitrate concentrations. Good agreement between the summary statistics of the measured and simulated nitrate concentrations (mean, median, $90^{\text {th }}$ percentile, and maximum) indicates that the simulated mass of nitrate in the ground-water system at the end of the 1960-99 period, is similar to the mass indicated by available sample data. This agreement increases confidence that the primary processes affecting the fate and transport of nitrate in the ground-water system are represented in the simulation model. Even though the model does not simulate concentrations at individual wells, it is a useful tool for assessing the effects of on-site systems on average groundwater nitrate concentrations at the scale required for evaluation of management alternatives for protecting ground-water quality.

The spatial distribution of simulated nitrate concentration at the water table in 1999 is shown in figure 15 and closely mirrors the locations of on-site wastewater systems (fig. 1). The effect of ground-water movement on nitrate concentration is evident where areas of high concentration are elongated parallel to the primary directions of ground-water flow, such as immediately south of Burgess Road. The effect of denitrification on the simulated distribution is evident where concentrations sharply decrease along easterly ground-water flow paths that terminate at the Little Deschutes River, such as in central T21S R10E (fig. 15). The sharp concentration gradient is coincident with an area where the oxic part of the system decreases in thickness (compare fig. 8). This decrease, along with the downward component of advective transport, forces a large fraction of the nitrate in the system to be transported into the suboxic zone and lost to denitrification.

At the end of the simulation period (1999), the rate of nitrate (as N) loading to the ground-water system was $82,000 \mathrm{lb} / \mathrm{yr}(37,000 \mathrm{~kg} / \mathrm{yr})$. The simulated rate of denitrification in the suboxic part of the system was $31,000 \mathrm{lb} /$ $\mathrm{yr}(13,900 \mathrm{~kg} / \mathrm{yr})$ and the simulated discharge of nitrate to the near-stream environment was 8,000 lb/yr (3,650 kg/yr). The remaining 43,000 lb/yr $(19,400 \mathrm{~kg} / \mathrm{yr})$ was added to storage in the shallow ground-water system. Nitrate added to storage increased the mean concentration in the ground-water system from essentially zero in 1960 to a mean of $2 \mathrm{mg} \mathrm{N} / \mathrm{L}$ in 1999.

\section{Management Scenario Simulations}

Simulation models often are developed with the goal of using them for predicting future effects of management strategies. The study-area model was initially used in what is referred to as a trial-and-error prediction mode. In this mode, future scenarios are designed in which the nitrate loading input to the model is varied according to a hypothetical set of management strategies that could be imposed. The locations and rates of loading over time are specified as input to the simulation model and the model predicts the resulting distribution of nitrate concentrations in the aquifer and the discharge of nitrate to the streams. The scenario results then are compared to assess whether management strategies succeeded in meeting water-quality goals. This is referred to as a trial-and-error procedure because often many simulations must be made to find management strategies that meet water quality goals. The results of the scenario simulations are presented here for later comparison to results of the simulation-optimization approach. 


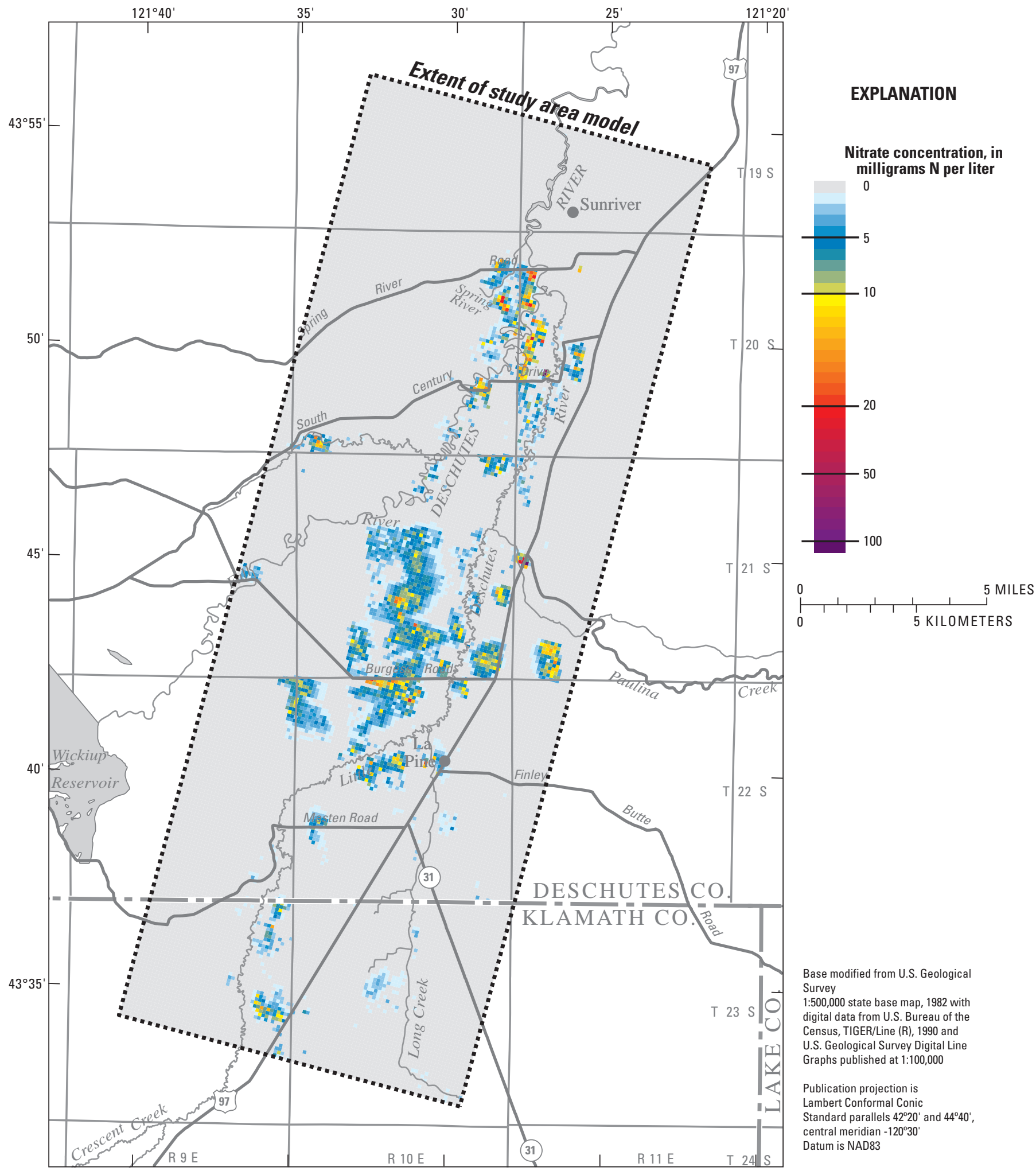

Figure 15. Simulated nitrate concentrations near the water table in the La Pine, Oregon, study area, 1999. 
The calibrated simulation model was used to predict the effects of eight decentralized wastewater management scenarios on ground-water and surface-water quality. Scenario number 1 was defined as the "base" scenario which would be used to evaluate the effects of a "no action" management strategy and serve as a benchmark for evaluating the benefits of other management alternatives. Under the base scenario, homes built on approximately 4,100 undeveloped lots remaining in 2000 used conventional on-site wastewater systems. Conventional systems were assumed to produce the same effluent concentration (46 mg N/L) and loading as used during the 1960-1999 model calibration simulations. The remaining seven scenarios were defined by Deschutes County using two primary management options to reduce nitrate loading: (1) a transferable development credit (TDC) program to reduce the number of on-site wastewater systems in the area, and (2) advanced treatment on-site wastewater systems. Deschutes County has modified the TDC program since the scenarios were defined; however the goal of the original TDC program was to reduce the number of on-site septic systems in the area by shifting, or transferring, development to a receiving area served by a community sewer and water system.

Advanced treatment on-site wastewater systems capable of removing nitrogen were extensively field-tested as part of the La Pine NDP (Barbara Rich, ODEQ, written commun., 2003). Based on data from the field testing program, three levels of nitrogen reduction performance were evaluated using the simulation model. Three reduction levels, expressed as a percentage of the nitrate concentration in effluent reaching the water table from conventional systems (46 mg N/L), were used: 57, 78, and 96 percent. These reductions would be equivalent to effluent nitrate concentrations at the water table of 20,10, and $2 \mathrm{mg} \mathrm{N} / \mathrm{L}$, respectively. Four additional scenarios were defined where advanced treatment systems were combined with a TDC program in which development of 1,500 lots was moved to a receiving area served by centralized sewer.

Additional assumptions for the scenarios included:

- Development would continue at the 1990-99 rates of 250 homes per year until full build-out (in 2019);

- All new homes would use advanced treatment on-site wastewater systems; lots where new homes were built each year were randomly determined;

- Locations of existing homes where conventional on-site wastewater systems were upgraded to advanced treatment systems were randomly selected in each year;

- Upgrades were done at a rate of 94 per year (based on historic rate of system repair permits issued by county) until all on-site wastewater systems had been upgraded (2056); and

- For scenarios involving TDCs, 1,500 lots were randomly selected from a pool of 2,600 candidates provided by Deschutes County.
Descriptions of the scenarios and the resulting nitrate loading rates are summarized in table 6.

Each scenario was simulated for 140 years beginning in 2000. The historical nitrate loading rates (1960-99) are compared with estimated future loading rates (2000-2139) for each scenario in figure 16.

Under the base scenario (number 1, table 6), all available lots (as of 2000) were projected to be developed by 2019, and figure 16 shows that estimated nitrogen loading continued to increase until that time, after which loading remained constant at a rate of $147,000 \mathrm{lb} / \mathrm{yr}$. Simulation of the base scenario showed that nitrate concentrations continued to increase long after the maximum loading rate was reached in 2019. This is because the amount of nitrate entering the groundwater system will exceed the amount leaving the system until equilibrium is reached. Equilibrium occurs when loading is balanced by the sum of the rates of denitrification and discharge of nitrate to streams. The simulation model suggests that it could take more than 140 years to reach equilibrium for scenario 1. At equilibrium, 78 percent of nitrogen entering the system $(114,000 \mathrm{lb} / \mathrm{yr})$ will be transported to the suboxic part of the aquifer and removed by denitrification. The remaining 22 percent $(33,000 \mathrm{lb} / \mathrm{yr})$ will be transported into the nearstream areas adjacent to the Little Deschutes and Deschutes Rivers. This should be considered an upper bound on the amount of nitrate reaching the rivers because the current study area model cannot account for processes (denitrification, plant uptake, microbial uptake) that may remove nitrate from ground water before it discharges to the rivers.

The simulated nitrate concentrations for scenario 1 exceeded $10 \mathrm{mg}$ N/L over large areas prior to equilibrium, however at equilibrium, the nitrate concentration near the water table averaged more than $10 \mathrm{mg}$ N/L over areas totaling about 9,400 acres (table 7, fig. 17).

The results of the other seven scenarios showed improved water-quality conditions for each level of increased nitrate loading reduction. Simulations indicate significant improvements in overall ground-water quality for all performance levels tested if all new homes use advanced treatment on-site wastewater systems and all existing homes replace conventional on-site wastewater systems with advanced treatment on-site wastewater systems. For the $20 \mathrm{mg} \mathrm{N} / \mathrm{L}$ nitrate performance level without a TDC program (scenario 3 ) the area where nitrate concentrations exceed the $10 \mathrm{mg} \mathrm{N} / \mathrm{L}$ drinking-water standard is reduced by 80 percent to about 1,900 acres (table 7 , fig. 18) at equilibrium. A further reduction in effluent nitrate concentration, to $10 \mathrm{mg}$ $\mathrm{N} / \mathrm{L}$, (scenarios 5 and 6) reduced the area where simulated equilibrium nitrate concentrations exceed $10 \mathrm{mg} \mathrm{N} / \mathrm{L}$ to less than 700 acres. The maximum reduction, to $2 \mathrm{mg} \mathrm{N} / \mathrm{L}$, (scenarios 7 and 8) resulted in only a few small areas with concentrations greater than $10 \mathrm{mg} \mathrm{N} / \mathrm{L}$, and those areas were related to nonresidential loading ( $\mathrm{RV}$ parks) not reduced under the scenarios. 
Table 6. Summary of eight on-site wastewater management scenarios tested with the study-area model in the La Pine, Oregon, study area.

[TDC lots: assumes 1,500 lots eremoved from pool of candidate lots. Locations were randomly selected from 2,600 possible lots. Retrofitting: assumes all on-site systems serving homes built prior to 2000 are retrofitted with advanced systems with performance equal to systems installed in new homes. Retrofits are made at a rate of 94 per year until completed in 2057.

Abbreviations: TDC, transferable development credit; lb/yr, pound per year; $\mathrm{mg} \mathrm{N} / \mathrm{L}$, milligram nitrogen per liter]

\begin{tabular}{cccccccc}
\hline Scenario & $\begin{array}{c}\text { Effluent } \\
\text { recharge } \\
\text { concentration } \\
\text { (mg N/L) }\end{array}$ & $\begin{array}{c}\text { Percent } \\
\text { reduction } \\
\text { from standard } \\
\text { systems }\end{array}$ & TDC lots & Retrofitting & $\begin{array}{c}\text { Peak } \\
\text { loading } \\
\text { (Ib/yr) }\end{array}$ & $\begin{array}{c}\text { Peak } \\
\text { loading } \\
\text { year }\end{array}$ & $\begin{array}{c}\text { Final } \\
\text { loading } \\
\text { (Ib/yr) }\end{array}$ \\
\hline 1 & 46 & 0 & No & No & 147,000 & 2019 & 147,000 \\
2 & 46 & 0 & Yes & No & 125,000 & 2013 & 125,000 \\
3 & 20 & 57 & No & Yes & 93,000 & 2019 & 65,300 \\
4 & 20 & 57 & Yes & Yes & 88,100 & 2013 & 55,900 \\
5 & 10 & 78 & No & Yes & 81,200 & 2000 & 34,200 \\
6 & 10 & 78 & Yes & Yes & 81,200 & 2000 & 29,500 \\
7 & 2 & 96 & No & Yes & 80,400 & 2000 & 9,200 \\
8 & 2 & 96 & Yes & Yes & 80,400 & 2000 & 8,300 \\
\hline
\end{tabular}

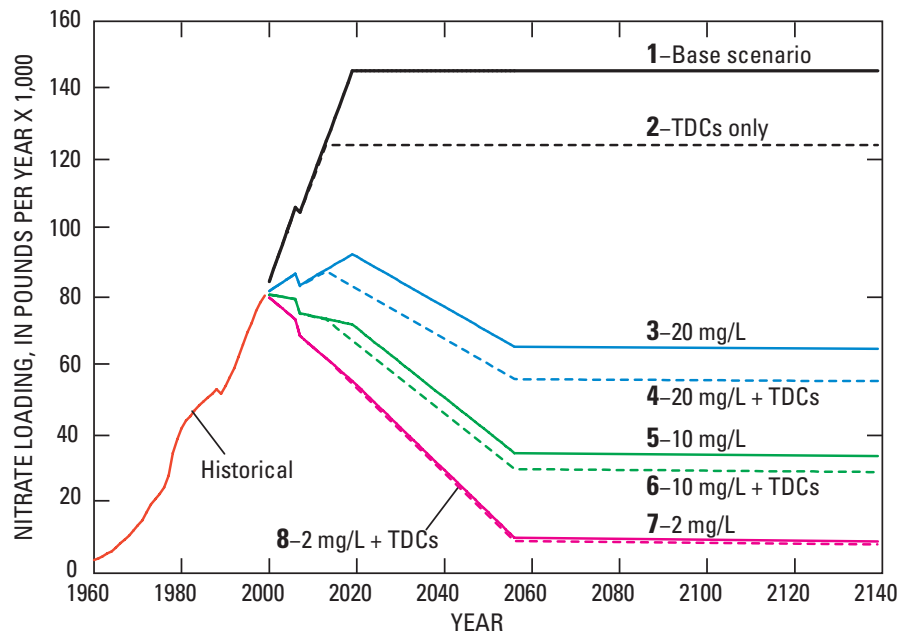

Figure 16. Historical nitrate loading from on-site wastewater systems and eight nitrate loading scenarios tested with the study-area model.

See table 6 for scenario descriptions. (mg/L, milligram per liter; TDC, transferable development credit.) 
Table 7. Summary of model simulation results for eight on-site wastewater management scenarios tested with the study-area model in the La Pine, Oregon, study area.

[Acres are based on simulated nitrate concentrations in the uppermost active (saturated) model cells. E quilibrium acreages are based on simulated nitrate concentrations at end of simulation (2139). Peak acreages are based on simulated nitrate concentrations in the year when the highest concentrations occur for each scenario. Abbreviations: TDC, transferable development credit; mg N/L, milligram nitrogen per liter; lb/yr, pound per year; mg/L, milligram per liter;

Symbol: -, no data]

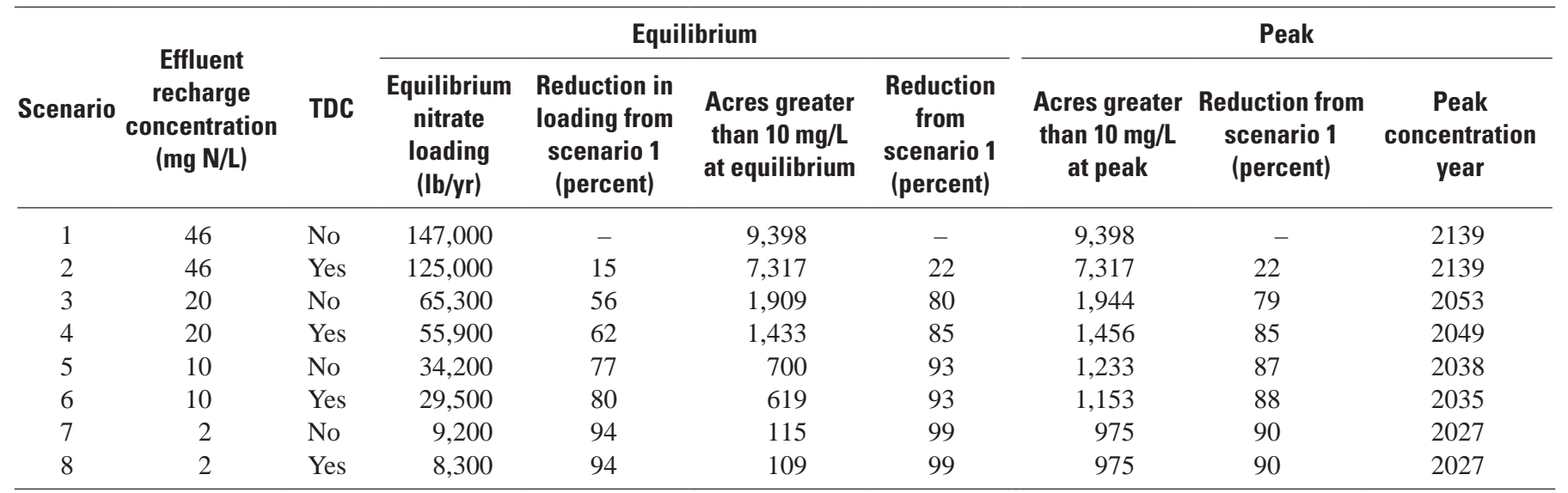

Each scenario in which conventional systems were replaced with advanced treatment systems indicated that ground-water nitrate concentrations would peak between 2027 and 2053 (about 25-50 years after loading reduction begins) and then decrease to their equilibrium levels. Less time is required to reach the peak and subsequent equilibrium concentrations for scenarios with greater reductions in loading (table 7).

The TDC program, as defined for these scenarios, reduced the number of homes that would use on-site wastewater systems by shifting or transferring development of new homes to a receiving area with centralized wastewater treatment. Using conventional on-site systems, the 1,500 homes selected for the TDC program in the scenarios would contribute about $21,000 \mathrm{lb}$ of nitrogen annually, with each home adding $14 \mathrm{lb} / \mathrm{yr}$ to the aquifer. This equals nearly 14 percent of the total base scenario loading of 147,000 lb/yr. For other scenarios, in which advanced treatment on-site wastewater systems are used, the effect of a program like this is diminished. For example, if advanced treatment systems reduce effluent concentration from 46 to $10 \mathrm{mg} \mathrm{N} / \mathrm{L}$, the annual loading per home is reduced from 14 to $3 \mathrm{lb} / \mathrm{yr}$. Under this scenario, removing 1,500 homes only reduces total loading by $4,500 \mathrm{lb} / \mathrm{yr}$ ( 3 percent). The relative effectiveness of the TDC program in reducing loading at various levels of assumed advanced on-site system performance is shown in figure 16. Development transfer programs (like the TDC program) might be most effectively applied in high-sensitivity areas, where advanced treatment on-site wastewater systems cannot meet loading reduction goals.
Results of trial-and-error simulations show that the capacity to receive on-site wastewater system effluent and maintain satisfactory water-quality conditions is variable within the study area. The capacity of any area to receive on-site wastewater system effluent is related to many factors, including the density of homes, presence of upgradient residential development, ground-water recharge rate, groundwater flow velocity, and thickness of the oxic part of the aquifer.

Each scenario tested with the simulation model was limited to management strategies that were applied uniformly in the study area. Typically, this is how simulation models must be used because as the size and complexity of the waterquality management problem increases, the decision makers' ability to design scenarios with management strategies that reflect variability in the loading capacity of individual areas is diminished. Uniform management strategies, such as requiring all on-site wastewater systems to meet the same nitrate reduction standards, may be more costly than variable management strategies that account for the variability in the nitrate loading capacity of the ground-water system. Uniform strategies that are stringent enough to protect water quality in some areas may be more than is needed to protect water quality in other areas. The simulation model represents the hydrogeologic and chemical processes that cause this variability, and by adding optimization capability to the model, the nitrate loading capacity of the ground-water system can be determined for individual management areas. 


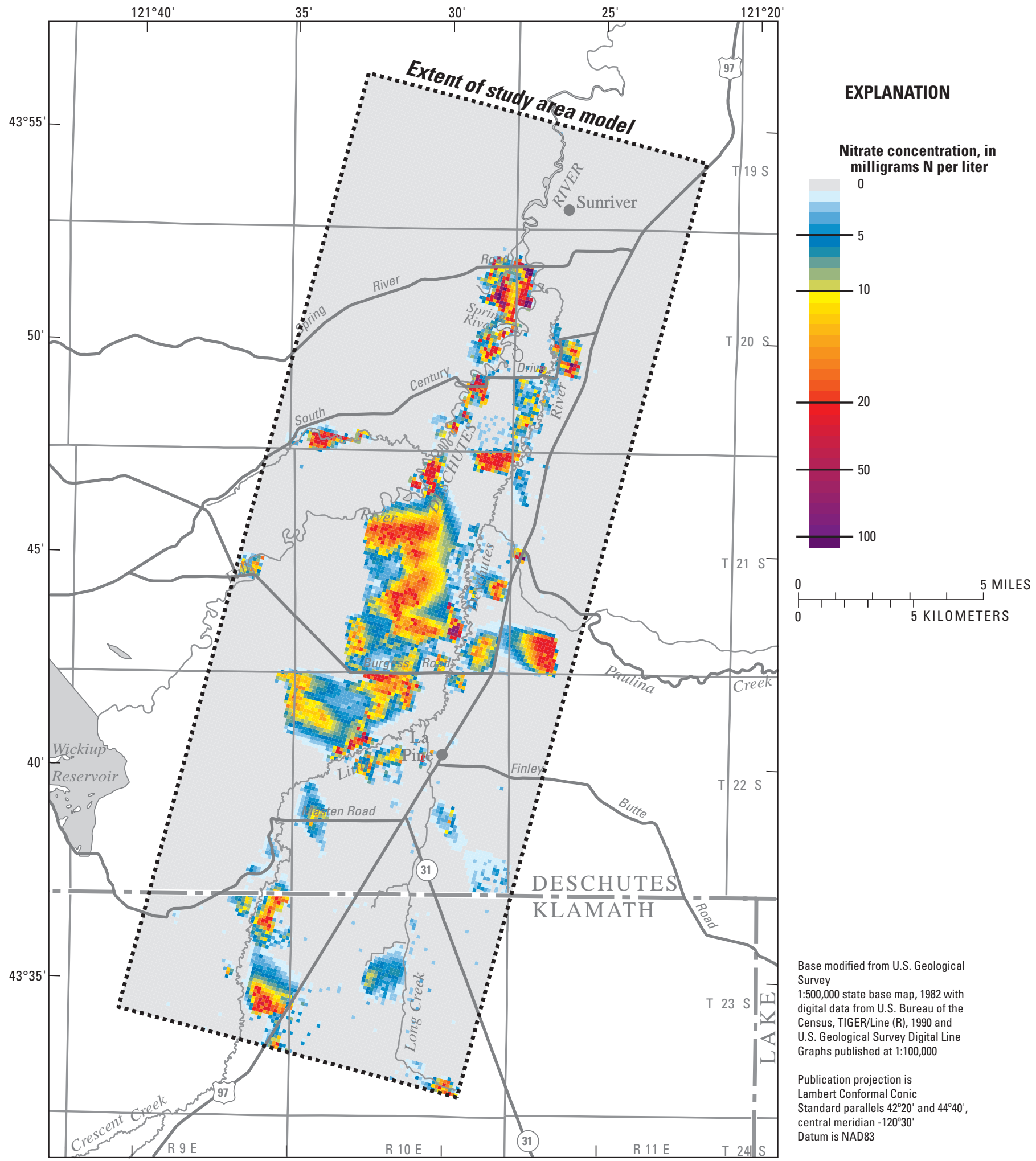

Figure 17. Simulated equilibrium ground-water nitrate concentrations near the water table for the base scenario (scenario 1, $\underline{\text { table } 6)}$ in the La Pine, Oregon, study area. (Colors indicate maximum nitrate concentration in vertical dimension.) 


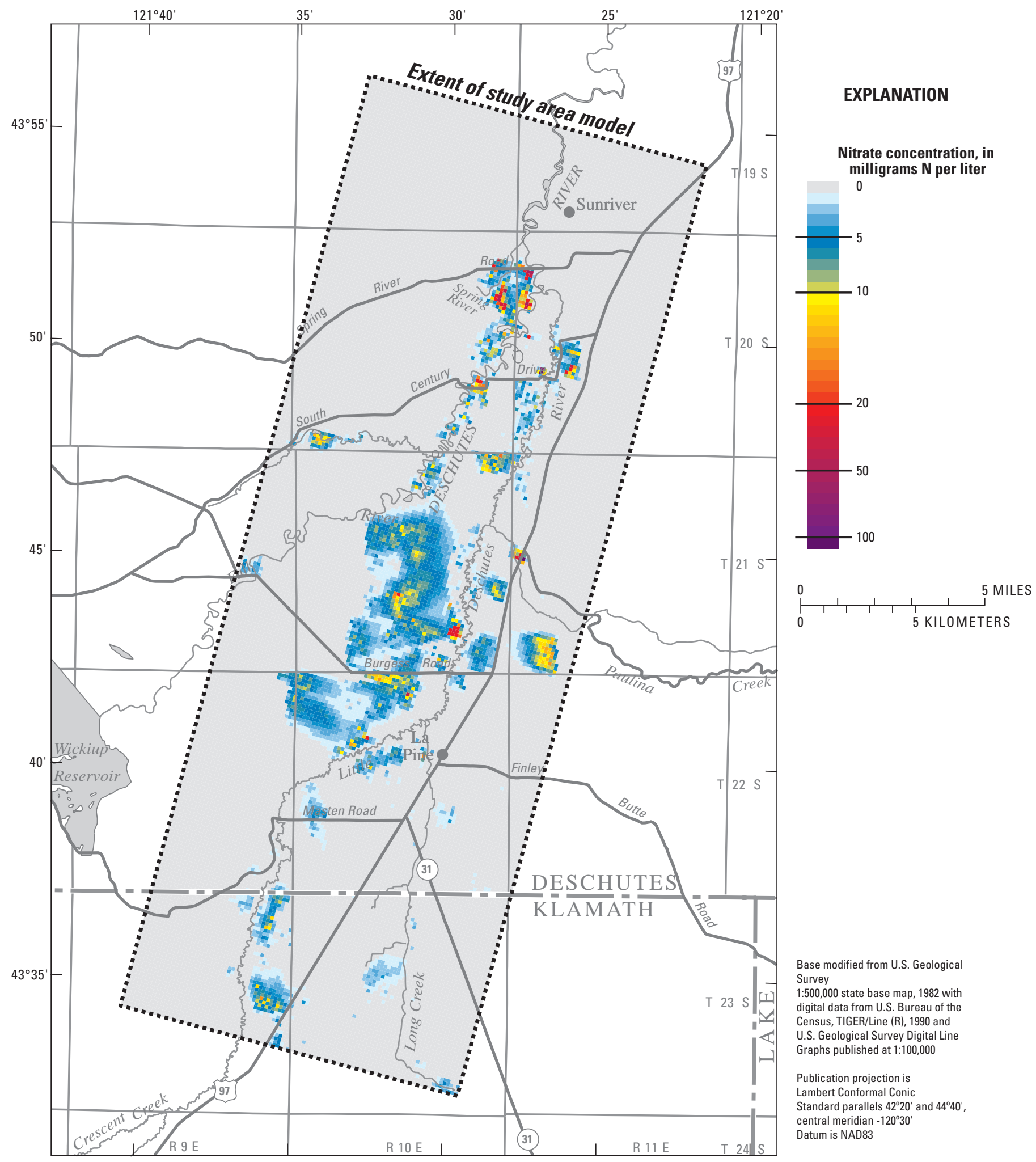

Figure 18. Simulated equilibrium ground-water nitrate concentrations near the water table for 20 milligrams $N$ per liter advanced treatment on-site wastewater systems (scenario 3, table 6) in the La Pine, Oregon, study area. (Colors indicate maximum nitrate concentration in vertical dimension.) 


\section{Nitrate Loading Management Model}

The study-area simulation model was linked to optimization methods to produce the Nitrate Loading Management Model (NLMM). This section includes a description of how the management model was formulated, how it is solved, and how it can be used to evaluate alternative strategies for managing nitrate loading to the shallow groundwater system.

\section{Formulation of Nitrate Loading Management Model}

To use optimization methods, management goals must be formulated into a mathematical structure. The structure of an optimization problem has three components that must be defined: decision variables, an objective function, and constraints.

One inherent value of the optimization approach is that its use requires decision makers and stakeholders to quantify planning goals and objectives as well as environmental and other constraints. The La Pine NLMM was formulated through a close collaboration with Deschutes County planners and resource managers. The management objective of the NLMM, to minimize the reduction from base scenario nitrate loading from on-site wastewater systems, reflects the goals of: (1) allowing as many platted lots as possible to be developed under current development goals and policies, and (2) minimizing the required reduction in nitrate loading from existing on-site systems. Because costs are associated with reducing loading either by not allowing development or using advanced treatment on-site wastewater systems, the management objective can be simply stated as "minimize the cost" of meeting water-quality goals. The water-quality goals are constraints on the management model and have direct and quantifiable effects on the solution (or cost) and their values often reflect regulatory requirements or economic and community values. If regulatory standards apply, the process of setting water-quality constraints is straightforward. However, if less well defined economic or community values are to be the basis for water quality constraints, then a tradeoff analysis is a common process for finding the balance (or evaluating the relations) between costs and economic, aesthetic, health, environmental, and other benefits. The management model can assist in this process by quantifying the relationships between constraints and management objectives.

The NLMM was formulated mathematically to minimize the reduction in nitrate loading (or cost of reduction) from base scenario loading, subject to constraints on minimum reductions in ground-water nitrate concentrations (relative to base scenario), minimum reductions in ground-water discharge nitrate loading to streams (relative to base scenario), and minimum and maximum loading reductions for existing and future homes in each management area.

The decision variables in the La Pine NLMM were the reduction in nitrate loading (relative to base scenario nitrate loading rates) that would be needed to maintain or achieve desired water-quality conditions. See table 6 for a description of the base scenario. (Nitrate loading rates were specified using metric units [kilograms per day] in the NLMM and these units are used in the following description of the model for consistency.) To define decision variables, the study area was divided into 97 management areas. The basic unit for the management areas was a 160-acre area (quarter-section) based on the Public Land Survey System. With the goal of making the base scenario loading in each management area approximately equal, as many as four quarter-sections (640 acres) were combined to form management areas in areas with lower lot density. The average number of lots in each management area was approximately 100 (fig. 19). The model had 194 decision variables, NR ${ }_{\mathrm{i}, \mathrm{j}}$, because two decision variables were defined for each management area: loading reduction (kilograms per day, $\mathrm{kg} / \mathrm{d}$ ) for existing homes and loading reduction for future homes. About 350 homes and lots were not included in the NLMM because they were in low density areas. These homes and lots represented only $7 \mathrm{~kg} / \mathrm{d}$ of the total base scenario loading.

The objective function of the NLMM was to minimize the reduction in loading (from the base scenario), and is given as

$$
\text { minimize } \sum_{i=1}^{N M} \sum_{j=1}^{N T} u_{j} N R_{i, j} \text {, }
$$

where

$N M$ is the number of management areas,

$N T$ is the number of management area types, which can be either 1 for existing homes or 2 for future homes, and

$u_{j}$ is a dimensionless unit cost factor for nitrate loading reduction from existing or future homes.

\section{Constraints on Ground-Water Nitrate Concentration}

The value of the objective function was limited by a set of constraints on minimum reductions (relative to base scenario) in ground-water nitrate concentrations, minimum reductions (relative to base scenario) in ground-water discharge nitrate loading to streams, and minimum and maximum loading reductions to the aquifer for existing and future homes in each management area. 


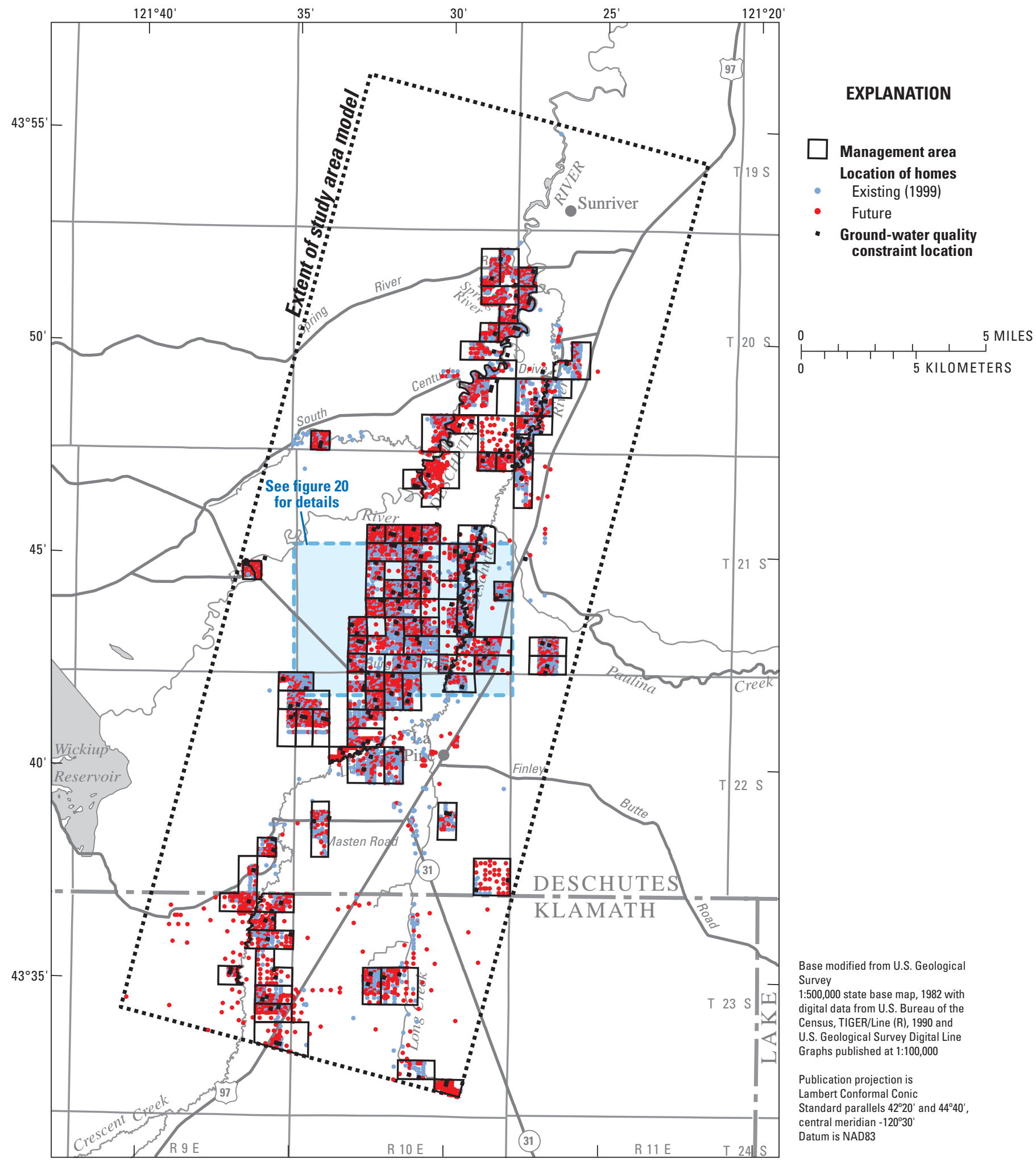

Figure 19. Locations of management areas and ground-water nitrate concentration constraint locations in the Nitrate Loading Management Model for the La Pine, Oregon, study area. 
Minimum reductions in ground-water nitrate concentration constraints were set at 339 locations in the simulation model. The minimum reduction values were determined by simulating the base scenario equilibrium concentration at each location and computing the reduction necessary to meet a specified concentration value. For example, if the base scenario nitrate concentration were calculated by the simulation model to be $23 \mathrm{mg} \mathrm{N} / \mathrm{L}$ and the maximum allowable concentration was $7 \mathrm{mg} \mathrm{N} / \mathrm{L}$, then the minimum reduction constraint at that location would be $16 \mathrm{mg}$ N/L.

Constraints were set at one or two locations in the simulation model for each management area. One point was selected to be sensitive to loading from existing homes and another point was selected to be sensitive to loading from future homes in the management area. The most sensitive locations for existing and future loading were determined by simulating loading only from existing or future homes in a management area and determining the location (cell) in the model where the highest simulated concentrations occurred. If the same location were most sensitive to both existing and future loading from a management area, then only one location was set for that management area.

The model simulates three-dimensional flow and transport; therefore, nitrate concentrations can vary with depth. To account for the variation in concentration with depth, shallow and deep constraints were specified at most locations. The shallow constraint was specified 5-10 ft below the water table (an average of $20 \mathrm{ft}$ below land surface) and the deep constraint was specified immediately above the suboxic boundary (an average of $50 \mathrm{ft}$ below land surface). Four unique constraints (one shallow and one deep for both existing and future homes) specified in each management area for each of the 194 locations where concentration was constrained would have required specified constraints in 388 model cells. However, forty-nine locations were eliminated because the same location was sensitive to loading from both existing and future homes, and some cells were eliminated because the oxic ground-water layer was only two cells thick and only one cell was used. In all, there were 339 concentration constraint cells at 174 locations in the NLMM (fig. 19).

Mathematically, the minimum ground-water concentration reduction constraints were specified as

$$
\mathrm{CRmin}_{\mathrm{k}} \leq \mathrm{CR} \mathrm{m}_{\mathrm{m}, \mathrm{k}} \text {. }
$$

The minimum concentration reduction was computed as

$$
C R \min _{m, k}=\mathrm{Csq}_{m, k}-\mathrm{Cmax}_{\mathrm{k}}
$$

The effect of loading from the 350 homes and lots not included in the NLMM was accounted for by simulating equilibrium concentrations throughout the model that resulted from base scenario loading at these 350 locations. The resulting concentrations at each constraint site were used to adjust the $C R \min _{m, k}$ values at each site.

\section{Constraints on Discharge of Nitrate from Ground Water to Streams}

The simulation model results indicated that nitrate from on-site wastewater systems can reach streams through groundwater discharge. Because the addition of nitrate to streams could have a deleterious effect on stream quality, the NLMM was configured to allow constraints on the amount of nitrate discharged to streams. Constraints on minimum reduction in discharge of nitrate from ground water to streams were specified for 14 reaches on the Deschutes and Little Deschutes Rivers. The minimum reduction values were determined by simulating the base scenario equilibrium ground-water discharge nitrate loading to each reach and computing the reduction necessary to meet a specified discharge constraint. For example, if the base scenario ground-water discharge of nitrate to a reach was determined to be $3 \mathrm{~kg} / \mathrm{d}$ and the specified discharge constraint (maximum allowable discharge of nitrate) was $1 \mathrm{~kg} / \mathrm{d}$, then the minimum reduction for that reach would be $2 \mathrm{~kg} / \mathrm{d}$. Mathematically, the minimum reduction in groundwater discharge nitrate loading to stream constraints were specified as

$$
D R \min _{r} \leq D R_{r}
$$

The minimum discharge loading reduction was computed as

$$
D R \min _{r}=\mathrm{Dsq}_{\mathrm{r}}-\mathrm{D} \max _{\mathrm{r}}
$$

\section{Constraints on Reduction of Nitrate Loading}

Minimum and maximum nitrate loading reduction constraints were specified in the NLMM. Mathematically the constraints were expressed as

$$
\operatorname{NRmin}_{j} \leq N R_{j} \leq \operatorname{NRmax}_{j},
$$

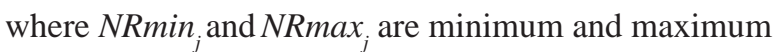
loading reduction constraints for existing $(j=1)$ and future $(j=2)$ homes (units of $\mathrm{kg} / \mathrm{d}$ ). The loading reduction constraints establish minimum or maximum loading reduction constraints on either existing or future homes. 


\section{Response-Matrix Technique for Solution of Nitrate Loading Management Model}

The optimization method used to solve the NLMM is based on a widely applied technique for solving ground-water management problems called the response-matrix technique. The assumption that must be satisfied to use this technique is that the nitrate concentrations at each constraint site are a linear function of the loading rates in each management area. By assuming linearity, determining the nitrate concentration or ground-water discharge loading rate to streams is possible at any location where a constraint is specified by summing the contribution of loading in each management area to the concentration or discharge at that location. The responsematrix technique is described in detail by Gorelick and others (1993) and Ahlfeld and Mulligan (2000). The responsematrix approach has been used to solve ground-water wastemanagement problems similar to the problem evaluated in this work by Moosburner and Wood (1980), Gorelick (1982), and Gorelick and Remson (1982).

The assumption that simulated nitrate concentration and discharge nitrate loading to streams is a linear function of loading to the aquifer was tested through a series of simulations. The loading rate to a single management area was varied in each simulation and the computed nitrate concentrations at several constraint locations (model cells) were recorded. When loading rate was plotted against concentration for each location, the relation was shown to be linear.

One requirement of this technique is that the effect of the sources of nitrate loading on the ground-water velocity field is known because the mass loading of nitrate is the product of the nitrate concentration and hydraulic loading rate of the on-site wastewater systems. Previous workers have assumed that for concentrated pollutant sources, the source-water flow rate (hydraulic loading rate) has a negligible influence on the ground-water velocity field (Gorelick, 1982; Gorelick and Remson, 1982). This also is the assumption used for this study, where recharge from on-site wastewater systems to, and domestic water-supply well withdrawals from, the shallow aquifer are nearly equal, and both are small relative to natural recharge rates. Therefore, the ground-water velocity field without the influence of on-site wastewater systems as sources of recharge was used to simulate transport.

Use of the response-matrix technique requires that response functions for ground-water nitrate concentrations and ground-water discharge of nitrate to streams are calculated at each of the 339 model cells where concentration constraints were specified and the 14 stream reaches where ground-water discharge of nitrate was constrained. The response functions were calculated by making 194 simulations, one for each decision variable (97 management areas, each with decision variables for loading reduction for existing and future homes). The response to base scenario loading from either existing or future homes in a single management area was simulated. The spatial distribution of loading within each management area was at the resolution of a model cell- $500 \mathrm{ft}$ in the $\mathrm{x}$ - and $\mathrm{y}$ dimensions. The purpose of these simulations was to compute the change in concentration at each constraint location caused by a unit change in loading at the location represented by the decisions variable. Calculation of the unit change in concentration was made using initial nitrate concentrations of zero and simulating equilibrium concentrations. The base scenario loading rates $(\mathrm{kg} / \mathrm{d})$ for existing and future homes in management area $\mathrm{i}$ and type $\mathrm{j}$ were defined as $\mathrm{Nsq}_{\mathrm{i}, \mathrm{j}}$. Concentration response coefficients, $\mathrm{rc}_{\mathrm{i}, \mathrm{j}, \mathrm{m}, \mathrm{k}}$, were computed as

$$
r c_{i, j, m, k}=\frac{C s q_{m, k}}{N s q_{i, j}}
$$

Ground-water discharge nitrate loading response coefficients, $r d_{i, j, r}$, for each stream reach were computed as

$$
r d_{i, j, r}=\frac{D s q_{r}}{N s q_{i, j}}
$$

Units of milligrams per liter per kilogram per day were used for concentration response coefficients and groundwater discharge nitrate to stream response coefficients are dimensionless. The magnitude of the response coefficient is directly proportional to the sensitivity of the nitrate concentration or discharge nitrate loading at a constraint site to loading in a management area. This relation is illustrated for the concentration constraint site 31-E-S (fig. 20), which is the shallow concentration constraint site selected for its sensitivity to loading from existing homes in management area 31.

Management area 31 is adjacent to the west bank of the Little Deschutes River, approximately 1 to 1.5 mi north of Burgess Road (fig. 20). The linear response coefficients, $\mathrm{rC}_{\mathrm{i}, \mathrm{j}, \mathrm{k}, \mathrm{m}, \mathrm{for}}$ several nearby management areas and types of homes (existing or future), show that loading in management areas $31,32,50,51,52$, and 53 significantly affect the nitrate concentration at constraint location 31-E-S (table 7). Management areas 48, 49, 63, and 64 have lesser effects. Response coefficient values (table 8) indicate that the nitrate concentration at site 31-E-S is not a simple function of the number of homes in management area 31 or the distance from the site to adjacent management areas. Table 8 shows that the largest influence on concentration at point $31-\mathrm{E}-\mathrm{S}$ is from future homes in area 31, followed by existing homes in areas 31 and 50, future homes in areas 50 and 51, and existing homes in area 51. Response coefficients indicate that management area 32, the closest area to site 31-E-S, has less influence on concentration than more distant areas because of the direction of ground-water flow through the area (toward the Little Deschutes River) and the location of site 31-E-S in relation to homes in area 32. 
Assuming the system is linear, the reduction in nitrate concentration, $C R_{m, k}$, at constraint location $m$ and depth $k$ can be calculated with the concentration response coefficients by summation of the individual concentration reductions caused by reductions in loading to existing and future homes in each management area. The summation is written as

$$
C R_{m, k}=\sum_{i=1}^{N M} \sum_{j=1}^{N T} r C_{i, j, m, k} N R_{i, j}
$$

Similarly, the reduction in ground-water discharge nitrate loading to streams, $D R_{r}$, can be calculated with the discharge loading response coefficients by summation of the individual discharge loading reductions caused by reductions in loading to existing and future homes in each management area. The summation is written as

$$
D R_{r}=\sum_{i=1}^{N M} \sum_{j=1}^{N T} r d_{i, j, r} N R_{i, j}
$$

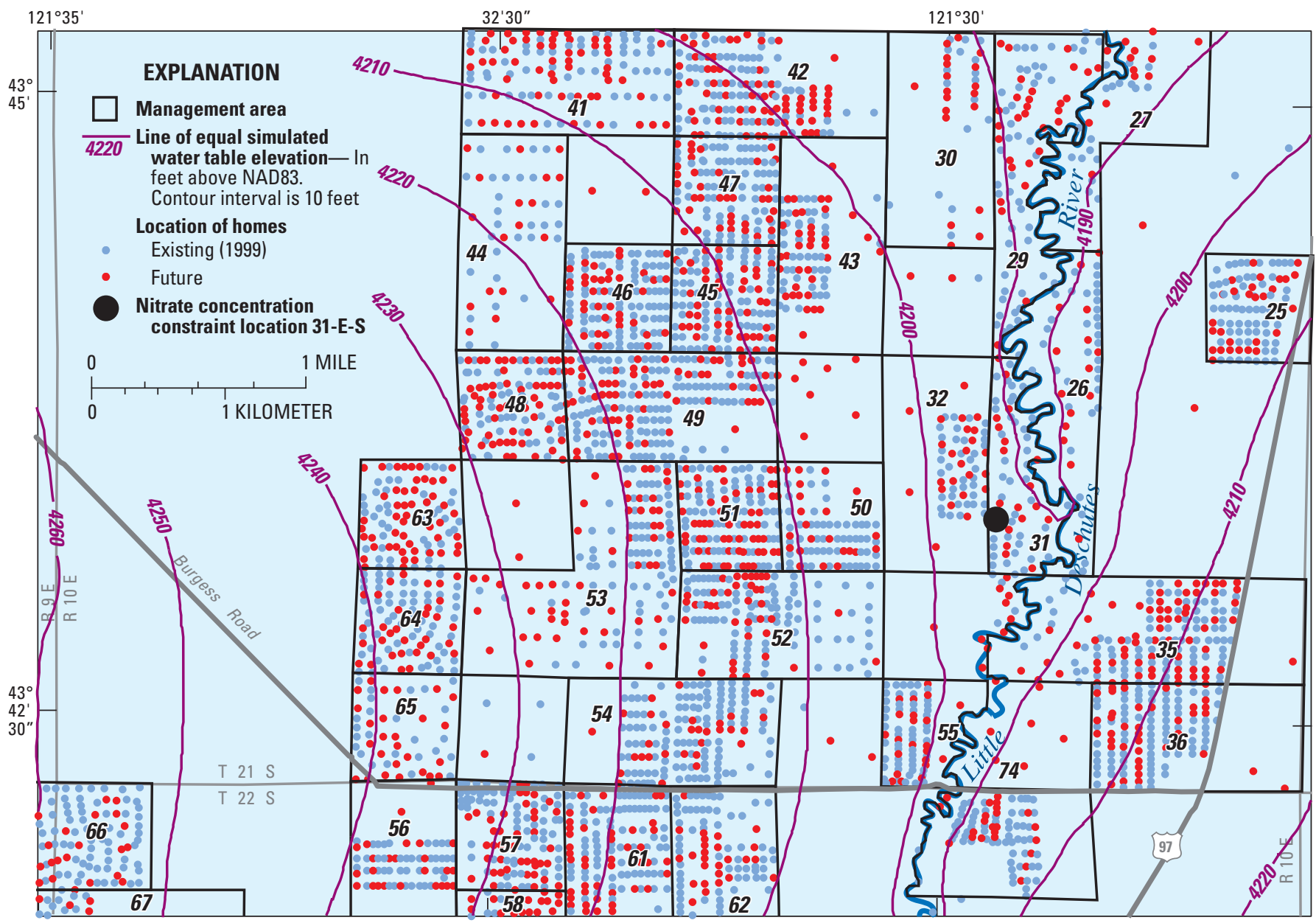

Base modified from U.S. Geological Survey

1:500,000 state base map, 1982 with digital data from U.S. Bureau of the Census, TIGER/Line (R), 1990 and

U.S. Geological Survey Digital Line Graphs published at 1:100,000

Publication projection is Lambert Conformal Conic

Standard parallels $42^{\circ} 20^{\prime}$ and $44^{\circ} 40^{\prime}$, central meridian $-120^{\circ} 30^{\prime}$ Datum is North American Datum of 1983

Figure 20. Locations of management areas near Burgess Road and management area 31 in the La Pine, Oregon, study area. 
Table 8. Response coefficients relating the effects of loading in nearby areas to the nitrate concentration at a constraint location in management area 31 in the La Pine, Oregon, study area.

[M anagement area: 31-site 31-E-S in figure 20. Response coefficients are in milligrams per liter per kilogram per day loading]

\begin{tabular}{clc}
\hline $\begin{array}{c}\text { Management } \\
\text { area }\end{array}$ & Type & $\begin{array}{c}\text { Response } \\
\text { coefficient }\end{array}$ \\
\hline 31 & Future & 14.85 \\
50 & Existing & 11.10 \\
31 & Existing & 9.92 \\
50 & Future & 8.85 \\
51 & Future & 3.49 \\
51 & Existing & 3.07 \\
32 & Future & 1.71 \\
52 & Future & 1.56 \\
52 & Existing & 1.31 \\
53 & Existing & 0.75 \\
32 & Existing & 0.74 \\
53 & Future & 0.50 \\
63 & Existing & 0.15 \\
63 & Future & 0.15 \\
64 & Existing & 0.03 \\
64 & Future & 0.02 \\
49 & Existing & 0.01 \\
49 & Future & 0.01 \\
48 & Future & 0.01 \\
48 & Existing & 0.01 \\
\hline
\end{tabular}

These summations include 194 terms because there are 97 management areas (NM) and 2 loading types (NT), existing and future homes, in each management area. In each summation, however, many terms are equal to zero because the response coefficients are zero; this occurs when concentration or discharge loading at a constraint location does not affect loading in a management area.

The response matrix was prepared by running one simulation for each decision variable in which loading was applied only at the locations defined for that decision variable (for example, existing homes in management area 31 ). The loading rate and resulting concentrations at each of the constraint locations were used to compute the response coefficient at each constraint location using equations 5 and $\underline{6}$. A set of utility programs and scripts were developed to run the 194 simulations, extract the simulated concentration values at constraint sites, compute the response coefficients, and format the coefficients into a matrix for input to the optimization program.
Response coefficients are the link between the simulation model and the NLMM. The response coefficients are utilized by the NLMM by replacing $C R_{m k}$ (equation 2 ) with the righthand side of equation 7 and replacing $D R_{r}$ (equation 3) with the right hand side of equation 8 . The constraints for reduction in nitrate concentration and discharge loading to streams are then written as

$$
C R \min _{m, k} \leq \sum_{i=1}^{N M} \sum_{j=1}^{N T} r c_{i, j, m, k} N R_{i, j},
$$

and

$$
D R \min _{r} \leq \sum_{i=1}^{N M} \sum_{j=1}^{N T} r d_{i, j, r} N R_{i, j} .
$$

\section{$\underline{\text { Equations } 9}$ and 10 replace equations 2 and $\underline{3}$ in the NLMM. \\ The modified NLMM, defined by equations 1} (objective function), $\underline{4}$ (loading constraints), $\underline{9}$ (concentration constraints), and $\underline{10}$ (discharge loading constraints), constitutes a linear program. This program was solved using the "What's Best!" optimization program (LINDO Systems, 2003). This set of solvers is implemented as an add-in to Microsoft Excel. The response matrix and constraint definitions are defined in the spreadsheet using special functions provided in the "What's Best!" add-in. The NLMM can mathematically search for the minimum nitrate loading reductions for existing and future homes in each management area that satisfy the constraints on nitrate concentrations in ground water and ground-water discharge loading of nitrate to streams. The program also identifies management problems that are not feasible. This occurs when at least one constraint cannot be met with any combination of decision variable values.

\section{Application of Model}

In the application of the La Pine NLMM described here, the values of constraints were varied in a sensitivity analysis to explore relations between constraint values and optimal loading rates to the aquifer. The three constraint options used in the NLMM were varied and optimal solutions were computed to demonstrate how decision makers might use the model in a trade-off analysis to determine the effect of constraint values on the objective of minimizing nitrate loading reductions. The NLMM also was used to evaluate the influence of a cost variable that accounts for differential costs in reducing nitrate loading from existing and future homes. 


\section{Sensitivity of Optimal Solution to Water-Quality Constraints}

\section{Ground-Water Nitrate Concentration}

Ground-water concentration constraints were specified at as many as two locations for each management area: one location was the most sensitive to loading from existing homes in that management area, and one location was most sensitive to loading from future homes. In 20 management areas, the same location was most sensitive for both existing and future homes. A shallow constraint was specified near the water table at each these 174 locations (fig. 19). In addition, where the oxic part of the aquifer was greater than 10-ft thick (163 locations), a deep constraint was specified. As described in the discussion of the model formulation, the concentration constraint values, $C R \min _{m, k}$, were computed (equation $2 \mathrm{a}$ ) as the minimum reduction from base scenario concentration that would be required to meet a specified concentration limit, $C \max _{\mathrm{k}}$.

Concentration constraints were varied to show the relative sensitivity of optimal loading solutions to constraints in different parts of the aquifer system. The total nitrate loading for existing and future homes in all 97 management areas was summed for each optimal solution to provide a basis for comparing the sensitivity of the solutions to values of the concentration constraints. The NLMM was solved using a range of 1 to $25 \mathrm{mg} \mathrm{N} / \mathrm{L}$ for the maximum allowable concentration values for both the shallow $\left(\mathrm{Cmax}_{\mathrm{s}}\right)$ and deep $\left(\mathrm{C} \max _{d}\right)$ constraint locations. This range was selected because it includes most of the range of values that would constrain, or bind, the optimal solution. Binding constraints limit the amount of loading to the aquifer. Nonbinding constraints do not limit the loading to the aquifer system, because of their value or location.

The NLMM was used to compute optimal nitrate loading rates for various combinations of shallow and deep concentration constraints (fig. 21). Optimal solutions were most sensitive to concentration constraints in the shallow part of the ground-water system. This result was expected because concentrations are greatest at the water table where loading occurs, and decrease with depth and distance downgradient from the source. The base scenario loading used in the NLMM was $190 \mathrm{~kg} / \mathrm{d}(153,000 \mathrm{lb} / \mathrm{yr})$ and, as expected, this is the optimal loading solution for the case where there are no constraints specified. Curve A (fig. 21) shows the effect on optimal loading when concentrations are constrained only in the deep part of the system. Deep constraints do not limit optimal loading until constraint values are less than $10 \mathrm{mg} \mathrm{N} / \mathrm{L}$ (point C, fig. 21). Specifying a nitrate concentration constraint of $1 \mathrm{mg} \mathrm{N} / \mathrm{L}$ in the deep part of the aquifer limited optimal loading to $110 \mathrm{~kg} / \mathrm{d}$ (point D). Curve B shows the effect on optimal loading when concentrations are constrained only in the shallow part of the system. Shallow constraints limit optimal loading throughout the range, with loading limited to $17 \mathrm{~kg} / \mathrm{d}$ at a constraint value of $1 \mathrm{mg} \mathrm{N} / \mathrm{L}$ (point E) and $168 \mathrm{~kg} / \mathrm{d}$ at a constraint value of $25 \mathrm{mg} \mathrm{N} / \mathrm{L}$ (point F). If a regulatory limit, such as the ODEQ "action level" of $7 \mathrm{mg} \mathrm{N} / \mathrm{L}$ is applied to the shallow constraints (and no deep constraints are specified), optimal loading is reduced to $84 \mathrm{~kg} / \mathrm{d}$ (point G) - a 56 percent reduction from base scenario loading. For comparison, if no shallow constraints are specified and $7 \mathrm{mg}$ $\mathrm{N} / \mathrm{L}$ is applied to the deep constraints, optimal loading is reduced very little, to $183 \mathrm{~kg} / \mathrm{d}$ (point $\mathrm{H}$ ). Loading sensitivity curves also are shown in figure 21 for shallow concentration constraint $\left(\operatorname{Cmax}_{s}\right)$ values of 5, 10, 15, 20, and $25 \mathrm{mg} \mathrm{N} / \mathrm{L}$; these curves were constructed by keeping the shallow constraint constant at the indicated value and varying the value of the deep constraint. For example, with shallow and deep constraints of 5 and $15 \mathrm{mg} \mathrm{N} / \mathrm{L}$ respectively (point I), the optimal loading is $65 \mathrm{~kg} / \mathrm{d}$. For reference, the optimal loading for shallow and deep concentration constraints of 7 and $3 \mathrm{mg} \mathrm{N} / \mathrm{L}$, respectively, is $84 \mathrm{~kg} / \mathrm{d}$ and plots at point $\mathrm{J}$ in figure 21. The effects of more- or less-stringent concentration constraints on nitrate loading in the shallow and deep parts of the ground-water system can be analyzed using figure 21 .

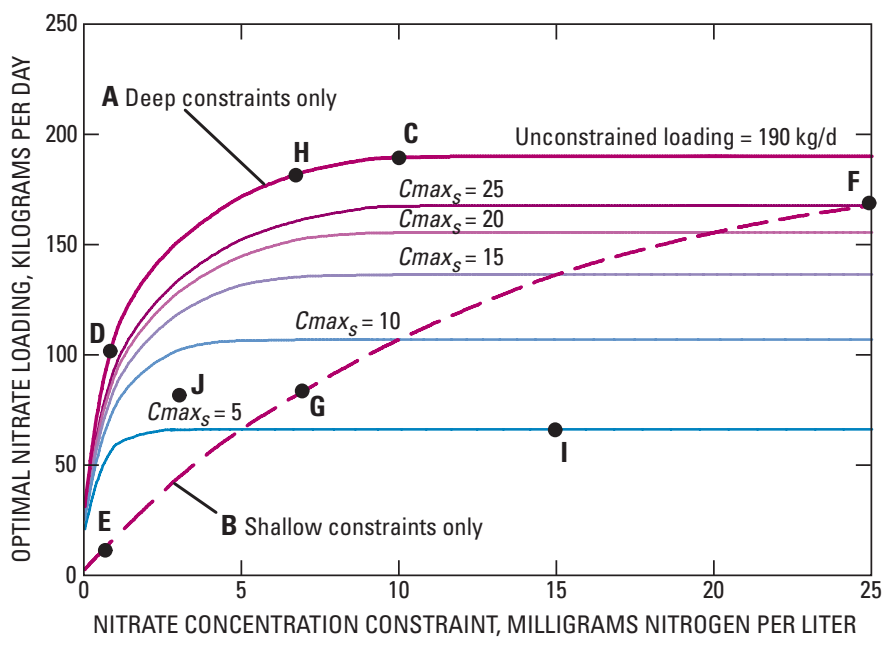

EXPLANATION

Curve A-Relation between optimal loading and values of concentration constraints at deep locations

Curve B-Relation between optimal loading and values of concentration constraints at shallow locations

Points C-J-Optimal loading for combinations of shallow and deep concentration constraints

C-Deep constraints set to $10 \mathrm{mg} \mathrm{N} / \mathrm{L}$, no shallow constraints D-Deep constraints set to $1 \mathrm{mg} \mathrm{N} / \mathrm{L}$, no shallow constraints E-Shallow constraints set to $1 \mathrm{mg} \mathrm{N} / \mathrm{L}$, no deep constraints F-Shallow constraints set to $25 \mathrm{mg} \mathrm{N} / \mathrm{L}$, no deep constraints G-Shallow constraints set to $7 \mathrm{mg} \mathrm{N} / \mathrm{L}$, no deep constraints H-Deep constraints set to $7 \mathrm{mg} \mathrm{N} / \mathrm{L}$, no shallow constraints I-Shallow constraints set to $5 \mathrm{mg} \mathrm{N} / \mathrm{L}$, deep constraints set to $15 \mathrm{mg} \mathrm{N} / \mathrm{L}$ J-Shallow constraints set to $7 \mathrm{mg} \mathrm{N} / \mathrm{L}$, deep constraints set to $3 \mathrm{mg} \mathrm{N} / \mathrm{L}$

Figure 21. Sensitivity of optimal loading solutions to ground-water nitrate concentration constraints in the $\mathrm{La}$ Pine, Oregon, study area. 


\section{Evaluation of Approaches for Managing Nitate Loading from On-Site Wastewater Systems near La Pine, Oregon}

These results can be used to assess trade-offs in protection of water quality in the shallow and deep parts of the aquifer. Few wells in the La Pine area are open to the upper $10 \mathrm{ft}$ of the aquifer where the shallow constraints are specified. Using these results, decision makers could evaluate the cost, in terms of reduced loading, of protecting the shallowest part of the system (within $10 \mathrm{ft}$ of the water table) to the same degree as the deeper part of the system (30-50 below the water table), where most domestic wells obtain water.

\section{Ground-Water Nitrate Discharge Loading to Streams}

Fourteen stream reaches were defined where constraints could be applied to ground-water nitrate discharge loading. As described in the discussion of the model formulation, the discharge loading constraint values, DRmin, were computed (equation 3a) as the minimum reduction from base scenario discharge loading that would be required to meet a specified limit, D max ${ }_{r}$. The beginning and end of each reach were selected to coincide with confluences or road crossings.

The purpose of this analysis was to demonstrate how the NLMM can be used to conjunctively manage water quality of ground-water and surface-water resources using optimization techniques. Discharge loading constraints were specified by setting a minimum percent reduction from base scenario ground-water discharge loading to streams. To determine the sensitivity to discharge loading constraints, the percent reduction was varied from 0 to 99 percent. Two sets of solutions were computed with NLMM: 1) with no constraints on ground-water concentrations, and 2) with shallow and deep ground-water concentration constraints of 7 and $3 \mathrm{mg}$ N/L. Without concentration constraints, the discharge loading constraint directly limited the loading to streams as would be expected based on the formulation of the model (fig. 22). However, with the limitations imposed on loading by concentration constraints ( 7 and $3 \mathrm{mg} \mathrm{N} / \mathrm{L}$ ), discharge loading constraints had no effect on loading to streams until the constraint values were greater than about 50 percent reduction (fig. 22). At values greater than 50 percent, most loading reductions required to meet this constraint are needed in the management areas adjacent to streams, where, according to simulation results, shallow ground-water flow paths through the thin oxic part of the ground-water system are connected to the streams. With no concentration constraints and discharge loading to streams constrained to a minimum reduction of 97 percent, the total loading to the system is about $100 \mathrm{~kg} / \mathrm{d}$. By comparison, constraining concentration to 7 and $3 \mathrm{mg} \mathrm{N} / \mathrm{L}$ (shallow and deep, respectively) and constraining discharge loading reduction to at least 97 percent requires that total loading be reduced to about $40 \mathrm{~kg} / \mathrm{d}$ (fig. 22). The additional reduction in total loading required to meet the ground-water concentration constraints, $60 \mathrm{~kg} / \mathrm{d}$, reflects the additional costs of management strategies designed to protect both ground-water quality and stream quality.

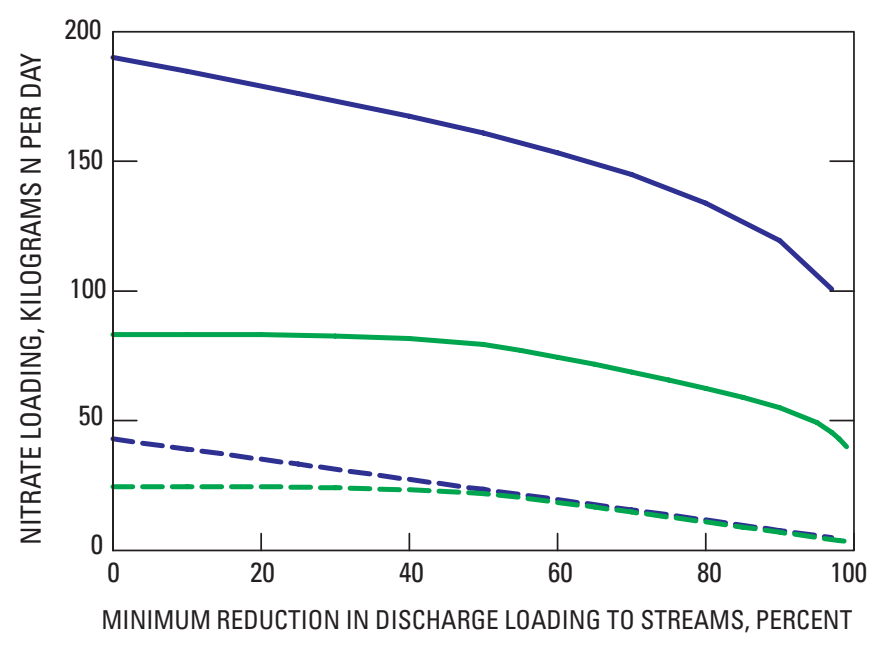

\section{EXPLANATION}

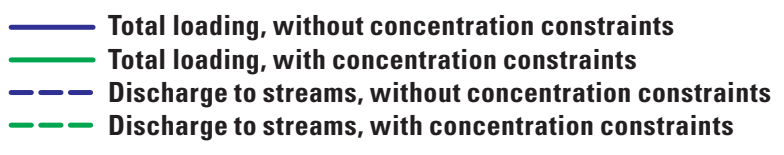

Figure 22. Sensitivity of optimal loading solutions to constraints on the minimum reduction in ground-water discharge loading to streams in the La Pine, Oregon, study area.

These results can be used to assess trade-offs in the protection of surface-water quality. To make decisions on the values of discharge constraints, the processes affecting nitrate as it is transported through the near stream and riparian environments need to be better understood (Hinkle and others, 2007b). The simulation model uses simple assumptions regarding the fate and transport of nitrate in this part of the ground-water system and the estimates of ground-water discharge of nitrate to streams should be considered the upper limits of possible discharge.

\section{Sensitivity of Optimal Solution to Nitrate Loading Constraints}

Minimum and maximum loading reduction constraints, NRmin and NRmax in equation 4, can be specified for existing or future homes in the NLMM. The constraints are computed as a percentage of the base scenario loading for the existing or future homes in each management area. For example, if base scenario loading for future homes in a management area is $2 \mathrm{~kg} / \mathrm{d}$, and the desired loading reduction is a minimum of 25 percent of status-quo build-out loading, then NR min would be equal to $0.5 \mathrm{~kg} / \mathrm{d}$. 
In this example, the loading constraints were used to evaluate how specifying minimum nitrate reduction standards for future homes would affect the overall loading and the proportion of loading from existing homes. As formulated, the NLMM also offers the ability to specify other constraints on loading reduction, such as maximum loading reduction for either future of existing homes. This type of constraint could be used to reflect the limitations of alternative treatment systems to reduce loading by more than a specified percentage.

Optimal solutions were computed in which the minimum reduction constraint for future homes varied and all other constraints were constant. Ground-water concentration constraints of 7 and $3 \mathrm{mg} \mathrm{N} / \mathrm{L}$ were specified for the shallow and deep sites, respectively, and ground-water discharge nitrate loading to streams was unconstrained. All existing on-site wastewater systems in the study area are assumed to discharge effluent with $46 \mathrm{mg} \mathrm{N} / \mathrm{L}$ nitrate, and this was the performance level used to compute the base scenario loading of $190 \mathrm{~kg} / \mathrm{d}$. Maximum loading reduction constraints were 96 percent of base scenario loading for both existing and future homes; this constraint reflects the assumption that the best attainable on-site wastewater system performance is $2 \mathrm{mg} \mathrm{N} / \mathrm{L}$. The minimum loading reduction constraint for future homes was specified on the basis of assumed performance standards for on-site wastewater systems that ranged from 2 to $46 \mathrm{mg} \mathrm{N} / \mathrm{L}$ concentration in effluent that recharged the ground-water system. Thus, in this series of solutions, the $46 \mathrm{mg} \mathrm{N} / \mathrm{L}$ performance level was the equivalent of zero reduction from base scenario loading. The other performance levels used were 2, 10, 20, and $30 \mathrm{mg} \mathrm{N} / \mathrm{L}$, corresponding to minimum loading reductions of $96,78,57$, and 35 percent, respectively (fig. 23).

Under base scenario conditions, existing and future homes will contribute 104 and $86 \mathrm{~kg} / \mathrm{d}$, respectively, to the total loading of $190 \mathrm{~kg} / \mathrm{d}$. The results of this analysis show that as the minimum loading reduction constraint for future homes is increased from 0 to 96 percent, optimal loading from future homes decreases from 38 to $3 \mathrm{~kg} / \mathrm{d}$ and the associated total loading decreases from 84 to $58 \mathrm{~kg} / \mathrm{d}$.

The reduction in loading to the aquifer from future homes implemented using a minimum reduction constraint allows higher loading rates to be maintained from existing homes while still meeting concentration constraints. If no loading reduction is required for future homes, loading from existing homes will have to be reduced by 56 percent (from 104 to $46 \mathrm{~kg} / \mathrm{d}$ ). By requiring improved performance of on-site wastewater systems in future homes, there is less need for loading reduction from existing homes. For example, if a 96 percent reduction requirement is imposed for future homes, loading from existing homes would have to be reduced by only

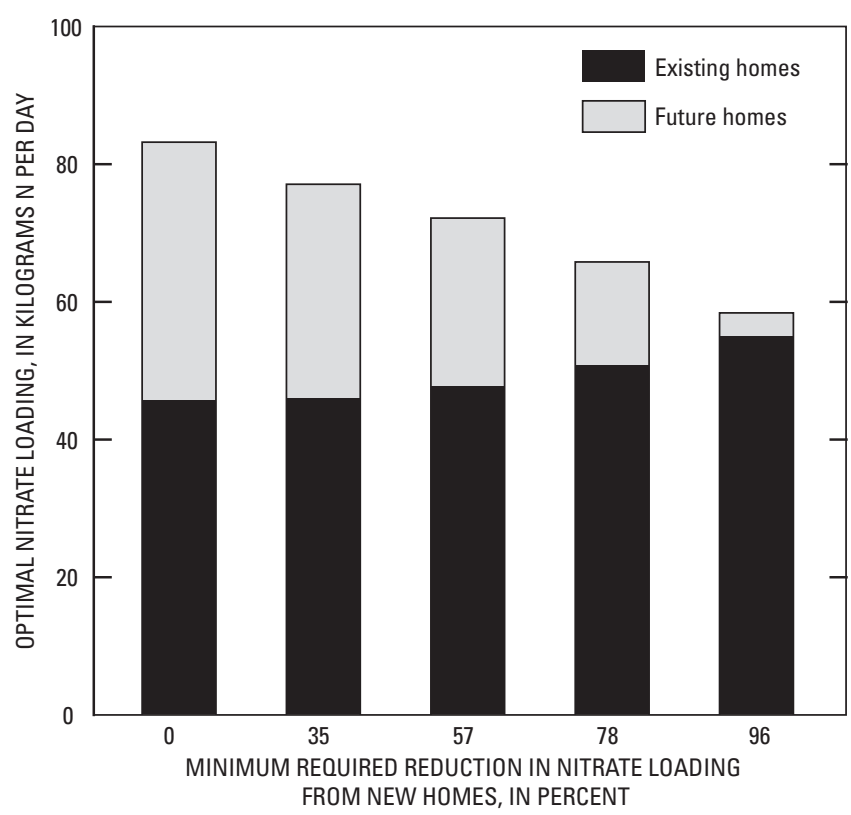

Figure 23. Sensitivity of optimal solution to minimum decentralized wastewater treatment performance standards for future homes in the La Pine, Oregon, study area.

47 percent to meet ground-water concentration constraints of 7 and $3 \mathrm{mg} \mathrm{N} / \mathrm{L}$ for shallow and deep parts of the aquifer. If it were less costly to reduce loading from future homes by installing advanced treatment on-site wastewater systems than requiring existing homes to be retrofitted with advanced treatment on-site wastewater systems, then using this type of constraint in the NLMM would allow planners to incorporate specific on-site wastewater system performance standards for future homes into the optimal solution.

\section{Sensitivity of Optimal Solution to Cost Factors}

The simulation model accounts for the physical and geochemical complexities of the ground-water system and this information is available to the NLMM through the response coefficients that were computed using the study area simulation model. Other variables (external to the simulation model) also can be important in determining the optimal nitrate loading solution. The cost of implementing management strategies is the most common external variable that affects management decisions. In many optimization problems, the objective is to minimize the cost of satisfying the constraints on the problem. 
Reducing loading from on-site wastewater systems can incur significant costs whether by limiting housing density or installing and maintaining advanced treatment on-site wastewater systems. The cost factor of reducing nitrate loading, $u_{j}$ in equation 1 of the NLMM, can be used to account for differences in cost for existing and future homes. If the cost of nitrate reduction varies among decision variables in other ways, such as geographically, cost variables can be specified for individual management areas.

The sensitivity of the La Pine NLMM to differences in the cost of reducing nitrate loading from existing and future homes was evaluated by computing the optimal loading solutions for a range of unit cost ratios. Arbitrary cost factors were specified that resulted in ratios of existing to future unit costs ranging from 0.11 (1:9) to 9.0 (9:1). For example, for a cost ratio of 0.11 , the cost factors for existing and future loading reduction were 1 and 9, meaning that it was 9 times more costly to reduce nitrate loading from future homes. To define the extremes, two additional solutions were computed in which the unit cost was set to zero, first for existing, and then for future homes. The only constraints were ground-water concentration constraints of 7 and $3 \mathrm{mg} \mathrm{N} / \mathrm{L}$ for the shallow and deep sites. The loading from existing and future homes for each cost ratio are shown in figure 24.

The highest optimal total loading $(84 \mathrm{~kg} / \mathrm{d})$ occurs when the cost ratio (existing:future) is 1.0 (costs are equal). As the ratio increases or decreases to favor reductions in future or existing homes, respectively, the optimal balance in loading is affected because the objective function (to minimize cost) is most efficiently reduced by eliminating loading from homes that have the lowest cost per unit reduction. As the cost ratio increases or decreases from 1.0, the total loading that can be maintained decreases because cost variables now act as weighting factors that partially determine which management areas and home types will have reduced loading. It is not likely that the ratio of unit costs would fall outside the range of 0.43 to 2.33 , within which the effect on total loading is relatively small. The relative contributions to loading from existing and future homes, however, do vary significantly within this range. This indicates that wherever possible, true cost factors should be incorporated into the NLMM to account for this important external variable.

\section{Spatial Distribution of Loading for Optimal Solution}

The NLMM computes the minimum loading reduction needed from existing and future homes in each management area to achieve the water-quality goals prescribed by a constraint set. To illustrate the variation in optimal loading between management areas, optimal reductions in loading rates to each management area from both existing and future homes were mapped for a specific set of constraints. The constraints for this solution included (1) ground-water nitrate concentrations could not exceed $7 \mathrm{mg}$ N/L at shallow locations and $3 \mathrm{mg} \mathrm{N} / \mathrm{L}$ at deep locations, and (2) the maximum loading reduction possible for either existing or future homes was 96 percent. The ground-water concentration limits were selected to reflect the goals of minimizing loading reductions and insuring protection of the part of the aquifer (30 to $50 \mathrm{ft}$ below the water table) where most domestic wells obtain water. The 96 percent limit on loading reduction is consistent with data from the La Pine NDP that show that the best-performing advanced treatment on-site wastewater systems tested are capable of reducing nitrogen to about $2 \mathrm{mg}$ N/L as nitrate in effluent leaving the drain field. No constraints were placed on discharge of nitrate to streams or minimum loading reduction and no differential cost factors were included.

The optimal minimum reductions vary over a broad range in the 97 management areas. The breadth of the range is a reflection of the complex relations between development location and density, hydrogeology, and geochemical processes. For the specified constraints, the optimal reduction in total loading is $107 \mathrm{~kg} / \mathrm{d}$, or 56 percent of the $190 \mathrm{~kg} / \mathrm{d}$ of loading projected for the base scenario. Contributions to buildout loading were reduced from 104 to $46 \mathrm{~kg} / \mathrm{d}$ for existing

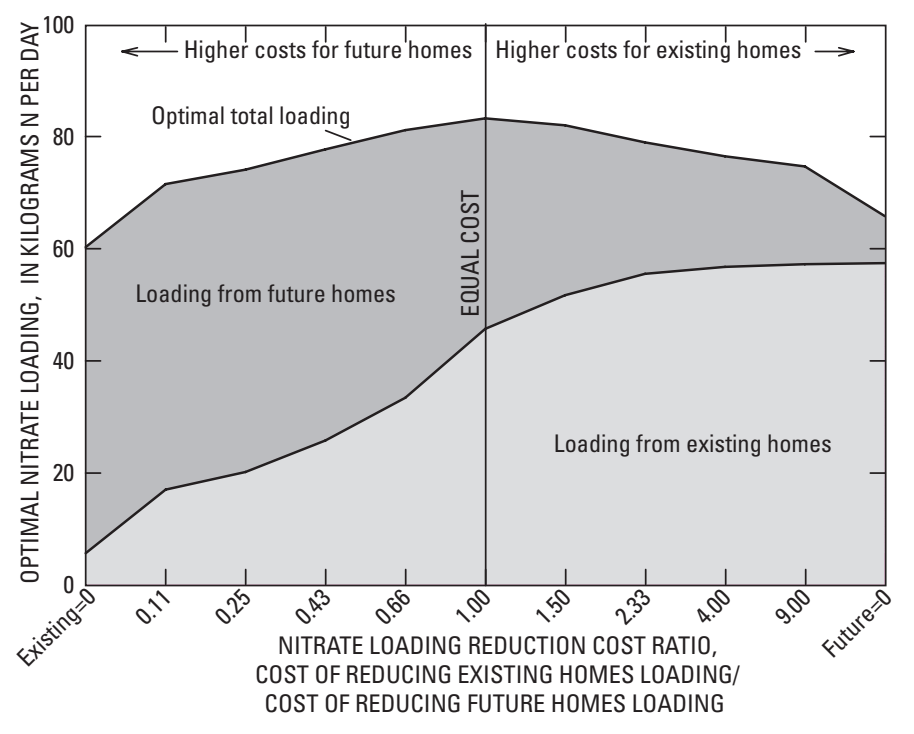

Figure 24. Sensitivity of optimal solutions to relative cost difference of nitrate loading reduction for existing and future homes in the La Pine, Oregon, study area. 
homes and from 86 to $38 \mathrm{~kg} / \mathrm{d}$ for future homes. The optimal reductions in each management area for existing and future homes are shown in figures 25 and $\underline{26}$, respectively.

Overall, the loading from existing homes was reduced by the same proportion, 56 percent, as the loading from future homes because there was roughly the same number of existing and future homes (undeveloped lots) in 2000. Locally, the reductions in loading from existing and future homes for individual management areas often were quite different. For example, in management area 33, where most lots had been developed by 2000, loading from existing homes and future homes would need to be reduced by 81 and 67 percent, respectively (figs. 25, 26). Even fewer undeveloped lots were in the adjacent management area 34 and the entire loading reduction needed to meet concentration constraints (93 percent) would need to come from existing homes.

To further validate the assumption that the simulated nitrate concentrations and ground-water discharge nitrate loading to streams were linear functions of nitrate loading to the aquifer, the base scenario loading (scenario 1) was reduced in each management area by the percentages computed using the NLMM (figs. 25, 26). This loading was used as input to the study-area simulation model and the equilibrium nitrate concentrations and discharge loading to streams simulated by the study-area model were compared to the values computed by the NLMM at the 339 concentration and 14 discharge loading constraint locations and reaches. The simulated concentrations and discharge loading were equal to the values computed by the NLMM using the response coefficients at all constraint locations and reaches. The detailed spatial distribution of loading reduction illustrated in this example could be used by decision makers to delineate ground-water protection zones and set performance standards for on-site wastewater systems to achieve the needed loading reductions.

\section{Comparison of Scenario Simulations and Optimal Solution}

Simulated ground-water nitrate concentrations were used to compare the results of the scenario simulations with the results of an optimal solution computed using the NLMM. For the comparison, concentration values were compiled at the 339 NLMM constraint locations (fig. 19) for four of the scenarios simulated using the simulation model in a "trialand-error" mode. The four scenarios $(1,3,5$, and 7 in table 6) specified on-site wastewater concentrations at the water table of 46, 20, 10, and $2 \mathrm{mg} \mathrm{N} / \mathrm{L}$, respectively. For this analysis, a fifth scenario using a wastewater concentration of $30 \mathrm{mg} \mathrm{N} / \mathrm{L}$ also was simulated. Scenario 1 was the base scenario where conventional on-site wastewater systems yield $46 \mathrm{mg}$ N/L nitrate at the water table. The other four scenarios are based on the assumption that all existing and future homes would install advanced treatment on-site wastewater systems that reduce loading to the same standard. The optimal solution used in the comparison is that in which ground-water nitrate concentrations could not exceed $7 \mathrm{mg} \mathrm{N} / \mathrm{L}$ at shallow sites and $3 \mathrm{mg} \mathrm{N} / \mathrm{L}$ at deep sites, and the maximum loading reduction possible for either existing or future homes was 96 percent.

The relative effectiveness of the management alternatives used in each scenario was evaluated by comparing waterquality improvements (as measured by the percentage of constraint locations with nitrate concentrations greater than $7 \mathrm{mg} \mathrm{N} / \mathrm{L}$ ) with reduced loading for the scenarios and the optimal solution (fig. 27). The base scenario (no loading reduction) resulted in equilibrium concentrations greater than $7 \mathrm{mg} \mathrm{N} / \mathrm{L}$ for 46 percent of the constraint locations. Using advanced treatment systems that can produce nitrate concentrations of 30, 20,10, and $2 \mathrm{mg} \mathrm{N} / \mathrm{L}$, reduced loading by $35,57,78$, and 96 percent and reduced the fraction of constraint locations where ground-water concentrations exceeded $7 \mathrm{mg} \mathrm{N} / \mathrm{L}$ to $36,26,8$, and 1 percent, respectively.

The optimal solution would reduce total loading by 56 percent, and yet had only 3 constraint locations ( $<1$ percent) with concentrations greater than $7 \mathrm{mg} \mathrm{N} / \mathrm{L}$. These three locations were affected by a small amount of unmanaged loading from dispersed homes not included in the NLMM. Loading reduction for the optimal solution was $106 \mathrm{~kg} / \mathrm{d}$, which was nearly equivalent to the loading reduction in the $20 \mathrm{mg}$ N/L scenario (3), in which 26 percent of the sites had concentrations greater than $7 \mathrm{mg} \mathrm{N} / \mathrm{L}$. The $10 \mathrm{mg} \mathrm{N} / \mathrm{L}$ and $2 \mathrm{mg} \mathrm{N} / \mathrm{L}$ scenarios (5 and 7, respectively) are approximately equivalent to the optimal solution in reducing nitrate concentrations in ground water. Because they apply uniform management strategies, however, loading must be reduced by 40-69 percent more than would be required under the optimal solution to achieve similar results.

The scenarios are based on uniform management strategies (for example, all new homes have advanced treatment on-site wastewater systems and all existing systems are replaced), whereas the optimal solution implements loading reductions only where reductions are needed to meet quality constraints. Decision makers would unlikely be able to implement the optimal solution exactly because it would be difficult to have variable on-site wastewater system performance requirements across management areas as small as those defined in the NLMM. More likely, decentralized wastewater treatment would be managed over larger areas that have similar nitrate loading capacity in the NLMM solution. This approach could increase the overall loading reduction required to meet water-quality standards, but still be less costly than uniform management strategies. 


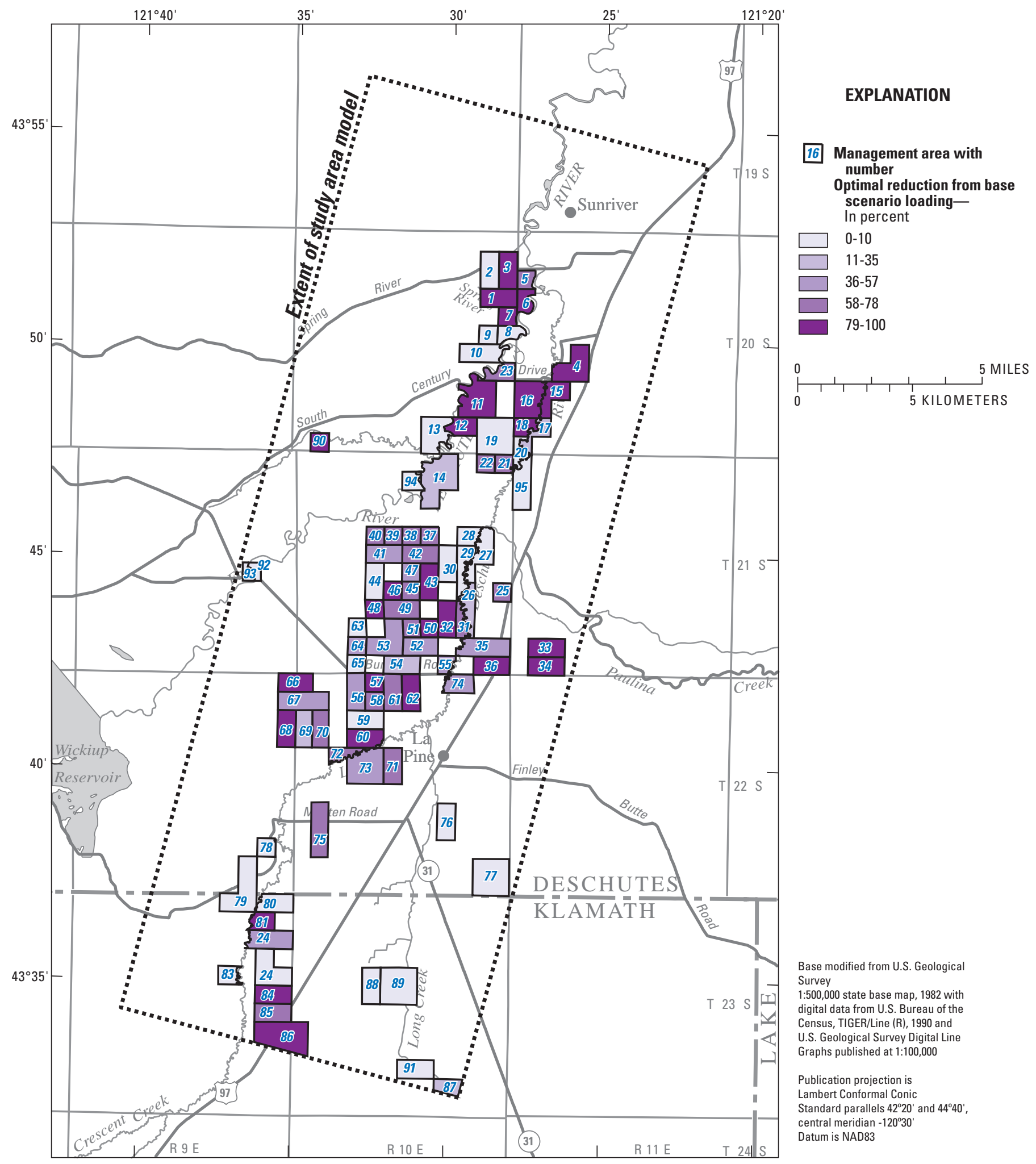

Figure 25. Optimal reduction in nitrate loading from existing homes in the La Pine, Oregon, study area. 


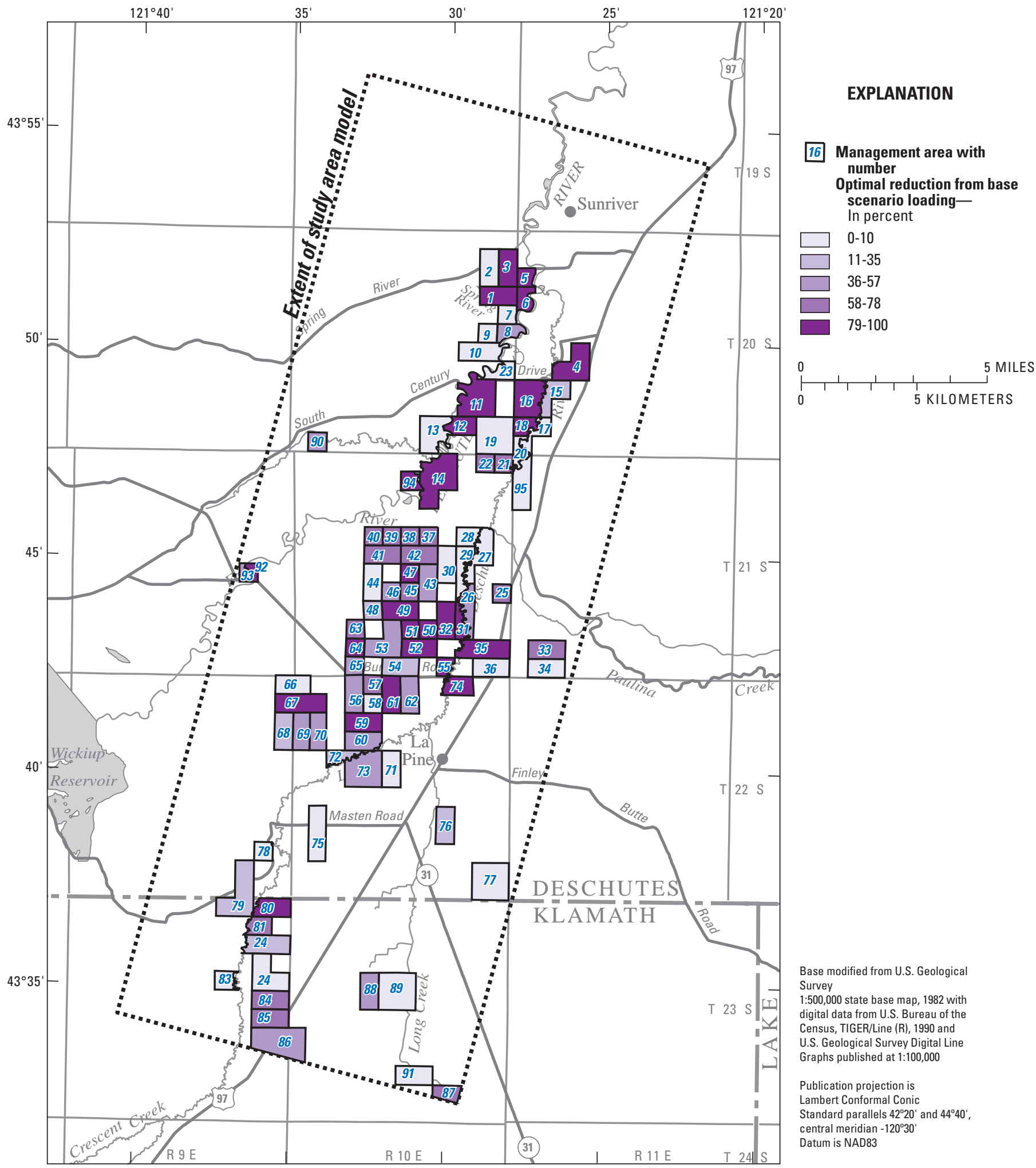

Figure 26. Optimal reduction in nitrate loading from future homes in the La Pine, Oregon, study area. 

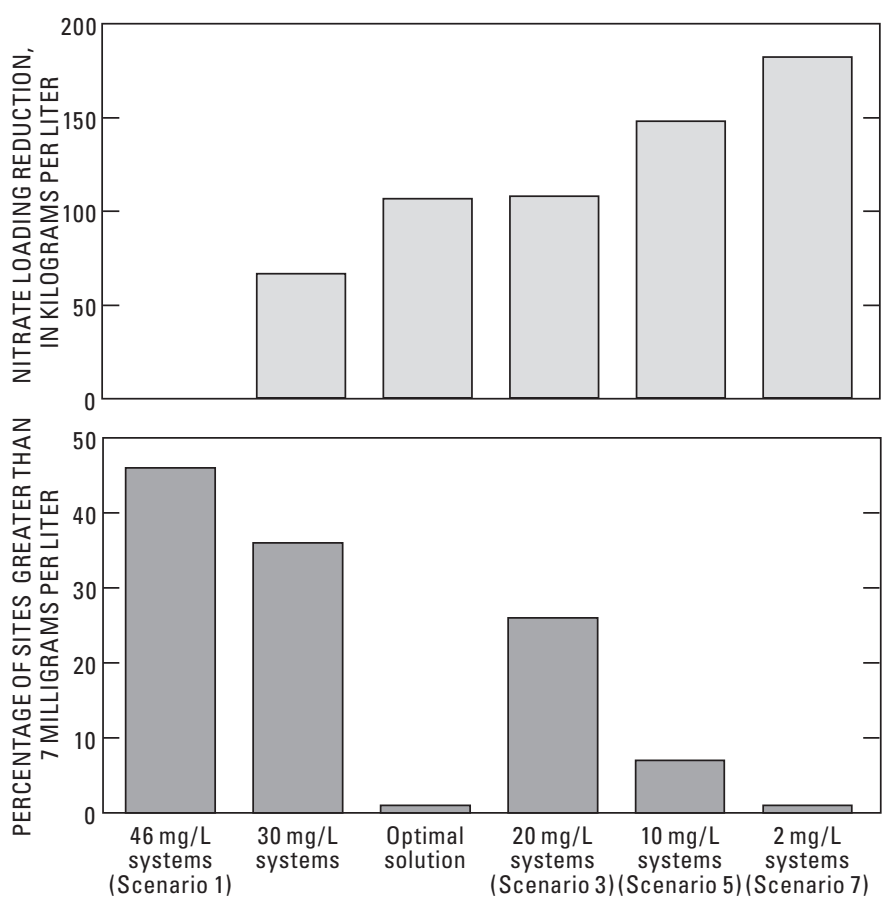

Figure 27. Comparison of loading and water quality between optimal and nonoptimal management scenarios for the La Pine, Oregon, study area.

\section{Limitations and Appropriate Use of Models}

The transect and study-area simulation models were developed to generate a better understanding of the fate and transport of nitrate from on-site wastewater systems at multiple scales. The study-area model also may be used to help evaluate alternative options for management of nitrate loading from on-site wastewater systems. Limitations of the modeling software, assumptions made during model development, and results of model calibration and sensitivity analysis all are factors that constrain the appropriate use of these models and highlight potential future improvements.

A simulation model is a means for testing a conceptual understanding of a system. Because ground-water flow systems are inherently complex, simplifying assumptions must be made in developing and applying model codes (Anderson and Woessner, 1992). Models solve for average conditions (for example, head or nitrate concentrations) within each cell using parameters which are interpolated or extrapolated from measurements, and (or) estimated during calibration. Practical limitations on model size, and hence minimum cell size, are imposed by the size and speed of available computers. More commonly, however, it is the availability of data to define the system that limits the scale and accuracy of the model. In light of this, the intent in developing the simulation models was not to reproduce every detail of the natural system, but to portray its important characteristics in sufficient detail to provide a useful tool for testing the conceptual model and evaluating alternative management options.

\section{Simulation Models}

The study-area simulation model is a decision-support tool for evaluating the effects of wastewater management alternatives on ground-water and surface-water quality at the neighborhood to watershed scale. The study area and transect models are not capable of simulating nitrate concentrations at individual wells; however, the transect model (which has more than twice the lateral resolution of the study-area model) has sufficient detail to approximately simulate the location of nitrate plumes.

The ground-water flow system was assumed to be at steady-state, meaning that the velocity and direction of ground-water flow did not change with time. Water-level variation occurs seasonally and over the long term in response to stresses like climatic variation. The variation can change the velocity, and possibly direction, of ground-water flow over periods ranging from hours to years depending on the cause; a change in river stage might affect the system for hours to days whereas an extended drought might have effects that last for months to years. These changes in the flow system could have effects on the fate and transport of nitrate not represented by the simulation models. The simulation models are designed to evaluate the long-term effects of options for management of nitrate loading. The models should not be used to evaluate short-term changes without considering the possible effects of changes in the ground-water velocity distribution from the steady-state conditions represented in the models.

The location of the boundary between the oxic and suboxic parts of the ground-water system was mapped based on dissolved oxygen concentrations in 256 wells sampled as part of a synoptic sampling of private wells by ODEQ and Deschutes County in June 2000. Because denitrification is assumed to occur at the oxic-suboxic boundary and nitrate concentration below the boundary (in the suboxic zone) is specified as zero, simulated nitrate concentrations near and below the boundary are sensitive to location. Uncertainty in the boundary location will result in uncertainty in simulated nitrate concentrations. The distribution of wells used to map the boundary was generally good for a study area this size, however, the boundary location is less certain in some areas. For example, there were fewer wells available to constrain the location of the boundary near the margin of the model area and near streams. In these areas, model results should be evaluated with respect to the effects of uncertainty on simulated nitrate concentrations. 
The ground-water discharge to evapotranspiration process is simulated by the study-area model and accounts for the mass of water lost from the system where deep-rooted plants extract ground water for transpiration and where ground water is shallow enough to be evaporated from bare soil. Plants also may take up nutrients dissolved in ground water; however, the rate of uptake is highly variable and poorly understood in non-agricultural settings. Nutrients and other solutes are not removed by evaporation and this process results in concentration of solutes in ground water. For this study, there was no basis for partitioning the mass of ground water discharged by ET into its transpiration and evaporation components and it was assumed that no nitrate was taken up with the mass of water discharged by ET. This assumption may bias simulated nitrate concentrations toward high values in areas where ET is a significant part of ground-water discharge.

\section{Management Model}

Because the NLMM was developed using optimization methods with the study-area simulation model, the NLMM is subject to the same limitations listed for the study-area model. However, additional factors should be considered when using the management model that relate to how the management problem is formulated.

The sensitivity analysis of the NLMM presented in this report illustrates how closely optimal solutions are tied to the definition of the management problem. The NLMM solutions were shown to be highly dependent on the value of the maximum nitrate concentration constraint and on the number, location, and depth of specified constraints. Assignment of the constraints is an important part of developing a strategy for protecting ground-water resources.

The management problem for this study was formulated with the objective of minimizing the amount of reduction in nitrate loading that would be required to meet specified water-quality goals within management areas. Management area boundaries were defined using the township and section lines of the Public Land Survey System (PLSS) and included areas ranging from 160 to 640 acres. The management-area boundaries do not coincide with the hydrologic, geologic, and geochemical boundaries that control the nitrate loading capacity of the system. The loading capacity for some management areas may be strongly controlled by loading in part of the area close to where constraints were specified. Large differences in computed optimal reduction requirements can occur across management-area boundaries even though there may be little difference in lot densities, recharge, depth of the suboxic zone, or other factors that affect loading capacity. Users of the NLMM need to be cognizant of the effects of problem formulation on results and interject knowledge of on-the-ground conditions when using model results to support management decisions.

\section{Summary and Conclusions}

Ground-water is an important resource in the rural communities of southern Deschutes and northern Klamath County, near La Pine, Oregon. The primary aquifer, and only source of drinking water to about 14,000 residents, comprises alluvial sand and gravel deposits within $100 \mathrm{ft}$ of land surface. Nearly 60 percent of residential lots are less than 1 acre and almost all homes use on-site wastewater disposal systems. Nitrate concentrations greater than the U.S. Environmental Protection Agency drinking water MCL of $10 \mathrm{mg} / \mathrm{L}$ were discovered in the oldest developed part of the area in the late 1970s and elevated concentrations have subsequently been detected in more recently developed areas. In 2000, nitrate concentrations greater than 4 mg N/L were detected in 10 percent of domestic wells sampled by Oregon Department of Environmental Quality. Because of concern for the vulnerability of the ground-water resource, the Oregon Department of Environmental Quality and Deschutes County, in cooperation with the U.S. Geological Survey, conducted a study to develop a better understanding of the hydrologic and chemical processes that affect the movement and fate of nitrogen within the shallow aquifers of the La Pine region. Simulation models were used to test the conceptual understanding of the system and were coupled with optimization methods to provide a management model that can be used to efficiently evaluate alternative approaches for managing nitrate loading from on-site wastewater systems.

The geologic, hydrologic, and geochemical frameworks for the conceptual and numerical models were developed using several data sources including previous hydrogeologic and water-quality studies in the area, an associated, largescale field experiment evaluating advanced treatment on-site wastewater systems, literature for similar studies in other areas, and extensive field data collection for this study.

The primary aquifer in the study area is composed of complexly interbedded fluvial silt, sand, and gravel deposits. A three-dimensional hydrofacies model of the fluvial system was created with transition probability geostatistical methods using parameters derived from analysis of two-dimensional lithologic sections and lithologic data from more than 400 drillers' logs. Five hydrofacies were included in the final model: clay-silt, sand, gravel, lacustrine clay-silt, and basalt. Mean annual ground-water recharge to the alluvial aquifer is $3.2 \mathrm{in} / \mathrm{yr}$, primarily from infiltration of precipitation and snowmelt. Ground-water discharges to streams, springs, and wells, and by evapotranspiration. The water-table generally is within 5-20 ft of land surface and varies seasonally over a range of a few feet in response to recharge and changing stream stage. 
On-site wastewater systems are the only significant source of anthropogenic nitrogen to shallow ground water in the study area. Low recharge rates and ground-water flow velocities have, for now, generally restricted nitrate occurrence to discrete plumes within 20-30 ft of the water table. Concentrations of nitrate typically are low in deeper, older ground water due to the nature and timing of nitrate loading and transport, and to loss by denitrification. Ground water in the study area evolves from oxic to increasingly reduced conditions with increasing depth below the water table. Suboxic conditions are achieved in 15-30 years, and the transition zone from oxic to suboxic ground water is narrow. Nitrate is denitrified near the oxic-suboxic boundary. Nitrate loading from residential, commercial, and other sources using on-site wastewater systems was estimated for 1960-99 using county building records, census data, monitoring data from field studies of on-site systems, and literature values. Adjusted for seasonal residency, residential loading estimates ranged from 12 to $14 \mathrm{lbs} / \mathrm{yr}$ per home between 1960 and 1999. During this period total nitrogen loading increased from 3,900 to $81,000 \mathrm{lb} / \mathrm{yr}$. Nitrogen loading increased by 17,000 to $98,000 \mathrm{lb} / \mathrm{yr}$ between 1999 and 2005 . When all approved lots are developed (projected to occur in 2019 at current building rates), nitrogen loading is estimated to reach nearly $150,000 \mathrm{lb} / \mathrm{yr}$.

Three-dimensional numerical simulation models were constructed at transect $\left(2.4 \mathrm{mi}^{2}\right)$ and study-area $\left(247 \mathrm{mi}^{2}\right)$ scales to simulate the fate and transport of nitrate within the shallow ground-water system. The transect model was used to test conceptual models at the site of a detailed geochemical investigation along a 3.5-mi long flow path within the study area. The study-area model was constructed at a scale appropriate as a planning tool for prediction of average nitrate concentrations in neighborhoods and subdivisions.

Calibration of the models was constrained by data that included measured heads, measured and estimated ground-water discharge to streams, time-of-travel estimated from chlorofluorocarbon age dates, and measured groundwater nitrate concentrations. Eight scenarios representing nitrate-loading management strategies were simulated for the 140-year period, 2000-2139. A base scenario was simulated which assumed existing and future homes would continue to use conventional on-site systems and nitrogen loading would reach the projected maximum of nearly $150,000 \mathrm{lb} / \mathrm{yr}$ in 2019 . Under this scenario, simulated nitrate concentrations continue to increase until the rate of nitrate loading to the aquifer system is balanced by nitrate losses to denitrification and ground-water discharge to the nearstream environment of the Deschutes and Little Deschutes Rivers. At equilibrium, average nitrate concentrations near the water table exceed $10 \mathrm{mg}$ N/L over areas totaling 9,400 acres. Other scenarios were simulated that evaluated the effects of reduced loading on water quality. Scenarios in which nitrate loading was reduced by 15-94 percent overall resulted in reductions of 22-99 percent in the area where average nitrate concentrations near the water table exceed $10 \mathrm{mg} \mathrm{N} / \mathrm{L}$ at equilibrium. Simulated ground-water ages agree with groundwater age data and show that the system is slow to respond to changes in nitrate loading due to low recharge rates and ground-water flow velocity. Consequently, reductions in nitrate loading will not immediately reduce average nitrate concentrations and the average concentration in the aquifer will continue to increase for 25-50 years depending on the amount and timing of loading reduction. The time required for average concentrations to decrease is, in part, also due to the assumption that replacement of existing on-site wastewater systems would take place over approximately 50 years.

Results of the scenario simulations showed that there is variable capacity to receive on-site wastewater system effluent. The capacity of an area to receive on-site wastewater system effluent is related to many factors, including the density of homes, presence of upgradient residential development, ground-water recharge rate, ground-water flow velocity, and thickness of the oxic part of the aquifer.

The study-area simulation model was used to develop a decision-support tool by incorporating optimization methods. The resulting model, the Nitrate Loading Management Model (NLMM), was formulated to minimize the reduction from estimated base scenario loading that would be needed to maintain ground-water nitrate concentrations or ground-water discharge of nitrate to streams below specified levels. The NLMM uses the response matrix approach to find the optimal (minimum) loading reductions in each of 97 management areas that will meet the specified water-quality constraints. The sensitivity of the optimal solutions (loading reductions) to water-quality and other constraints was evaluated by altering constraint values. The sensitivity of optimal solutions to constraints allows decision makers to assess tradeoffs between higher levels of water quality protection and the cost of reducing nitrate loading. The sensitivity analysis of the NLMM showed that optimal (minimum) loading reductions were most sensitive to the constraints on ground-water nitrate concentration in the shallow part of the oxic ground-water system, within 5-10 ft of the water table. 


\section{Acknowledgments}

We gratefully acknowledge the cooperation and assistance of the hundreds of residents of southern Deschutes and northern Klamath Counties who gave us permission to collect geologic and water-level data from their wells, allowed us access to their property, and provided other information that proved invaluable to this study. This study also benefited greatly from the dedicated efforts of many Deschutes County Community Development Department employees; special thanks go to Barbara Rich, Dan Haldeman, Catherine Morrow, Todd Cleveland, Peter Gutowsky, and Tim Berg. Oregon Department of Environmental Quality employees Bill Mason, Diane Naglee, Robert Bagget, and Dick Nichols, also provided valuable assistance during the study. Joe Miller, Nicholas Zerr, and Justin Rohrbaugh, all formerly of the U.S. Geological Survey, also are acknowledged for their valuable assistance in collecting and compiling data for this investigation.

\section{References Cited}

Ahlfeld, D.P., and Mulligan, A.E., 2000, Optimal management of flow in groundwater systems: San Diego, Calif., Academic Press, Inc., 185 p.

Allen, J.E., 1966, The Cascade Range volcanic-tectonic depression of Oregon, in Transactions of the Lunar Geological Field Conference, Bend, Oregon, August 1965: Oregon Department of Mineral Industries, p. 21-23.

Anderson, C.W., 2000, Framework for regional, coordinated monitoring in the middle and upper Deschutes River basins, Oregon: U.S. Geological Survey Open-File Report 00-386, $81 \mathrm{p}$.

Anderson, M.P., 1987, Field studies in groundwater hydrology-A new era: Reviews in Geophysics, v. 25, no. 2, p. 141-147.

Anderson, M.P., and Woessner, W.W., 1992, Applied groundwater modeling: San Diego, Calif., Academic Press, Inc., $381 \mathrm{p}$.

Bauer, H.H., and Vaccaro, J.J., 1987, Documentation of a deep percolation model for estimating ground-water recharge: U.S. Geological Survey Open-File Report 86-536, 180 p.

Boyd, T., 1996, Estimated recharge in the Upper Deschutes Basin: Portland, Oreg., Portland State University, M.S. thesis, $102 \mathrm{p}$.
Bower, H., and Rice, R.C., 1976, A slug test for determining hydraulic conductivity of unconfined aquifers with completely or partially penetrating wells: Water Resources Research, v. 12, p. 423-428.

Brutsaert, W.H., 1982, Evaporation into the atmosphereTheory, history, and applications: Dordrecht, Holland, D. Reidel Co., 299 p.

Carle, S.F., 1999, T-PROGS—Transition probability geostatistical software: Davis, Calif., University of California, $76 \mathrm{p}$.

Carle, S.F., and Fogg, G.E., 1996, Transitional probabilitybased indicator geostatistics: Mathematical Geology, v. 28, no. 4 , p. 453-476.

Carle, S.F., and Fogg, G.E., 1997, Modeling spatial variability with one- and multi-dimensional continuous Markov chains: Mathematical Geology, v. 29, no. 7, p. 891-917.

Carle, S.F., LaBolle, E.M., Weissman, G.S., VanBrocklin, D., and Fogg, G.E., 1998, Geostatistical simulation of hydrostratigraphic architecture-A transition probability / Markov approach in Concepts in hydrogeology and environmental geology: Society for Sedimentary Geology Special Publication, no. 2, p. 147-170.

Century West Engineering, 1982, La Pine aquifer management plan: Bend, Oreg., Century West Engineering, 597 p.

Cole, D.L., 2006, Groundwater quality report for the Deschutes basin, Oregon: Oregon Department of Environmental Quality Laboratory and Water Quality Division, 54 p., accessed July 2007 at http://www.deq.state. or.us/lab/techrpts/groundwater/dbgroundwater/dbgwreport. pdf

Couch, R., and Foote, R., 1985, The Shukash and La Pine Basins-Pleistocene depressions in the Cascades of Central Oregon [abs]: Eos Transactions of the American Geophysical Union, v. 66, no. 3, p. 24.

Daly, C., and Gibson, W., 2002, 103-year high-resolution precipitation climate data set for the conterminous United States: Corvallis, Oreg., Spatial Climate Analysis Service, accessed May 2002 at ftp://ftp.ncdc.noaa.gov/pub/data/ prism100/.

Fogg, G.E., 1986, Groundwater flow and sand body interconnectedness in a thick multiple aquifer system: Water Resources Research, v. 22, no. 5, p. 679-694. 
Frimpter, M.H., Donohue, J.J., and Rapacz, M.V., 1990, A mass-balance nitrate model for predicting the effects of land use on ground-water quality: U.S. Geological Survey OpenFile Report 88-493, 56 p.

Gannett, M.G., and Lite, K.E., 2004, Simulation of regional ground-water flow in the Upper Deschutes Basin, Oregon: U.S. Geological Survey Water Resources Investigations Report 03-4195, 84 p.

Gannett, M.W., Lite, K.E., Jr., Morgan, D.S., and Collins, C.A., 2001, Ground-water hydrology of the upper Deschutes Basin, Oregon: U.S. Geological Survey WaterResources Investigation Report 00-4162, 77 p.

Gettings, M.W., and Griscom, A., 1988, Gravity model studies of Newberry Volcano, Oregon: Journal of Geophysical Research, v. 93, p. 10,109-10,118.

Goode, D.J., and Konikow, L.F., 1990, Apparent dispersion in transient ground-water flow: Water Resources Research, v. 26 , no. 10 , p. $2,339-2,351$.

Gorelick, S.M., 1982, A model for managing sources of groundwater pollution: Water Resources Research, v. 18, no. 4 , p. $773-781$.

Gorelick, S.M., Freeze, R.A., Donohue, David, and Keely, J.F., 1993, Ground-water contamination-Optimal capture and containment: Boca Raton, Fla. Lewis Publishers, 385 p.

Gorelick, S.M., and Remson, I., 1982, Optimal management of groundwater pollutant sources: Water Resources Research, v. 18 , no. 1 , p. $71-76$.

Harbaugh, A.W., and McDonald, M.G., 1996, User's documentation for MODFLOW-96, an update to the U.S. Geological Survey modular finite-difference ground-water flow model: U.S. Geological Survey Open File Report 96-485, $56 \mathrm{p}$.

Herrero-Bervera, E., Helsley, C.E., Sarna-Wojcicki, A.M., Lajoie, K.R., Meyer, C.E., McWilliams, M.O., Negrini, R.M., Turrin, B.D., Donnelly-Nolan, J.M., and Liddicoat, J.C., 1994, Age and correlation of a paleomagnetic episode in the western United States by 40Ar/39Ar dating and tephrochronology_-The Jamaica, Blake, or a new polarity episode?: Journal of Geophysical Research, v. 99, p. 24,091-24,103.

Hinkle, S.R., Böhlke, J.K., Duff, J.H., Morgan, D.S., and Weick, R.J., 2007a, Aquifer-scale controls on the distribution of nitrate and ammonium in ground water near La Pine, Oregon, USA: Journal of Hydrology, v. 333, p. 486-503.
Hinkle, S.R., Morgan, D.S., Orzol, L.L., and Polette, D.J., 2007b, Ground water redox zonation near La Pine, Oregon-Relation to river position within the aquiferriparian zone continuum: U.S. Geological Survey Scientific Investigations Report 2007-5239, 30 p.

Hinkle, S.R., Weick, R.J., Johnson, J.M., Cahill, J.D., Smith, S.G., and Rich, B.J., 2005, Organic wastewater compounds, pharmaceuticals, and coliphage in ground water receiving discharge from onsite wastewater treatment systems near $\mathrm{La}$ Pine, Oregon-Occurrence and implications for transport: U.S. Geological Survey Scientific Investigations Report 2005-5055, 98 p.

Hutton, S.S., Barber, N.L., Kenny, J.F., Linsey, K.S., Lumia, D.S., and Maupin, M.A., 2004, Estimated use of water in the United States in 2000: U.S. Geological Survey Circular 1268,46 p.

Johnson, N.M., and Dreiss, S.J., 1989, Hydrostratigraphic interpretation using indicator geostatistics: Water Resources Research v. 25, no. 12, p. 2501-2510.

Jones, Lesley, 2003, Characterization of select water quality parameters within the upper Deschutes and Little Deschutes study areas: Upper Deschutes Watershed Council Bend, Oregon: 2003, 127 p.

LINDO Systems, Inc., 2003, What's best! User's manual: Chicago, Ill, LINDO Systems Inc., 291 p.

Lite, K.E., and Gannett, M.W., 2002, Geologic framework of the regional ground-water flow system in the Upper Deschutes Basin, Oregon: U.S. Geological Survey WaterResources Investigations Report 02-4015, 44 p.

Lohman, S.W., 1972, Ground-water hydraulics: U.S. Geological Survey Professional Paper 708, 70 p.

MacLeod, N.S., and Sherrod, D.R., 1992, Reconnaissance geologic map of the west half of the Crescent 1 degree by 2 degrees Quadrangle, central Oregon: U.S. Geological Survey Miscellaneous Investigations Map I-2215, scale $1: 250,000$.

MacLeod, N.S., Sherrod, D.R., Chitwood, L.A., and Jenson, R.A., 1995, Geologic map of the Newberry volcano, Deschutes, Klamath, and Lake Counties, Oregon: U.S. Geological Survey Miscellaneous Investigations Map I-2455, scales 1:62,500 and 1:24,000.

Moosburner, G.J., and Wood, E.F., 1980, Management model for controlling nitrate contamination in the New Jersey Pine Barrens aquifer: Water Resources Bulletin, v. 16, no. 6, p. 971-978. 
Oregon Department of Environmental Quality, 1994, Statewide groundwater monitoring program, La Pine area groundwater investigation, Deschutes County, Oregon: Portland, Oreg, Oregon Department of Environmental Quality, v. II, variously paginated.

Oregon Department of Environmental Quality, 2004a, La Pine demonstration project fact sheet: Oregon Department of Environmental Quality, 2 p.

Oregon Department of Environmental Quality, 2004b, Water Quality_La Pine demonstration project: Oregon Department of Environmental Quality, accessed May 2004, at http://www.deq.state.or.us/wq/lapine/siterptcriteria.asp

Oregon Department of Human Services, 2005, Drinking water program-Inventory list for all drinking water systems: Oregon Department of Human Services, accessed October 7, 2005, at http://170.104.158.45/index.html

Pollock, D.W., 1994, User's Guide for MODPATH/ MODPATH-PLOT, v. 3-A particle tracking postprocessing package for MODFLOW, the U.S. Geological Survey finite-difference ground-water flow model: U.S. Geological Survey Open-File Report 94-464, 248 p.

Robinson, T.W., 1958, Phreatophytes: U.S. Geological Survey Water-Supply Paper 1423, 85 p.

Sherrod, D.R., and Pickthorn, L.G., 1989, Some notes on Neogene structural evolution of the Cascade range in Oregon, in Muffler, L.J.P., Weaver, C.S., and Blackwell, D.D., eds., Geology, geophysics, and tectonic setting of the Cascade Range: U.S. Geological Survey Open-File Report 89-178, p. $351-368$

Tchobanoglous, G., and Burton, F.L., 1991, Wastewater engineering-Treatment, disposal, and reuse, 3rd ed.: Metcalf \& Eddy, Inc., New York, McGraw-Hill, Inc.

U.S. Bureau of the Census, 1960, Profile of selected housing characteristics - 1960, geographic area, Table DP-1, La Pine, Oregon: U.S. Bureau of the Census, accessed (2001) at http://quickfacts.census.gov/qfd/.

U.S. Bureau of the Census, 1970, Profile of selected housing characteristics - 1970, geographic area, Table DP-1, La Pine, Oregon: U.S. Bureau of the Census, accessed (2001) at http://quickfacts.census.gov/qfd/.
U.S. Bureau of the Census, 1980, Profile of selected housing characteristics - 1980, geographic area, Table DP-1, La Pine, Oregon: U.S. Bureau of the Census, accessed (2001) at http://quickfacts.census.gov/qfd/.

U.S. Bureau of the Census, 1990, Profile of selected housing characteristics - 1990, geographic area, Table DP-1, La Pine, Oregon: U.S. Bureau of the Census, accessed (2001) at http://quickfacts.census.gov/qfd/.

U.S. Bureau of the Census, 2000, Profile of selected housing characteristics - 2000, geographic area, Table DP-1, La Pine, Oregon: U.S. Bureau of the Census, accessed (2001) at http://quickfacts.census.gov/qfd/.

U.S. Environmental Protection Agency, 1980, Onsite wastewater treatment and disposal systems design manual: Cincinnati, Ohio, U.S. Environmental Protection Agency report EPA-625/1-80-012, 391 p.

U.S. Environmental Protection Agency, 1994, Ground-water modeling compendium, 2nd ed.: U.S. Environmental Protection Agency report 500-B-94-004, 175 p.

Vorhis, R.C., 1979, Transmissivity from well data: National Water Well Association, Well Log, v. 10, no. 11, p. 50-52.

Weissmann, G.S., Carle, S.F., and Fogg, G.E., 1999, Threedimensional hydrofacies modeling based on soil surveys and transitional probability geostatistics: American Geophysical Union, Water Resources Research, v. 35, no. 6, p. 1761-1770.

Winter, T.C., LaBaugh, J.W., and Rosenberry, D.O., 1988, The design and use of a hydraulic potentiomanometer for direct measurement of differences in hydraulic head between groundwater and surface water: Limnology and Oceanography, v. 33, no. 5, p. 1209-1214.

Zdanowicz, C.M., Zielinski, G.A., and Germani, M.S., 1999, Mount Mazama eruption-Calendrical age verified and atmospheric impact assessed: Geology, v. 1999, no. 27, p. 621-624.

Zheng, C., and Bennett, G.D., 1995, Applied contaminant transport modeling - Theory and practice: New York, John Wiley and Sons, $656 \mathrm{p}$.

Zheng, C., and Wang, P.P., 1999, MT3DMS-A modular three-dimensional multispecies transport model (release DoD_3.50.A) Documentation and User's Guide: U.S. Army Corps of Engineers, Contract Report SERDP-99, 220 p. 
This page intentionally left blank. 


\section{Appendix A. Vertical Hydraulic Head Gradient Data from Measurements Made on the Deschutes and Little Deschutes Rivers, in the La Pine, Oregon, Study Area, October 23- November 4, 2000.}

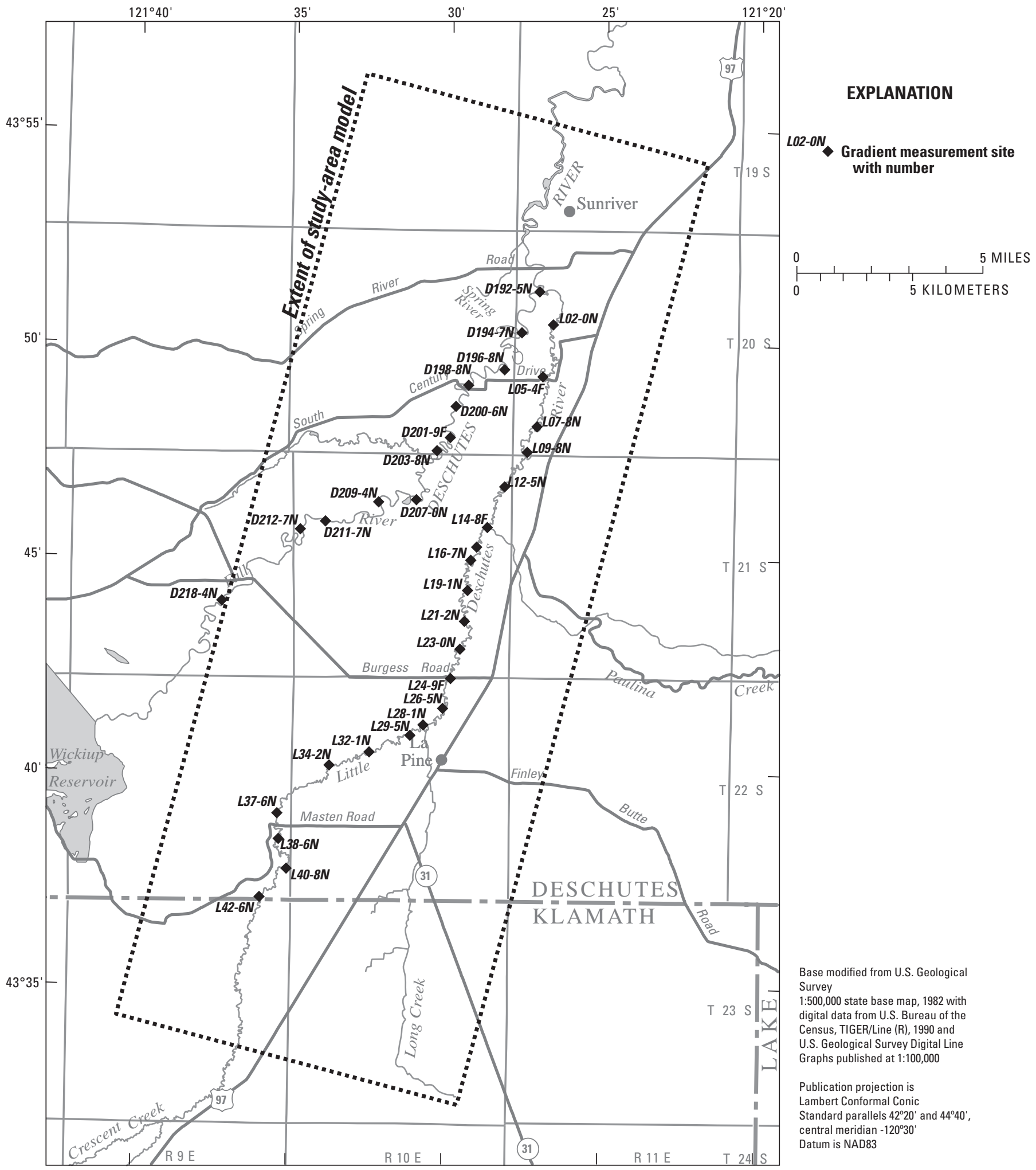

Figure A1. Locations of vertical head gradient measurement sites in the La Pine, Oregon, study area. 


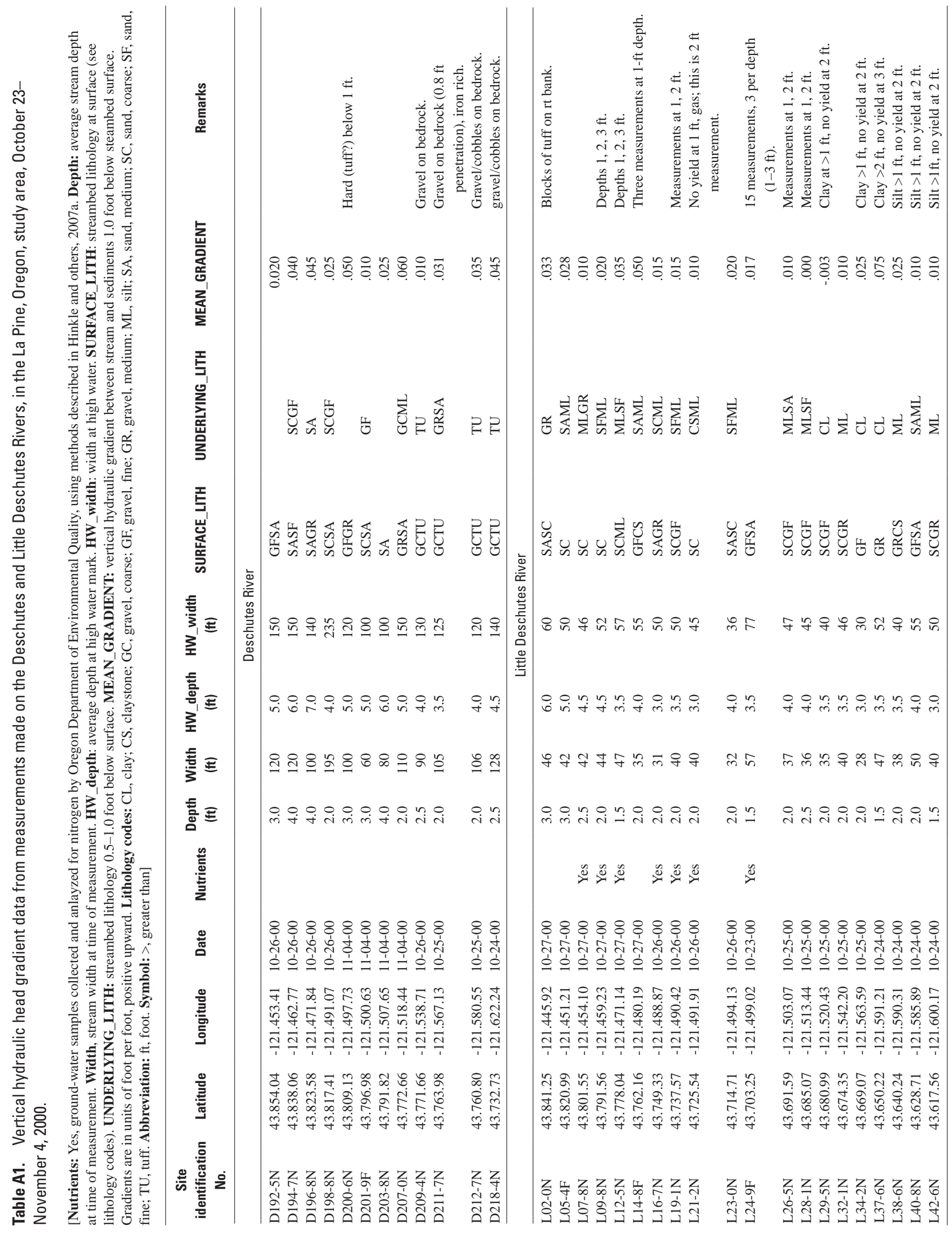


Manuscript approved for publication, September 29, 2007

Prepared by the USGS Publishing Network,

Publishing Service Center, Tacoma, Washington

Bob Crist

Bill Gibbs

Debra Grillo

Jackie Olson

Bobbie Jo Richey

Sharon Wahlstrom

For more information concerning the research in this report, contact

Director, Oregon Water Science Center

U.S. Geological Survey, 2130 SW 5th Avenue

Portland, Oregon 97201

http://or.water.usgs.gov 
